\title{
Does Democracy Cause Growth? A Meta-Analysis (of 2000 Regressions)
}

\author{
Marco Colagrossi ${ }^{\mathrm{a}}$, Domenico Rossignoli ${ }^{\mathrm{b}, *}$, Mario A. Maggioni ${ }^{\mathrm{b}}$ \\ ${ }^{a}$ CSCC, Università Cattolica del Sacro Cuore, Milano \\ ${ }^{b}$ DISEIS and CSCC, School of Political and Social Science, Università Cattolica del Sacro Cuore, \\ Milano
}

\begin{abstract}
The relationship between democracy and economic growth has been widely debated in the social sciences with contrasting results. We apply a meta-analytical framework surveying 188 studies (2047 models) covering 36 years of research in the field. We also compare the effect of democracy on growth with the effect of human capital on growth in a sub-sample of 111 studies (875 models). Our findings suggest that democracy has a positive and direct effect on economic growth beyond the reach of publication bias, albeit weaker (about one third) of that of human capital. Further, the growth effect of democracy appears to be stronger in more recent papers not surveyed in Doucouliagos \& Ulubaşoğlu (2008). Finally, we show that the heterogeneity in the reported results is mainly driven by spatial and temporal differences in the samples, indicating that the democracy and growth nexus is not homogeneous across world regions and decades.

Keywords: Democracy, Economic Growth, Human Capital, Meta-Analysis JEL: C83, P16, O10
\end{abstract}

\footnotetext{
${ }^{*}$ Corresponding author: domenico.rossignoli@unicatt.it
} 


\section{Introduction}

The relationship between democracy and economic growth has been the subject of a vast literature in the social sciences with contrasting results. Researchers adopting a variety of identification strategies, estimation techniques and different samples of countries and periods have claimed either a positive (e.g. Acemoglu et al., 2019; Gründler \& Krieger, 2016; Madsen et al., 2015) or a negative (e.g. Przeworski, 2000; Gerring et al., 2005) or a non-significant relationship (e.g. Baum \& Lake, 2003; Murtin \& Wacziarg, 2014).

Early empirical investigations of the institutional determinants of economic growth (e.g. Barro, 1991; Barro \& Sala-i-Martin, 1992) already showed mixed findings. However, this is not surprising: as Sala-i-Martin (1997) noted, economic growth theories are usually not explicit in stating which are the factors that matter most for a country to prosper. Therefore, despite the accumulation of empirical evidence, the consensus among scholars on this issue was far from being reached. As Sirowy \& Inkeles stated "many of the central questions pertaining to the developmental consequences of political democracy remain, by and large, unresolved"; furthermore, "the relevant quantitative, cross-national research continues to be plagued by conflicting findings" (Sirowy \& Inkeles, 1990, p. 127). A few years later, similar conclusions were reached by Przeworski \& Limongi: when it comes to the nexus between democratic institutions and economic development "social scientists know surprisingly little" (Przeworski \& Limongi, 1993, p. 51).

In an effort to solve this puzzle, further attempts moved their focus mostly on identification strategies, proposing alternative solutions to the embedded endogeneity of institutions (e.g. Acemoglu et al., 2001). This led to a further diversification of model specifications, estimation techniques and even measures of democracy. Such 
process led to a tentative consensus for a positive effect of democracy on growth among economists (Acemoglu et al., 2019). However, despite the democracy and growth conundrum benefited from renewed attention - and from the introduction of novel econometric techniques, machine learning algorithms for pattern recognition and new measures of democracy - the key question remained somehow unaddressed (Gerring et al., 2005; Knutsen, 2012). Finally, the recent increase in empirical evidence in economics supporting the causal link from democracy to economic growth is yet contrasted by a few papers claiming that democracy follows the increase in income (e.g. Gundlach \& Paldam, 2009; Murtin \& Wacziarg, 2014).

Doucouliagos \& Ulubaşoğlu (2008) delved into the debate by performing the first meta-analysis on the issue based on a sample of 483 point-estimates included in 84 studies. They concluded that "democracy does not have a direct impact on economic growth. However, it has robust, significant and positive indirect effects through higher human capital, lower inflation, lower political instability and higher economic freedom" (Doucouliagos \& Ulubaşoğlu, 2008, p. 61). This conclusion supported earlier evidence provided by Tavares \& Wacziarg (2001) and spurred further research (such as, for instance, Gründler \& Krieger, 2016; Dahlum \& Knutsen, 2017; Acemoglu et al., 2019).

Our contribution to this debate follows Doucouliagos \& Ulubaşoğlu (2008) and takes advantage of the increased production of quantitative scientific papers on the topic as well as advances in meta-analytical techniques. We collect all point estimates available in both published and unpublished studies and find no evidence of publication bias in this literature. ${ }^{1}$ We then address the effect sizes' hierarchical dependence (Stevens \& Taylor, 2009) - through multilevel modelling and clustering techniques

\footnotetext{
${ }^{1}$ Please refer to Table A.1 for a detailed classification of Published and Unpublished works.
} 
- and assess the robustness of our findings against a variety of specifications and estimators.

Finally, we collect all point estimates relating to human capital included in our sample of studies. Human capital is a widely accepted key factor in the process of economic growth and "a significant amount of research has been devoted to the education-growth nexus" (Benos \& Zotou, 2014, p. 669) in both the neoclassical and the endogenous growth literature; furthermore, several attempts investigating a causal mechanism of transmission of democracy on growth focus on human capital (e.g. Saint-Paul \& Verdier, 1993; Tavares \& Wacziarg, 2001; Dahlum \& Knutsen, 2017). By comparing the strength of the association between democracy and growth with the magnitude of the effect of human capital on growth, we provide a direct comparison to support the interpretation of the results of our meta-analysis. ${ }^{2}$

In brief, the novel contribution of this paper is threefold. First, we collect the largest and most up-to-date sample of studies investigating the democracy and growth nexus, consisting of 188 papers and 2047 effect sizes; second, we provide a comparison between the estimated effect of democracy on economic growth with the effect, on growth, of human capital; third, we show that the growth effect of democracy appears to be stronger in more recent papers not surveyed in Doucouliagos \& Ulubaşoğlu (2008).

The rest of the paper is organised as follows: Section 2 provides a survey of the main issues in the democracy and growth literature; Section 3 outlines the procedures followed to collect the sample of studies providing descriptive evidence and discusses the methodology; Section 4 provides results and findings of both meta-analysis and

\footnotetext{
${ }^{2}$ It shall be acknowledged that, while the estimation of the effect of human capital on growth is comparable with that of democracy on growth, our result can not be interpreted as a meta-analysis on the education-growth nexus. For the latter, see Benos \& Zotou (2014).
} 
meta-regression analysis as well as predicted values from our preferred specification of the effect of democracy on growth. Further, it discusses the issue of publication bias; finally, Section 5 concludes the paper.

\section{The democracy and growth conundrum}

Despite an initial fierce debate on the role of institutions in determining individual economic behaviour and aggregate performance, starting in the 1990s, economists widely acknowledged that "institutions matter" for long-run growth (North, 1994).

Institutions can be defined as "humanly devised constraints that structure political, economic and social interactions" (North, 1990, p. 97) or as "systems of established and embedded social rules that structure social interactions" (Hodgson, 2006, p. 13). Therefore, institutions may influence the incentive structure by affecting the underlying economic context, potentially fostering or curbing the dynamics of economic activity.

Much of the existing empirical literature on this issue implemented the analysis of the impact of democracy on economic growth through the adoption of indices of political regimes. Such tradition dates back to the seminal comparative study of Lipset (1959). Notwithstanding the vast amount of empirical research spurred on the topic, results were still contrasting and inconclusive. ${ }^{3}$ One of the main empirical challenges concerned how to quantify the degree of democracy in a country. Over the years, several approaches have been proposed: interval-level or dichotomous variables, both based on experts' panels, procedural algorithms and, more recently, machine-

\footnotetext{
${ }^{3}$ As an example, Przeworski (2000) shows that though the direct relationship is quite inconclusive, dictatorships tend to allocate capital more efficiently, while democracies (in high-income countries) produce more output per capita. Studies focusing on levels of democracy (rather than regime transitions) identified either negative but not significant (Helliwell, 1994) or negative and slightly significant (Barro, 1996) or inverse-U shaped relationships with low or no statistical significance (Barro, 2003).
} 
learning techniques.

The meta-analysis by Doucouliagos \& Ulubaşoğlu (2008) documented a positive and significant coefficient of democracy in $27 \%$ of the cases, while in $37 \%$ it was positive but not significant and in 36\% it was either negative or negative and not significant (Doucouliagos \& Ulubaşoğlu, 2008, p. 62). In the same study, the authors suggested that other factors (e.g. human capital, inflation, political instability, etc.) possibly act as channels of transmission between democracy and growth.

Przeworski \& Limongi (1993) and Knutsen (2011) focused on democratic institutions as a means to guarantee property rights, while Barro (1991), Przeworski \& Limongi (1993) and Olson (1993) considered the ability of democratic institutions to assist production and maximise the total output by guaranteeing private activity or stimulating it by directly supplying inputs. Minier (1998) explored the possibility of a productivity-enhancing role of democracy, driven by a more efficient allocation of production factors compared to autocratic regimes. Rodrik \& Wacziarg (2005) found that the process of democratisation exerts a positive effect on growth, whose heterogeneity depends on the consolidation of democracy itself. Klomp \& de Haan (2009) stressed that good political institutions are expected to favour growth by limiting volatility. Gerring et al. (2005) emphasised the role played by political capital, as a result of the stock of democratic experiences accumulated by a country.

Conversely, other scholars perceived the relationship between development and political democracy as conflicting or even incompatible: voters' interest "generally leads parties to give the expansion of personal consumption a higher priority visà-vis investment than it would receive in a nondemocratic system." (Huntington \& Dominguez, 1975, p. 60). Democracy and economic growth are considered to be competing concerns, as Sirowy notes that "successful and rapid economic growth requires an authoritarian regime" (Sirowy \& Inkeles, 1990, p. 129). Further, Olson (1982) pos- 
tulated that in democratic regimes special-interest groups' actions, aiming at rents, ultimately lead to an institutional sclerosis of the political and economic system, generating stagnation and fostering political instability. Following Przeworski \& Limongi (1993), the essential dynamics through which democracy is believed to hamper growth refer to political pressures for immediate consumption, reducing investments. Furthermore, whereas there is agreement on the benefits of securing property rights, it is controversial whether autocracies can better secure these rights (Przeworski \& Limongi, 1993). Finally, authoritarian regimes can be more effective in timely implementing the kinds of policies reputed necessary to boost growth while "democratic regimes are largely unable to implement effectively the kinds of policies considered necessary to facilitate rapid growth" (Sirowy \& Inkeles, 1990, p. 129).

The abundance of different and contrasting results about the democracy-growth nexus can be explained by a number of alternative reasons. Firstly, since democracy is a multidimensional concept that cannot be directly observed and uniquely quantified, its definition as well as the measurement of its components (and how they are aggregated) are crucial in determining the sign and significance of its coefficient(s). Secondly, studies aimed at testing the causal effect of democracy on growth, are based on a large set of model specifications and estimation techniques that can affect the outcome of the analysis (see Gründler \& Krieger, 2016, for a detailed discussion on both issues.) Overall, the presence of a large number of alternative hypotheses, specifications and contrasting results allows for applying a meta-analytical framework in which the effect of these features on the estimated relationship can be controlled and accounted for. 


\section{The meta-analytic framework}

\subsection{Procedures}

The validity of a meta-analysis highly depends on the search conducted to retrieve the articles that form the sample of studies from which inference will be drawn (Hopewell et al., 2005). Our last search was conducted on April 2019 and involved a four-step approach. First, we run the query "democracy AND growth" over five academic databases - Econlit, Jstor, RePEc, ScienceDirect and SSRN. ${ }^{4}$ We then investigated nine qualitative literature reviews on the topic of democracy and growth. ${ }^{5}$ Then, we moved towards a forward snowballing sampling approach. We identified four among the most cited papers investigating the democracy and growth nexus in the last four decades (Weede, 1983; Barro, 1996; Acemoglu et al., 2008, 2019) and searched, through the Google Scholar citation system, for articles quoting them. Finally, we integrated our sample of papers with those contained in the meta-analysis by Doucouliagos \& Ulubaşoğlu (2008).

To be included in our sample, studies must contain a coefficient of democracy and a measure of its dispersion (typically the t-statistic or the standard error) in a regression framework where a proxy of economic growth is the dependent variable. ${ }^{6}$ To compare the magnitude (and the direction) of the effect of democracy on economic growth with a meaningful benchmark, we also collected (when available) the coefficient of

\footnotetext{
${ }^{4}$ Precisely, we searched for the words "democracy AND growth" as well as "democracy AND income". The search was not circumscribed to the article title but covered also its keywords and abstracts. Importantly, the databases we employed use search algorithms that diversify the search terms using passive forms, singular, plurals and synonyms of the words used.

${ }^{5}$ Namely Przeworski \& Limongi (1993); Alesina \& Perotti (1994); Brunetti (1997); Heo \& Tan (2001); Rivera-Batiz (2002); Gerring et al. (2005); Kong (2007); Hazama (2008); Knutsen (2012).

${ }^{6}$ Importantly, studies investigating the impact of regime transitions on economic growth are not included in our sample, since both their aims and methodologies are not comparable to those of the democracy and growth literature. While the latter try to assess the impact of the level and/or the presence of democracy on economic growth, the former investigate how regime transitions (usually the democratisation process) impact the growth trajectory of countries.
} 
human capital and a measure of its dispersion.

Concerning publication status, Doucouliagos \& Ulubaşoğlu (2008) choose not to include working papers and unpublished articles to control for research quality. We instead agree with Stanley, who argues that "differences in quality, data or methods do not provide a valid justification for omitting studies" (Stanley, 2001, p. 135): rather such differences provide the rationale for performing a meta-analysis and a meta-regression analysis (MRA) in the first place. Thus, potential differences arising from different publication status can always be investigated in an MRA setting.

To avoid the artificial reduction of the heterogeneity of the collected effect sizes, we did not discriminate between what authors indicate as their "best specification" and other models; instead, we collected all available estimates included in each study. To assess the robustness of our results, we collected information on whether the coefficient was part of a model considered by the author(s) as a sensitivity analysis, robustness test, placebo or falsification strategy and/or was included in the Appendix. We considered everything else as main specifications.

Further, we also included in our sample specifications reporting interaction or quadratic form terms of the independent variable(s) of interest. We do acknowledge, as Gunby et al. (2017) show, that in such specifications the estimated coefficients of democracy (or human capital) might provide biased information about the marginal effect of democracy (human capital) on economic growth. In fact, in a non-linear specification such as $y=\beta_{0}+\beta_{1} x+\beta_{2} x^{2}$, the marginal effect $\partial y / \partial x$ is equal to $\beta_{1}+$ $2 \times \beta_{2} \times x$. Similarly, when the specification includes an interaction term so that $y=\beta_{0}+\beta_{1} x+\beta_{2} x \times z+\beta_{3} z$, the marginal effect $\partial y / \partial x$ is equal to $\beta_{1}+\beta_{2} z$. However, it is always possible to exclude these models in a meta-analysis or to control for the fact that they were collected in a non-linear specification (or in a specification where they were part of an interaction term) in an MRA through dummy variables. 
We did exclude studies reporting only Granger causality tests, as they usually do not report, for the same specification, a single estimate of the relationship between democracy and economic growth, but rather several lags of it. Finally, we investigated only articles written in English, the lingua franca of the international scientific community, in which data were collected from 1945 onward.

Overall, the process yielded $2047 \beta_{\text {dem }}$ (democracy) estimates in 188 papers and $875 \beta_{h c}$ (human capital) estimates in 111 papers. $^{7}$ We then created a reduced sample to investigate the effect of democratic institution on economic growth when human capital is accounted for. It contains 111 papers for a total of 764 effect sizes. ${ }^{8}$ Further we created two sub-sample based on publication dates, the threshold being December 2005 (the date of the last search performed by Doucouliagos \& Ulubaşoğlu (2008) (henceforth DU). The pre-DU sample contains 741 effect sizes clustered around 94 studies, while the post-DU sample shows 1306 effect sizes included in 94 studies. Finally, to test the sensitivity of our results to authors' robustness tests, we created a sample (main specifications sample) including only the main specifications reported in each article. It includes 180 studies and 1227 effect sizes.

The number of estimates varies widely across studies. In the full sample, it ranges from 1 to 90 with a mean of 10.89 estimates per study. In 17 cases, studies report only 1 estimate matching our criteria, while in 9 cases only we collected more than 50 coefficients. The earliest article in our sample was published in 1983 while the latest in 2019, covering more than 35 years of literature on the topic of democratic institutions and economic growth. Of such articles, 10 have been published in the

\footnotetext{
${ }^{7}$ References and additional information regarding our sample are provided in Appendix A.

${ }^{8}$ The number of effect sizes diverge from the full sample of human capital estimates as it is common in the literature to include more than one proxy of human capital (e.g. separate enrolment ratios for males and females). Therefore, while there are a total of $875 \beta_{h c}$ estimates, there are only 764 democracy-related betas.
} 
80s, 48 in the 90s, 55 from 2000 to 2009 and 75 from 2010 onward. With regard to publication status, 150 studies are published in an academic journal recognised either by the RePEc (Research Papers in Economics) database or by the SCImago Journal \& Country Rank portal. 26 are working papers whose series are included in the RePEc WPS (Working Paper Series) database. Finally, 3 are books (or book chapters) and 9 papers either do not report any source or their source is recorded neither in RePEc nor in SCImago.

\subsection{Effect sizes and descriptives}

The adopted effect size is the partial correlation coefficient, as commonly done in recent meta-analysis in economics (e.g. Iwasaki \& Tokunaga, 2014; Dauvin \& Guerreiro, 2017; Gunby et al., 2017). It estimates the degree of association between the dependent variable and the independent variable when the other variables included in the model are held constant. ${ }^{9}$ It has the benefit of allowing the comparison and the synthesis of the collected estimates when different independent variables, with different scales and definitions, are used. ${ }^{10}$ The partial correlation coefficient is then

\footnotetext{
${ }^{9}$ Seven models do not include independent variables other than the measure of democracy. Therefore, correlations computed from these models are not partial correlations but rather zero-order correlations, which might suffer from severe identification problems. Table B.2 and Table B.10 test the robustness of the findings discussed in Section 4 to the exclusion of these effect sizes. Results are substantially unchanged. We thank an anonymous reviewer for driving our attention to this issue.

${ }^{10}$ The partial correlation coefficient is computed as:

$$
r_{f}=\frac{t_{f}}{\sqrt{t_{f}^{2}+d f}}
$$

where $t_{f}$ is the $t$ statistic of the regression coefficient $\beta_{f}$ while $d f$ is the degrees of freedom $(n-p-1)$ in which $p$ is the number of regressors and $n$ is the number of observations. Its sample variance is instead given by:

$$
\operatorname{var}\left(r_{f}\right)=\frac{\left(1-r_{f}^{2}\right)^{2}}{d f}
$$


normalised using the Fisher's z-score transformation. ${ }^{11}$

We begin our analysis documenting the distribution of Fisher's Z scores. Table 1 provides a first outlook to the accumulated evidence on the relationship between democracy, human capital and growth. ${ }^{12}$ The majority of the effect sizes recorded in the full sample are non-significant while about $1 / 3$ are positive and significant. On the contrary, in the sample of papers including both measures of democracy and human capital as determinants of growth, the effect of human capital is positive and significant in $2 / 5$ of the cases, while the effect of democracy is positive in $1 / 4$ of the cases and negative in almost $1 / 5$ of the cases.

There are no sizeable differences if we consider either main specifications or the full sample. On the contrary, differences arise once comparing the pre-DU and post$D U$ samples. The positive effect sizes increase from $1 / 4$ to $2 / 5$ from the pre- $D U$ to the post- $D U$ sub-sample. Further, there is a 10 percentage points reduction in the non-significant estimates after December 2005. Whether these results are due to the advancement in econometric techniques or to the use of better measures of democracy cannot be discerned due to limited data availability. ${ }^{13}$

We now move to the visual investigation of our samples. The forest plot of the

${ }^{11}$ The Fisher's z-score transformation is equal to:

$$
z=\frac{1}{2} \ln \left(\frac{1+r_{f}}{1-r_{f}}\right)
$$

with a sampling variance of:

$$
\operatorname{var}(z)=\frac{1}{n-3}
$$

${ }^{12}$ The density plots showing the distribution of the t-statistics for both samples can be found in Appendix C, Figures C.1a and C.1b. Table C.1 shows that the results of Table 1 are robust to the adoption of the t-statistics.

${ }^{13}$ Indeed (at least) two new measures of democracy have been released over the last few years, namely the Support Vector Machine Democracy Index (Gründler \& Krieger, 2016, 2018) and the set of democracy indicators provided by the V-Dem project (see https://www.v-dem.net/), but their use, although rapidly increasing, is still limited in the literature to allow for a further investigation. 
Table 1: Democracy, human capital, and growth: Fisher's Z score

\begin{tabular}{|c|c|c|c|c|}
\hline & Positive & Negative & Non-significant & Total \\
\hline \multicolumn{5}{|l|}{ Democracy } \\
\hline effect sizes & 711 & 242 & 1094 & 2047 \\
\hline & $34.73 \%$ & $11.82 \%$ & $53.44 \%$ & \\
\hline studies & & 20 & 120 & 188 \\
\hline & $25.53 \%$ & $10.64 \%$ & $63.83 \%$ & \\
\hline \multicolumn{5}{|l|}{ Human Capital } \\
\hline effect sizes & 352 & 29 & 494 & 875 \\
\hline & $40.23 \%$ & $3.31 \%$ & $56.46 \%$ & \\
\hline studies & 39 & 2 & 70 & 111 \\
\hline & $35.14 \%$ & $1.80 \%$ & $63.06 \%$ & \\
\hline \multicolumn{5}{|l|}{ Democracy (Reduced) } \\
\hline effect sizes & 197 & 152 & 415 & 764 \\
\hline & $25.79 \%$ & $19.90 \%$ & $54.32 \%$ & \\
\hline studies & 21 & 14 & 76 & 111 \\
\hline & $18.92 \%$ & $12.61 \%$ & $68.47 \%$ & \\
\hline \multicolumn{5}{|l|}{ Democracy (Main specifications) } \\
\hline effect sizes & 393 & 157 & 677 & 1227 \\
\hline & $32.03 \%$ & $12.80 \%$ & $55.18 \%$ & \\
\hline studies & & 20 & 113 & 180 \\
\hline & $26.11 \%$ & $11.11 \%$ & $62.78 \%$ & \\
\hline \multicolumn{5}{|l|}{ Democracy (Pre-DU) } \\
\hline effect sizes & 181 & 114 & 446 & 741 \\
\hline & $24.43 \%$ & $15.38 \%$ & $60.19 \%$ & \\
\hline study & 21 & 8 & 65 & 94 \\
\hline & $22.34 \%$ & $8.51 \%$ & $69.15 \%$ & \\
\hline \multicolumn{5}{|l|}{ Democracy (Post-DU) } \\
\hline effect sizes & 530 & 128 & 648 & 1306 \\
\hline & $40.58 \%$ & $9.80 \%$ & $49.62 \%$ & \\
\hline studies & 27 & 12 & 55 & 94 \\
\hline & $28.72 \%$ & $12.77 \%$ & $58.51 \%$ & \\
\hline
\end{tabular}

Notes: The significance level is $\mathrm{p}<0.05$. The Reduced sample contains only estimates of democracy collected from a specification in which a proxy of human capital was included. The pre- $D U$ sample contains only estimates collected from studies published before December 2005 - the date in which the search for studies by Doucouliagos \& Ulubaşoğlu (2008) ended. The post-DU sample contains instead only estimates collected from studies published after December 2005. The main specifications sample contains only estimates collected from specifications included in the body of the article (i.e. appendixes are excluded) and not labelled as robustness tests, sensitivity analyses or falsification and/or placebo strategies. 
Figure 1: Forest plots: average effect size (Fisher's Z) per study and 95\% confidence interval.

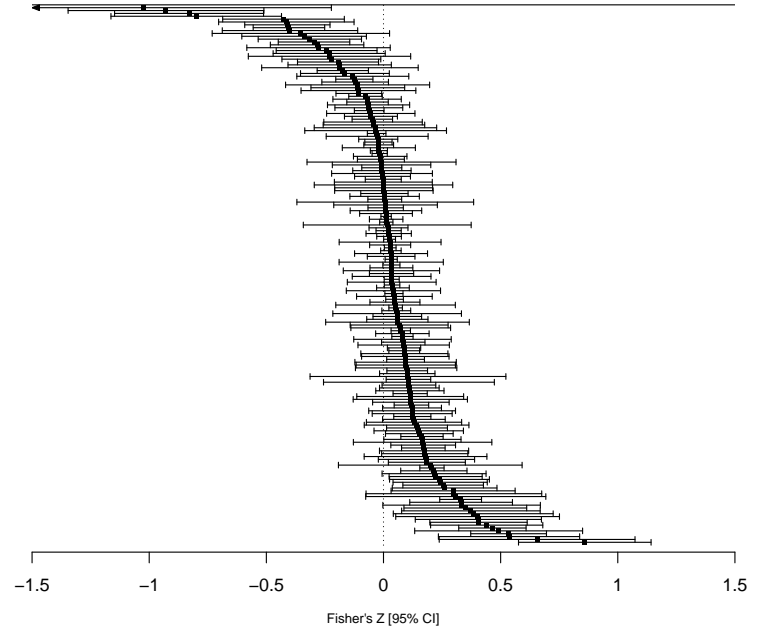

(a) Democracy and economic growth

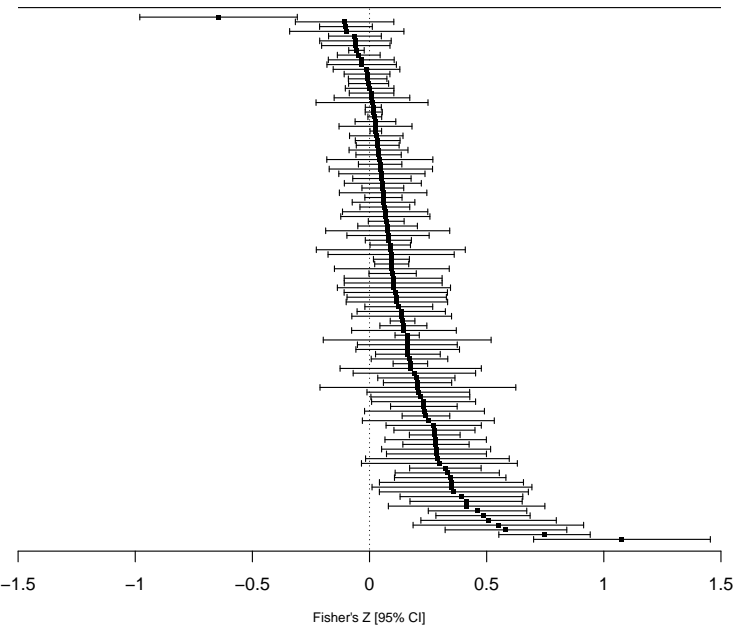

(b) Human capital and economic growth

Note: in Figure 1a, axis are limited to the $[-1.5 / 1.5]$ interval.

relationship between democracy and economic growth (Figure 1a) shows that most of the studies report (on average) null effect-sizes (not significantly different from 0); it is interesting to note how the strictly positive effects and the strictly negative effects almost counterbalance. Instead, the collected effect sizes of the impact of human capital on growth (Figure 1b) exhibit a rather different pattern. The majority of them cross the line of null effect similarly to the democracy-growth estimates; however, their distribution appears to be more skewed towards the positive region of the plot.

These preliminary findings are corroborated by the analysis of the kernel density estimates of the relationship between democracy and growth and human capital and growth (Figure 2a). The peak of the distribution of human capital and growth lies, similarly to that of democracy and growth, in the positive area of the plot. However, the former shows a much higher density of positive effect sizes.

Finally, Figure 2b shows the kernel density estimates of the democracy and growth effect sizes based on the full sample (2047 observations) and the reduced sample (764 
Figure 2: K-density plots: comparison of different samples

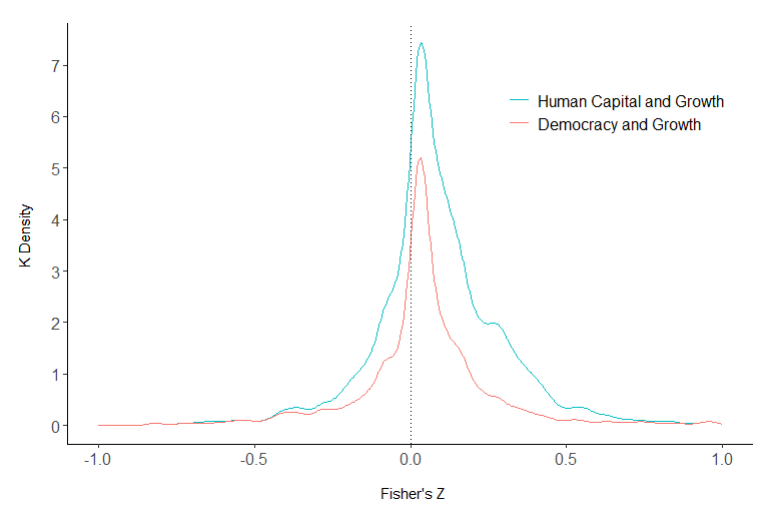

(a) Democracy, human capital and economic growth: kernel density comparison

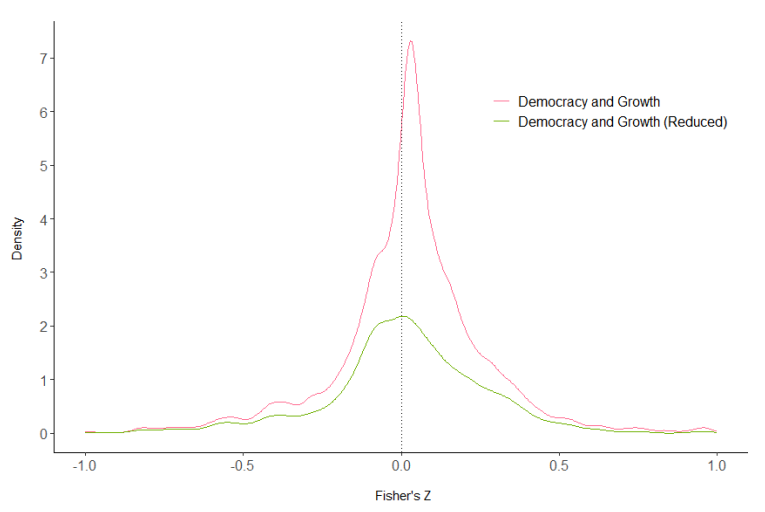

(b) Democracy and economic growth: kernel density comparison between the full sample and the reduced sample

estimates). Overall, the full sample shows a higher kurtosis and a peak just right of the line of the null effect. Conversely, the limited sample exhibits a lower kurtosis and a peak around the zero.

\subsection{Models}

Meta-analysis models can be divided between fixed effect and random effect(s) models. The main intuition behind fixed effect models is that the difference in the effect sizes is given by sampling variation. In other words, if the sample in each primary analysis converges towards infinity, each study will document the same effect size. Analytically, being $i=1, \ldots, n$ the effect sizes in the meta-analytic sample, the fixed effect model can be written as:

$$
y_{i}=\theta+\varepsilon_{i}, \quad \varepsilon_{i} \sim N\left(0, v_{i}^{2}\right)
$$

where $y_{i}$ is the effect size measure (the Fisher's Z score in our case), $\theta$ is the underlying (true) effect and $\varepsilon_{i}$ is the error term that is assumed to be normally distributed with mean 0 and variance $v_{i}^{2}$ - the (above mentioned) sampling variance. Such a model is then usually fitted by weighted least square with weights $w_{i}$ equal to 
$1 / v_{i}^{2}$

The choice between the fixed and random effect(s) models should not be based on the estimated heterogeneity (or the lack of thereof) of the sample as sometimes assumed, but rather on the inference required by the model itself (Hedges \& Vevea, 1998; Borenstein et al., 2010; Viechtbauer, 2010). When the interest lies in summarising the results of the $i$ effect sizes included in the sample (i.e. restricted inference) fixed effect models are to be preferred. This can be particularly useful in the analysis of sub-samples, such as our sample of human capital coefficients or the pre- and post-DU samples, where the sample of $i$ effect sizes is, by construction, not random with respect to study characteristics.

In contrast, random effect(s) models are recommended when the interest lies in drawing more general conclusions regarding an empirical relationship not restricted to the $i$ effect sizes included in the meta-analysis (i.e. unrestricted inference). However, unrestricted inference rests on the assumption that the effect sizes included in the meta-analysis are a random sample of all the effect sizes available or, in other words, that the selected studies are a random sample of the population of studies on the topic. $^{14}$

Analytically, with $i=1, \ldots, n$ being the effect sizes in the sample, the random effect model is given by:

$$
y_{i}=\theta+\eta_{i}+\varepsilon_{i}, \quad \eta_{i} \sim N\left(0, \tau^{2}\right), \quad \varepsilon_{i} \sim N\left(0, v_{i}^{2}\right)
$$

\footnotetext{
${ }^{14}$ The random sampling assumption plays a crucial role. If the sample of studies is not random with respect to study characteristics - e.g. a sub-sample based on the publication date, which is highly correlated, for example, with estimation techniques and time-span investigated - random effects model might be biased. In these cases, a better inference can be obtained by adopting fixed effect models.
} 
where $y_{i}$ is the effect size measure; $\theta$ is the underlying true effect; $\eta_{i}$ is the random effect introduced to model the variability among true effects and its variance $\left(\tau^{2}\right)$ indicates the amount of heterogeneity among them; and $\varepsilon_{i}$ is the variance component that is assumed to be normally distributed with mean 0 and variance $v_{i}^{2}$ (the sampling variance).

Random effect models are estimated using an iterative procedure. First, the heterogeneity $\tau^{2}$ is estimated through one of the (many) estimators proposed in the literature. ${ }^{15}$ Then $\theta$ is estimated through weighted least square with weights $w_{i}$ equal to $1 /\left(v_{i}^{2}+\tau^{2}\right)$

Equations 5 and 6 implicitly assume that the effect sizes are independent from each other. However, this assumption is unlikely to hold when studies contain multiple effect sizes, an issue sometimes known as "hierarchical dependence" (Stevens \& Taylor, 2009). Both the random and fixed effect model can accommodate for such a hierarchical data-structure via clustered standard errors, which however assumes within-cluster homogeneity. Hierarchical dependence can also be addressed through multilevel modelling, which allows to model without restrictive assumptions both the within-study and the between-studies heterogeneity and to measure them. ${ }^{16}$

Assuming $i=1, \ldots, n$ effect sizes and $j=1, \ldots, k$ studies, the multilevel (random

\footnotetext{
${ }^{15}$ Among the available estimators, our choice falls on the restricted maximum likelihood estimator, which "strikes a good balance between unbiasedness and efficiency" (Viechtbauer, 2005, p. 291).

${ }^{16}$ The $I^{2}$ statistic (Higgins et al., 2003) measures the between-studies consistency in a metaanalysis as:

$$
I^{2}=\left(\frac{Q-d f}{Q}\right) \times 100
$$

where $Q$ is the Cochran's $Q$ of the model (i.e. its $\chi^{2}$ statistics) and $d f$ are the degrees of freedom.
} 
effects) model can be written as:

$$
\begin{array}{r}
y_{i j}=\theta+\lambda_{j}+\eta_{i j}+\varepsilon_{i j} \\
\lambda_{j} \sim N\left(0, \sigma_{B}^{2}\right), \quad \eta_{i j} \sim N\left(0, \sigma_{W}^{2}\right), \quad \varepsilon_{i j} \sim N\left(0, v_{i j}^{2}\right)
\end{array}
$$

where $\theta$ is the average true outcome; $\lambda_{j}$ is the random effect that allows for heterogeneity between studies and $\sigma_{B}^{2}$ the corresponding between-studies variance; $\eta_{i j}$ is the random effect that allows for heterogeneity within studies and $\sigma_{W}^{2}$ is the between-observations within-study variance; and $\varepsilon_{i j}$ is the sampling error and $v_{i j}^{2}$ its variance.

\subsubsection{Meta-regression analysis}

Meta-regression analysis involves the regression of the observed effect sizes on one or multiple study characteristics. It can be used to address what Stanley \& Jarrell call the "problem of specification": the fact that different specifications, data-sets and statistical methods make it difficult to achieve consensus on a topic (Stanley \& Jarrell, 1989; Stanley, 2001).

All models shown in Section 3.3 can be easily adapted to include covariates to investigate the determinants behind the between- and within-study heterogeneity. As an example, it is possible to add $q$ predictors at the third level (the between-studies level) of the hierarchical (random effects) model and rewrite equation 7 as:

$$
\begin{array}{r}
y_{i j}=\theta_{0}+\theta_{1} X_{1 i j}+\ldots+\theta_{q} X_{q i j}+\lambda_{j}+\eta_{i j}+\varepsilon_{i j} \\
\lambda_{j} \sim N\left(0, \sigma_{R}^{2}\right), \quad \eta_{i j} \sim N\left(0, \sigma_{W}^{2}\right), \quad \varepsilon_{i j} \sim N\left(0, v_{i j}^{2}\right)
\end{array}
$$

where $X_{1 i j}, \ldots, X_{q i j}$ are study-level predictors and $\theta_{1}, \ldots, \theta_{q}$ their coefficients. The variance of $\lambda_{j}$ is now written as $\sigma_{R}^{2}$, since it indicates the residual between-studies variance (Konstantopoulos, 2011). 
Recently, Stanley \& Doucouliagos $(2015,2017)$ challenged the conventional meta (regression) models - fixed and random effect(s) - by proposing a third alternative: the unconditional weighted least square meta-regression analysis (henceforth UWLSMRA). Conventional meta-analytic models assume that the sampling variances are known. Conversely, the UWLS-MRA assumes that the sampling variances are known only up to a proportionality constant $\sigma_{e}^{2}$, which is "automatically estimated by the mean squared error, $M S_{E}$ " (Stanley \& Doucouliagos, 2017, p.22) ${ }^{17}$ Assuming again $q$ predictors to explain between-studies difference, the UWLS-MRA can be written as:

$$
y_{i}=\theta_{0}+\theta_{1} X_{1 i}+\ldots+\theta_{q} X_{q i}+\varepsilon_{i}, \quad \varepsilon_{i} \sim N\left(0, \sigma_{e}^{2} v_{i}^{2}\right)
$$

where $X_{1 i}, \ldots, X_{q i}$ are study-level predictors and $\theta_{1}, \ldots, \theta_{q}$ their coefficients. The model is then fitted via weighted least squares with weights $w_{i}$ equal to $1 /\left(\sigma_{e}^{2} v_{i}^{2}\right)$. Therefore, while in random effect(s) meta-analysis unrestricted inferences is obtained through an additive factor (i.e. $\tau^{2}$ ), the UWLS-MRA addresses excess heterogeneity via a multiplicative factor. There is little or no rationale for such a multiplicative factor. ${ }^{18}$ However, the simulations reported by Stanley \& Doucouliagos $(2015,2017)$ show that there is little difference between random effects models and the UWLSMRA, which appears to be even superior when there is a sizeable publication bias. We will therefore present, for the meta-regression analysis, also the results of Equation 9. As with the random and fixed effect model, to account for the hierarchical dependence in our data, we will cluster the standard errors at study level. ${ }^{19}$

\footnotetext{
${ }^{17}$ Standard meta-analytic models instead suppose that $\sigma_{e}^{2}=1$.

18 "[T] he idea that the variance of the estimated effect within each study should be multiplied by some constant has little intuitive appeal, [...] we do not recommend them in practice" (Thompson \& Sharp, 1999, p. 2705).

${ }^{19}$ It is not clear whether Equation 9 can account for the effect sizes' hierarchical dependence in a
} 


\section{Results}

\subsection{Meta-Analysis}

The findings of our meta-analysis are summarised in Table 2. Alternative metaanalytic estimators are presented across columns while alternative samples are reported across rows. Standard errors, in parentheses, are shown below coefficients.

The first row provides the estimated effect of democracy on economic growth in the full sample: it is positive and strongly significant $(\mathrm{p}<0.01)$ in all meta-analytic models. Both total and between-studies heterogeneity $\left(I^{2}\right)$ display large values, thus supporting the appropriateness of a MRA (see Section 4.2). ${ }^{20}$

Table 2: Meta-analysis, full sample

\begin{tabular}{|c|c|c|c|c|c|c|}
\hline & $\begin{array}{c}\text { RE ML } \\
\text { (s.e.) }\end{array}$ & $\begin{array}{c}\text { FE } \\
\text { (clustered s.e.) }\end{array}$ & $\begin{array}{c}\mathrm{RE} \\
\text { (clustered s.e.) }\end{array}$ & $\begin{array}{c}\text { Total Îे } \\
{[\text { Between Îे] }}\end{array}$ & ICC & $\begin{array}{c}\text { Studies } \\
\text { [Effect sizes] }\end{array}$ \\
\hline \multirow[t]{2}{*}{ Democracy } & $0.0440^{* *}$ & $0.0338^{* * *}$ & $0.0464^{* *}$ & $97.96 \%$ & 0.892 & 188 \\
\hline & $(0.0138)$ & $(0.0041)$ & $(0.0152)$ & {$[87.34 \%]$} & & [2047] \\
\hline \multirow{2}{*}{ Human capital } & $0.1348^{* * *}$ & $0.0750^{* * *}$ & $0.1183^{* * *}$ & $90.62 \%$ & 0.798 & 111 \\
\hline & $(0.0156)$ & $(0.0134)$ & $(0.0126)$ & {$[72.33 \%]$} & & [875] \\
\hline Democracy & 0.0151 & 0.0203 & 0.0127 & $92.35 \%$ & 0.718 & 111 \\
\hline (Reduced sample) & $(0.0166)$ & $(0.0168)$ & $(0.0169)$ & {$[66.31 \%]$} & & [764] \\
\hline Democracy & $0.0430^{* *}$ & $0.0363^{* * *}$ & $0.0494^{* * *}$ & $96.93 \%$ & 0.821 & 180 \\
\hline (Main specifications) & $(0.0141)$ & $(0.0055)$ & $(0.0131)$ & [79.6\%] & & [1227] \\
\hline
\end{tabular}

Notes: Standard errors in round parentheses, as indicated in columns' headers.

Significance levels $* * * 0.001 * * 0.01 * 0.05$

Results are substantially unaffected when the sample includes only main specifications, as shown in the fourth row of Table 2. The growth impact of democracy remains positive and significant $(\mathrm{p}<0.01)$. Overall, our findings show that there is a

multilevel setting. Stanley \& Doucouliagos (2017) suggest that meta-regressions can adopt multilevel methods to account for the fact that "estimates within the same study are likely to be dependent on each other". However, applying the unconditional weighted least square method to a multilevel model implies adopting additive and multiplicative variance components simultaneously. Such a possibility does not have any theoretical rationale and, to the best of our knowledge, has not yet been either discussed or tested.

${ }^{20}$ In Appendix B we present the results of Table 2 after excluding non-linear specifications (Table B.1). Results hold. 
direct effect of democracy on economic growth, supporting the claim that "democracy does cause growth" (Acemoglu et al., 2019).

The second row reports, as a comparison, the estimated growth effect of human capital. There is indeed a shared consensus (e.g. Barro, 2001; Cohen \& Soto, 2007; Ciccone \& Papaioannou, 2009) that human capital is positively linked to economic growth. Our analysis shows that human capital has a sizeable and statistically significant impact on economic growth and its magnitude is two to three times larger than the impact of democracy on growth once the effect of human capital is accounted for. However, it is important to acknowledge that these results should not be taken as a meta-analytical estimate of the direct effect of human capital on growth. Our sample contains only estimates of human capital at constant levels of democracy and does not aim at representing of the whole population of studies on human capital and growth. In a meta-analysis on the topic based on a rather different set of papers, Benos \& Zotou show that there appears to be a substantial publication bias toward positive growth effects of human capital and "the growth impact of education after taking into account publication bias hinges upon the specific features of each study" (Benos \& Zotou, 2014, p. 687).

In the third row, we consider only those models in which Fisher's Z scores of the partial correlation between democracy and growth are at constant levels of human capital (Reduced sample). All three estimation techniques show that the effect of democracy on economic growth is now not significant. Human capital and democracy are most likely highly correlated. While part of the literature (Tavares \& Wacziarg, 2001) claims that the effect of democracy is mostly channelled through human capital (a claim confirmed by Doucouliagos \& Ulubaşoğlu, 2008), from our analysis we cannot exclude that the effect goes in the opposite direction: democracy might be a channel for the effect of education on growth. 
Table 3: Meta-Analysis: A comparison before and after Doucouliagos \& Ulubaşoğlu (2008)

\begin{tabular}{lccc}
\hline & Pre-DU & & Post-DU \\
\cline { 2 - 3 } & $\begin{array}{c}\text { FE } \\
\text { (clustered s.e.) }\end{array}$ & & $\begin{array}{c}\text { FE } \\
\text { (clustered s.e.) }\end{array}$ \\
\hline \multirow{2}{*}{ Democracy } & 0.0287 & & $0.0343 * * *$ \\
& $(0.0202)$ & $(0.0042)$ \\
\hline Studies & 94 & 94 \\
Eff. Sizes & 741 & 1306 \\
\hline
\end{tabular}

Notes: Fixed effect models (equation 5). Clustered standard errors in parentheses. The pre- $D U$ sample contains only estimates collected from studies published before December 2005 - the date in which the search for studies by Doucouliagos \& Ulubaşoğlu (2008) ended. The post-DU sample contains instead only estimates collected from studies published after December 2005.

Significance levels $* * * 0.001 * * 0.01 * 0.05$

Finally, in Table 3 we show the differences between the sub-sample of studies that have been published before (pre-DU) and after (post-DU) the meta-analysis by Doucouliagos \& Ulubaşoğlu (2008). ${ }^{21}$

Results show that studies published before December 2005 failed to find a direct growth effect of democracy. Also (Doucouliagos \& Ulubaşoğlu, 2008) does not find any direct effect of democracy on economic growth. However, the picture changes after 2005: newer studies show that democracy has a positive effect on growth.

\subsection{Meta-Regression Analysis}

Table 4 provides a description of all the potential sources of heterogeneity investigated in the MRA. ${ }^{22}$ We account for the high values of $I^{2}$ found in Table 2 by considering: the different data structure underlying each model specification; the

\footnotetext{
${ }^{21}$ These sub-samples are obtained through a non-random pattern in the selection of studies. Therefore, unrestricted inference (i.e. random effect models) can not be applied, since its underlying assumptions are violated (see Section 3).

${ }^{22}$ It is worth noticing that the total heterogeneity is substantially large and in line with the levels found in many other meta-analyses (see Ioannidis et al., 2017).
} 
estimation strategies and research designs adopted by the scholars in the field; the extent of non-linearities in the modelling of democracy; the different proxies chosen for both democracy and economic growth; the (several) control variables adopted; the geographical and time composition of the sample(s) of countries.

Table 4: Description of meta-regression variables

\begin{tabular}{|c|c|}
\hline Variable name & Variable description \\
\hline \multicolumn{2}{|l|}{ Data structure } \\
\hline Panel & $\begin{array}{l}=1 \text { if the model uses panel data (yearly observations). Omitted reference } \\
\text { category }\end{array}$ \\
\hline Cross-section & $=1$ if the model uses cross-sectional data \\
\hline Time-series & $=1$ if the model adopts time-series analysis techniques \\
\hline Panel (avg) & $\begin{array}{l}=1 \text { if the model uses panel data averaging observations within regular sub- } \\
\text { periods }\end{array}$ \\
\hline \multicolumn{2}{|c|}{ Estimation techniques } \\
\hline OLS & $\begin{array}{l}=1 \text { if coefficients are estimated through Ordinary Least Square. Omitted } \\
\text { reference category }\end{array}$ \\
\hline $\mathrm{GE}$ & $=1$ if the model controls for unaccounted time-invariant variables \\
\hline $\mathrm{DPD}$ & $=1$ if the model is estimated through dynamic panel data (DPD) model \\
\hline \multicolumn{2}{|c|}{ Other techniques $=1$ if the model is estimated through estimation techniques not listed above } \\
\hline \multicolumn{2}{|c|}{ Non-linear specifications } \\
\hline Non-linearity & c term of democracy \\
\hline Interaction & $=1$ if democracy is also included in an interaction term \\
\hline Multiple & $=1$ if the specification includes more than one proxy of democracy \\
\hline \multicolumn{2}{|c|}{ Dependent variable } \\
\hline Level & $\begin{array}{l}=1 \text { if the dependent variable is expressed in levels of GDP/GNP and no } \\
\text { lagged value of the dependent variable is included in the right-hand side }\end{array}$ \\
\hline \multicolumn{2}{|l|}{$\overline{\text { Democracy }}$} \\
\hline $\mathrm{FH}$ & $=1$ if Freedom House is the proxy of democracy. Omitted reference category \\
\hline Polity & $=1$ if Polity Index is the proxy of democracy \\
\hline Dichotomous & $=1$ if a dichotomous variable is the proxy of democracy \\
\hline Other proxies & $=1$ if none of the above is a proxy of democracy \\
\hline \multicolumn{2}{|l|}{ Control variables } \\
\hline Convergence & $=1$ if the specification includes a \\
\hline Investment & $=1$ if the specification includes a proxy for investment a/o physical capital \\
\hline Govern size & $=1$ if the specification includes a proxy for government size \\
\hline Human capital & $=1$ if the specification includes a proxy for human capital \\
\hline Corruption & $=1$ if the specification includes a proxy for corruption \\
\hline Ethnicity & $=1$ if the specification includes a proxy for ethnicity \\
\hline Religion & $=1$ if the specification includes a proxy for religion \\
\hline Econ freedom & $=1$ if the specification includes a proxy for economic freedom \\
\hline Rule of law & $=1$ if the specification includes a proxy for rule of law a/o property rights \\
\hline State capacity & $=1$ if the specification includes a proxy for state capacity \\
\hline
\end{tabular}


Table 4 continued from previous page

\begin{tabular}{|c|c|}
\hline Variable name & Variable description \\
\hline $\begin{array}{l}\text { Openness } \\
\text { Population }\end{array}$ & $\begin{array}{l}=1 \text { if the specification includes a proxy for financial and economic openness } \\
=1 \text { if the specification includes a proxy for population growth and/or level }\end{array}$ \\
\hline \multicolumn{2}{|l|}{ World regions } \\
\hline Africa & $=1$ if the sample includes at least two countries from Sub-Saharan Africa \\
\hline East Asia & $=1$ if the sample includes at least two countries from East Asia \\
\hline East Europe & $=1$ if the sample includes at least two countries from East Europe \\
\hline Latin America & $=1$ if the sample includes at least two countries from Latin America \\
\hline Middle East & $\begin{array}{l}=1 \text { if the sample includes at least two countries from Middle East and } \\
\text { North Africa }\end{array}$ \\
\hline South Asia & $=1$ if the sample includes at least two countries from South Asia \\
\hline High-income & $=1$ if the sample includes at least two countries from high-income countries \\
\hline \multicolumn{2}{|c|}{ Region dummies $=1$ if the study includes regional dummies } \\
\hline \multicolumn{2}{|l|}{ Time periods } \\
\hline $1940 \mathrm{~s}$ & $=1$ if at least one observations is dated $1940-1949$ \\
\hline $1950 \mathrm{~s}$ & $=1$ if at least one observations is dated $1950-1959$ \\
\hline $1960 \mathrm{~s}$ & $=1$ if at least one observations is dated $1960-1969$ \\
\hline 1970s & $=1$ if at least one observations is dated $1970-1979$ \\
\hline $1980 \mathrm{~s}$ & $=1$ if at least one observations is dated $1980-1989$ \\
\hline $1990 \mathrm{~s}$ & $=1$ if at least one observations is dated $1990-1999$ \\
\hline $2000 \mathrm{~s}$ & $=1$ if at least one observations is dated $2000-2009$ \\
\hline $2010 \mathrm{~s}$ & $=1$ if at least one observations is dated $2010-2017$ \\
\hline
\end{tabular}

Table 5 presents the main results of our MRA. ${ }^{23}$ It compares the estimated effect of each covariate on the relationship between democracy and growth according to the four alternative estimators detailed in Section 3.3. During the discussion of our findings, we will mainly focus on the results obtained in our preferred model, the multilevel (random effects) model (RE ML). Importantly, the other models considered show no case of conflicting results.

\footnotetext{
${ }^{23}$ In Appendix $\mathrm{B}$ we test the robustness of our MRA by: testing multicollinearity issues by estimating each set of covariates separately (Table B.3); adopting raw partial correlations as effect sizes (Table B.4); including only effect sizes collected from main specifications (Table B.5); including a set of additional control variables accounting for publication-quality and other publication-related characteristics (tables B.6 and B.7). Results are unchanged.
} 
Table 5: Meta-regression, full sample, alternative estimators

\begin{tabular}{|c|c|c|c|c|c|}
\hline & $\begin{array}{c}(1) \\
\text { RE ML } \\
\text { (s.e.) }\end{array}$ & $\begin{array}{c}(2) \\
\text { FE } \\
\text { (clus. s.e.) }\end{array}$ & $\begin{array}{c}(3) \\
\text { UWLS } \\
\text { (clus. s.e.) }\end{array}$ & $\begin{array}{c}(4) \\
\mathbf{R E} \\
\text { (clus. s.e.) }\end{array}$ & $\begin{array}{c}\text { Studies } \\
\text { [Eff. sizes] }\end{array}$ \\
\hline \multicolumn{6}{|l|}{ Data structure } \\
\hline Cross-section & $\begin{array}{c}0.0413 \\
(0.0217)\end{array}$ & $\begin{array}{c}0.0448 \\
(0.0287)\end{array}$ & $\begin{array}{c}0.0448 \\
(0.0256)\end{array}$ & $\begin{array}{c}0.0470 \\
(0.0314)\end{array}$ & $\begin{array}{r}81 \\
{[603]}\end{array}$ \\
\hline Time-series & $\begin{array}{c}0.1168 \\
(0.0697)\end{array}$ & $\begin{array}{c}0.2961 \\
(0.3073)\end{array}$ & $\begin{array}{c}0.2961 \\
(0.2743)\end{array}$ & $\begin{array}{r}0.4220 * \\
(0.1887)\end{array}$ & $\begin{array}{r}11 \\
{[100]}\end{array}$ \\
\hline Panel (avg) & $\begin{array}{l}0.0299 * * \\
(0.0106)\end{array}$ & $\begin{array}{c}0.0166 \\
(0.0155)\end{array}$ & $\begin{array}{c}0.0166 \\
(0.0138)\end{array}$ & $\begin{array}{c}0.0456 * \\
(0.0227)\end{array}$ & $\begin{array}{r}63 \\
{[663]}\end{array}$ \\
\hline \multicolumn{6}{|c|}{ Estimation techniques } \\
\hline $\mathrm{FE}$ & $\begin{array}{c}-0.0171 \\
(0.0137)\end{array}$ & $\begin{array}{c}-0.0125 \\
(0.0166)\end{array}$ & $\begin{array}{c}-0.0125 \\
(0.0148)\end{array}$ & $\begin{array}{c}-0.0488 \\
(0.031)\end{array}$ & $\begin{array}{r}67 \\
{[777]}\end{array}$ \\
\hline DPD & $\begin{array}{c}0.0038 \\
(0.0175)\end{array}$ & $\begin{array}{c}-0.0331 \\
(0.0229)\end{array}$ & $\begin{array}{c}-0.0331 \\
(0.0205)\end{array}$ & $\begin{array}{c}-0.1026 * \\
(0.0435)\end{array}$ & $\begin{array}{r}20 \\
{[233]}\end{array}$ \\
\hline Other techniques & $\begin{array}{c}-0.0027 \\
(0.0143)\end{array}$ & $\begin{array}{c}0.0114 \\
(0.0203)\end{array}$ & $\begin{array}{c}0.0114 \\
(0.0181)\end{array}$ & $\begin{array}{c}-0.0195 \\
(0.031)\end{array}$ & $\begin{array}{r}54 \\
{[370]}\end{array}$ \\
\hline \multicolumn{6}{|c|}{ Non-linear specifications } \\
\hline Non-linearity & $\begin{array}{c}-0.0864 * * * \\
(0.0163)\end{array}$ & $\begin{array}{c}-0.0275 \\
(0.0214)\end{array}$ & $\begin{array}{c}-0.0275 \\
(0.0191)\end{array}$ & $\begin{array}{c}-0.0959 * * \\
(0.0362)\end{array}$ & $\begin{array}{r}25 \\
{[248]}\end{array}$ \\
\hline Interaction & $\begin{array}{c}-0.0120 \\
(0.0090)\end{array}$ & $\begin{array}{c}-0.0023 \\
(0.0089)\end{array}$ & $\begin{array}{c}-0.0023 \\
(0.0079)\end{array}$ & $\begin{array}{c}-0.0024 \\
(0.0218)\end{array}$ & $\begin{array}{r}40 \\
{[403]}\end{array}$ \\
\hline Multiple & $\begin{array}{c}-0.1061 * * * \\
(0.0313)\end{array}$ & $\begin{array}{c}-0.0302 \\
(0.0226)\end{array}$ & $\begin{array}{c}-0.0302 \\
(0.0202)\end{array}$ & $\begin{array}{c}-0.0371 \\
(0.0317)\end{array}$ & $\begin{array}{r}10 \\
{[68]}\end{array}$ \\
\hline \multicolumn{6}{|l|}{ Dependent variable } \\
\hline Level & $\begin{array}{c}0.0384 \\
(0.0255)\end{array}$ & $\begin{array}{r}-0.0297 \\
(0.0236)\end{array}$ & $\begin{array}{c}-0.0297 \\
(0.0211)\end{array}$ & $\begin{array}{r}-0.0275 \\
(0.0797)\end{array}$ & $\begin{array}{r}13 \\
{[54]}\end{array}$ \\
\hline \multicolumn{6}{|l|}{ Democracy } \\
\hline Polity & $\begin{array}{c}0.0010 \\
(0.0086)\end{array}$ & $\begin{array}{c}-0.0103 \\
(0.0127)\end{array}$ & $\begin{array}{c}-0.0103 \\
(0.0113)\end{array}$ & $\begin{array}{c}-0.0129 \\
(0.0183)\end{array}$ & $\begin{array}{r}80 \\
{[771]}\end{array}$ \\
\hline Dichotomous & $\begin{array}{c}-0.0156 \\
(0.0109)\end{array}$ & $\begin{array}{c}0.0023 \\
(0.0112)\end{array}$ & $\begin{array}{c}0.0023 \\
(0.0100)\end{array}$ & $\begin{array}{c}0.0232 \\
(0.0221)\end{array}$ & $\begin{array}{r}39 \\
{[361]}\end{array}$ \\
\hline Other proxies & $\begin{array}{c}0.0003 \\
(0.0084)\end{array}$ & $\begin{array}{c}-0.0137 \\
(0.0096)\end{array}$ & $\begin{array}{c}-0.0137 \\
(0.0085)\end{array}$ & $\begin{array}{c}0.0035 \\
(0.0237)\end{array}$ & $\begin{array}{r}28 \\
{[323]}\end{array}$ \\
\hline \multicolumn{6}{|l|}{ Control variables } \\
\hline Convergence & $\begin{array}{c}0.0310 * \\
(0.0123)\end{array}$ & $\begin{array}{c}0.0043 \\
(0.0142)\end{array}$ & $\begin{array}{c}0.0043 \\
(0.0127)\end{array}$ & $\begin{array}{c}0.0195 \\
(0.0302)\end{array}$ & $\begin{array}{r}152 \\
{[1748]}\end{array}$ \\
\hline Investment & $\begin{array}{c}0.0064 \\
(0.0109)\end{array}$ & $\begin{array}{c}-0.024 \\
(0.0136)\end{array}$ & $\begin{array}{c}-0.0240 * \\
(0.0122)\end{array}$ & $\begin{array}{c}-0.0576 * * \\
(0.0206)\end{array}$ & $\begin{array}{r}120 \\
{[920]}\end{array}$ \\
\hline Govern size & $\begin{array}{c}0.0114 \\
(0.0104)\end{array}$ & $\begin{array}{c}0.0024 \\
(0.0113)\end{array}$ & $\begin{array}{c}0.0024 \\
(0.0101)\end{array}$ & $\begin{array}{c}0.0231 \\
(0.0216)\end{array}$ & $\begin{array}{r}69 \\
{[550]}\end{array}$ \\
\hline Human capital & $\begin{array}{c}-0.0083 \\
(0.0100)\end{array}$ & $\begin{array}{c}-0.0073 \\
(0.0101)\end{array}$ & $\begin{array}{c}-0.0073 \\
(0.0091)\end{array}$ & $\begin{array}{c}-0.0193 \\
(0.0196)\end{array}$ & $\begin{array}{r}120 \\
{[991]}\end{array}$ \\
\hline Corruption & $\begin{array}{c}0.0164 \\
(0.0344)\end{array}$ & $\begin{array}{c}0.0135 \\
(0.0207)\end{array}$ & $\begin{array}{c}0.0135 \\
(0.0185)\end{array}$ & $\begin{array}{c}0.0273 \\
(0.0352)\end{array}$ & $\begin{array}{r}20 \\
{[158]}\end{array}$ \\
\hline Ethnicity & 0.0006 & -0.0248 & $-0.0248 *$ & $-0.0562 *$ & 18 \\
\hline
\end{tabular}


Table 5 - continued from previous page

\begin{tabular}{|c|c|c|c|c|c|}
\hline & $\begin{array}{c}(1) \\
\text { RE ML } \\
\text { (s.e.) }\end{array}$ & $\begin{array}{c}(2) \\
\text { FE } \\
\text { (clus. s.e.) }\end{array}$ & $\begin{array}{c}(3) \\
\text { UWLS } \\
\text { (clus. s.e.) }\end{array}$ & $\begin{array}{c}(4) \\
\mathbf{R E} \\
\text { (clus. s.e.) }\end{array}$ & $\begin{array}{c}\text { Studies } \\
{[\text { Eff. sizes] }}\end{array}$ \\
\hline & $(0.0163)$ & $(0.013)$ & $(0.0116)$ & $(0.0257)$ & {$[122]$} \\
\hline Religion & -0.0152 & 0.015 & 0.0150 & 0.0783 & $\begin{array}{r}7 \\
{[357}\end{array}$ \\
\hline Econ freedom & $\begin{array}{c}-0.0180 \\
(0.0172)\end{array}$ & $\begin{array}{c}-0.028 \\
(0.0146)\end{array}$ & $\begin{array}{c}-0.0280 * \\
(0.013)\end{array}$ & $\begin{array}{c}-0.0274 \\
(0.034)\end{array}$ & $\begin{array}{r}26 \\
{[115]}\end{array}$ \\
\hline Rule of law & $\begin{array}{c}-0.0066 \\
(0.021)\end{array}$ & $\begin{array}{l}-0.022 \\
(0.0255)\end{array}$ & $\begin{array}{l}-0.022 \\
(0.0228)\end{array}$ & $\begin{array}{c}0.0113 \\
(0.0299)\end{array}$ & $\begin{array}{r}26 \\
{[239]}\end{array}$ \\
\hline State capacity & $\begin{array}{c}0.0558 * \\
(0.0220)\end{array}$ & $\begin{array}{l}0.0424 * * \\
(0.0146)\end{array}$ & $\begin{array}{l}0.0424 * * \\
(0.013)\end{array}$ & $\begin{array}{c}0.0513 \\
(0.0459)\end{array}$ & $\begin{array}{r}3 \\
3 \\
{[31]}\end{array}$ \\
\hline Openness & $\begin{array}{r}-0.0079 \\
(0.0095)\end{array}$ & $\begin{array}{c}0.0004 \\
(0.0124)\end{array}$ & $\begin{array}{c}0.0004 \\
(0.0111)\end{array}$ & $\begin{array}{c}0.0273 \\
(0.0213)\end{array}$ & $\begin{array}{r}86 \\
{[902]}\end{array}$ \\
\hline Population & $\begin{array}{c}-0.0239 * \\
(0.0104)\end{array}$ & $\begin{array}{r}-0.0043 \\
(0.0115)\end{array}$ & $\begin{array}{c}-0.0043 \\
(0.0102)\end{array}$ & $\begin{array}{c}-0.0098 \\
(0.0204)\end{array}$ & $\begin{array}{r}79 \\
{[849]}\end{array}$ \\
\hline \multicolumn{6}{|l|}{ World regions } \\
\hline Africa & $\begin{array}{l}0.1757 * * * \\
(0.0148)\end{array}$ & $\begin{array}{c}0.0755 \\
(0.0414)\end{array}$ & $\begin{array}{l}0.0755 * \\
(0.037)\end{array}$ & $\begin{array}{c}0.1742 * \\
(0.0814)\end{array}$ & $\begin{array}{r}161 \\
{[1773]}\end{array}$ \\
\hline East Asia & $\begin{array}{c}-0.0289 \\
(0.0431)\end{array}$ & $\begin{array}{c}0.0283 \\
(0.0787)\end{array}$ & $\begin{array}{c}0.0283 \\
(0.0702)\end{array}$ & $\begin{array}{c}0.0783 \\
(0.1033)\end{array}$ & $\begin{array}{r}150 \\
{[1657]}\end{array}$ \\
\hline East Europe & $\begin{array}{c}0.0148 \\
(0.0187)\end{array}$ & $\begin{array}{r}-0.0096 \\
(0.0189)\end{array}$ & $\begin{array}{c}-0.0096 \\
(0.0169)\end{array}$ & $\begin{array}{c}0.0267 \\
(0.0333)\end{array}$ & $\begin{array}{r}125 \\
{[1388]}\end{array}$ \\
\hline Latin America & $\begin{array}{r}-0.0120 \\
(0.0193)\end{array}$ & $\begin{array}{c}0.0093 \\
(0.0249)\end{array}$ & $\begin{array}{c}0.0093 \\
(0.0222)\end{array}$ & $\begin{array}{c}0.0467 \\
(0.0492)\end{array}$ & $\begin{array}{r}152 \\
{[1682]}\end{array}$ \\
\hline Middle East & $\begin{array}{c}0.0310 \\
(0.0182)\end{array}$ & $\begin{array}{c}0.0189 \\
(0.0214)\end{array}$ & $\begin{array}{c}0.0189 \\
(0.0191)\end{array}$ & $\begin{array}{c}0.0296 \\
(0.0499)\end{array}$ & $\begin{array}{r}155 \\
{[1561]}\end{array}$ \\
\hline South Asia & $\begin{array}{c}-0.1117 * * \\
(0.0412)\end{array}$ & $\begin{array}{c}-0.0699 \\
(0.0823)\end{array}$ & $\begin{array}{c}-0.0699 \\
(0.0735)\end{array}$ & $\begin{array}{c}-0.2547 * * \\
(0.0942)\end{array}$ & $\begin{array}{r}146 \\
{[1642]}\end{array}$ \\
\hline High-income & $\begin{array}{r}0.0241 * \\
(0.0094)\end{array}$ & $\begin{array}{c}-0.0082 \\
(0.0104)\end{array}$ & $\begin{array}{c}-0.0082 \\
(0.0093)\end{array}$ & $\begin{array}{l}0.003 \\
(0.0217)\end{array}$ & $\begin{array}{r}129 \\
{[1299]}\end{array}$ \\
\hline Region dummies & $\begin{array}{c}-0.0062 \\
(0.0102)\end{array}$ & $\begin{array}{c}0.0076 \\
(0.0066)\end{array}$ & $\begin{array}{c}0.0076 \\
(0.0059)\end{array}$ & $\begin{array}{l}0.0177 \\
(0.02)\end{array}$ & $\begin{array}{r}33 \\
{[211]}\end{array}$ \\
\hline Time periods & & & & & \\
\hline $1940 \mathrm{~s}$ & $\begin{array}{c}0.0382 \\
(0.033)\end{array}$ & $\begin{array}{r}-0.0581 * \\
(0.0284)\end{array}$ & $\begin{array}{c}-0.0581 * \\
(0.0254)\end{array}$ & $\begin{array}{c}-0.225 \\
(0.1598)\end{array}$ & $\begin{array}{r}3 \\
{[34]}\end{array}$ \\
\hline $1950 \mathrm{~s}$ & $\begin{array}{r}-0.0050 \\
(0.0206)\end{array}$ & $\begin{array}{r}0.0193 * \\
(0.0096)\end{array}$ & $\begin{array}{c}0.0193 * \\
(0.0085)\end{array}$ & $\begin{array}{c}0.0525 \\
(0.0284)\end{array}$ & $\begin{array}{r}16 \\
{[106]}\end{array}$ \\
\hline $1960 \mathrm{~s}$ & $\begin{array}{l}-0.0605 * * * \\
(0.0148)\end{array}$ & $\begin{array}{c}-0.0206 \\
(0.0142)\end{array}$ & $\begin{array}{c}-0.0206 \\
(0.0127)\end{array}$ & $\begin{array}{c}-0.0398 \\
(0.0251)\end{array}$ & $\begin{array}{r}95 \\
{[990]}\end{array}$ \\
\hline $1970 \mathrm{~s}$ & $\begin{array}{c}-0.0424 * * \\
(0.0144)\end{array}$ & $\begin{array}{c}-0.0356 \\
(0.0206)\end{array}$ & $\begin{array}{c}-0.0356 \\
(0.0184)\end{array}$ & $\begin{array}{c}-0.0193 \\
(0.0294)\end{array}$ & $\begin{array}{r}140 \\
{[1525]}\end{array}$ \\
\hline $1980 \mathrm{~s}$ & $\begin{array}{l}0.0863 * * * \\
(0.0164)\end{array}$ & $\begin{array}{r}0.0689 * \\
(0.0276)\end{array}$ & $\begin{array}{l}0.0689 * * \\
(0.0247)\end{array}$ & $\begin{array}{c}0.0655 \\
(0.0367)\end{array}$ & $\begin{array}{r}157 \\
{[1763]}\end{array}$ \\
\hline $1990 \mathrm{~s}$ & $\begin{array}{c}0.0136 \\
(0.0187)\end{array}$ & $\begin{array}{c}0.0177 \\
(0.0216)\end{array}$ & $\begin{array}{c}0.0177 \\
(0.0193)\end{array}$ & $\begin{array}{c}0.0185 \\
(0.0266)\end{array}$ & $\begin{array}{r}108 \\
{[1458]}\end{array}$ \\
\hline $2000 \mathrm{~s}$ & $-0.0409 *$ & -0.0058 & -0.0058 & -0.0273 & 70 \\
\hline
\end{tabular}


Table 5 - continued from previous page

\begin{tabular}{|c|c|c|c|c|c|}
\hline & $\begin{array}{c}(1) \\
\text { RE ML } \\
\text { (s.e.) }\end{array}$ & $\begin{array}{c}(2) \\
\text { FE } \\
\text { (clus. s.e.) }\end{array}$ & $\begin{array}{c}(3) \\
\text { UWLS } \\
\text { (clus. s.e.) }\end{array}$ & $\begin{array}{c}(4) \\
\text { RE } \\
\text { (clus. s.e.) }\end{array}$ & $\begin{array}{c}\text { Studies } \\
\text { [Eff. sizes] }\end{array}$ \\
\hline & $(0.0185)$ & $(0.0158)$ & $(0.0141)$ & $(0.0274)$ & [1019] \\
\hline $2010 \mathrm{~s}$ & $\begin{array}{c}0.0170 \\
(0.0383)\end{array}$ & $\begin{array}{r}0.0408 * \\
(0.0171)\end{array}$ & $\begin{array}{l}0.0408 * * \\
(0.0152)\end{array}$ & $\begin{array}{c}0.1035 * * \\
(0.0395)\end{array}$ & $\begin{array}{r}22 \\
{[281]}\end{array}$ \\
\hline Constant term & $\begin{array}{r}-0.0674 \\
(0.0366)\end{array}$ & $\begin{array}{r}-0.0343 \\
(0.0507)\end{array}$ & $\begin{array}{r}-0.0343 \\
(0.0453)\end{array}$ & $\begin{array}{r}-0.0753 \\
(0.0693)\end{array}$ & $\begin{array}{r}188 \\
{[2047]}\end{array}$ \\
\hline
\end{tabular}

Notes: Standard errors in round parentheses as indicated in column headers. The sample is composed by 2047 observations (188 studies).

Significance levels $* * * 0.001 * * 0.01 * 0.05$

Data structure. The first block of three rows in Table 5 illustrates that the way data are structured impacts the estimated growth effect of democracy. Averaging observations over sub-periods (usually 5 or 10 years) in panel data positively affects the outcome of the partial correlation. Averaging observations attenuates the effect of economic cycles, hence capturing longer-term trends. The coefficients of alternative data structures are not statistically different from 0 when compared to the reference (omitted) category, which is Panel - panel data with yearly observations.

Estimation techniques. Different estimation techniques do not systematically affect the partial correlation between democracy and growth when compared with the omitted reference category (OLS). Rather than the estimator per se, the core issue seems to be related to the modelling of endogeneity, as shown by the robustness checks reported in Table B.8. Here the set of dummies related to the estimation techniques are replaced with a single dummy identifying whether a specification explicitly models endogeneity: the coefficient of Endogeneity is positive and significant. ${ }^{24}$ Overall, our finding seems to justify the large attention that the literature paid to the endogeneity of the relationship between democratic institutions and growth (e.g. Lipset, 1959;

\footnotetext{
${ }^{24}$ In the case of IV models, the recent literature has shown that IV estimates are often much higher than OLS estimates (see Jiang, 2017). We thank an anonymous reviewer for this suggestion.
} 
Barro, 1999).

Non-linear specifications. The inclusion of a quadratic term of democracy in the model specification is associated with a downward bias of the effect size. Unfortunately, we can not provide further interpretation of these results as studies do not report the covariance between the linear and quadratic forms of the proxy of democracy used. Similarly, including multiple proxies of democracy exerts a significant negative effect on the estimated effect size. ${ }^{25}$ This result may simply suggest a mechanical relation occurring in the estimation procedures, likely driven by the introduction of collinearity in the model.

Dependent variable. Some scholars adopt levels rather than growth rates to investigate the effect of democracy on economic activity. When there is a lagged value of the level of economic growth on the right-hand side of the equation it is easy to show that models using levels produce "identical coefficient estimates and standard errors for the other explanatory variables as a specification with growth as the dependent variable and lagged income included as an explanatory variable" (Gunby et al., 2017, p. 253). However, when the dependent variable is expressed in levels of GDP/GNP and there is no lagged value of the dependent variable in the right-hand side, the model is informing about production levels rather than economic growth. Therefore, we control through the dummy variable Level when effect sizes are collected from specifications of the latter type. Table 5 shows that this variable is never statistically significant. Further, our results are robust to the exclusion of these effect sizes (see Table B.11).

\footnotetext{
${ }^{25}$ This features is mostly adopted by earlier studies including in the same model both the Political Rights Freedom and the Civil Liberties Freedom measures provided by Freedom House.
} 
Democracy. The definition and measurement of democracy is a key issue in the literature. Therefore, we carefully collected all the alternative indicators adopted in our sample of studies. Since the distribution of alternative indicators is uneven, with some of them that are very popular in the literature and other that are less used, we distinctly identified only the most frequently used proxies, consistently aggregating the remaining. According to our MRA, the choice among the most common proxies of democracy affects neither the strength nor the direction of the estimated effect. To further investigate these results, we provide an alternative MRA specification including a more disaggregated classification of democracy indicators (see Table B.9 in the Appendix). The only positive statistically significant dummy relates to the Vanhanen index that has been shown to inflate the growth impact of democracy (Gründler \& Krieger, 2016). Once we exclude the very small sub-sample of studies relying on this indicator, in the last column of Table B.9, we find again that the use of alternative indicators does not impact the estimated growth effect of democracy.

Control variables. The largest block of rows in Table 5 reports the results relating to most of the control variables that scholars have used over the years to model the relationship between democracy and growth. The fact that almost all these coefficients are not significant is one of the main contributions of our analysis: different specifications of the augmented production function do not matter. Such outcome is remarkable, considering the extended attention that researchers have dedicated at growth regressions' covariates over the last decades. As a partial exception, controlling for Convergence positively affects the estimated effect of democracy on growth. Controlling instead for the growth rate of population decreases the value of the partial correlation between democracy and growth. Further, introducing a control for State Capacity - i.e. accounting for state capabilities in extracting rents, controlling their 
territory and providing public goods - increases the likelihood of finding a positive growth effect of democracy, although this covariate only appears in 3 studies and 31 models.

Geographical characteristics. The set of rows headlined as Geographical characteristics refers to the group of countries included in the primary studies and provides key insights on the growth effect of democracy: the sample of countries included in the analysis largely matter in predicting the direction and magnitude of the democracygrowth nexus. Following the regional classification used by the World Bank, we discover that democratic institutions have a strong and positive impact on economic growth in Sub-Saharan Africa ( $p<0.001$ and the largest coefficient of our MRA) and a slightly weaker impact $(\mathrm{p}<0.05)$ in High-income countries. If such regions are included within the samples, scholars are more likely to report the bright side of democracy. It is likely that in these countries democratic institutions intertwine with other institutional settings that support total output generation (Barro, 1991; Przeworski \& Limongi, 1993)

The opposite is true for South Asia $(\mathrm{p}<0.01$, the second-largest coefficient of Table 5), where democracy has a detrimental effect on growth. In this region, the theories of Huntington (1968) and Huntington \& Dominguez (1975) seem to prevail. Democracy, through increased demand for current consumption, reduces investment and hinders growth (Alesina et al., 1992; Persson \& Tabellini, 2003): here, authoritarian regimes can overcome such issue and help countries to reach their growth potential.

Our findings are mostly consistent with the theoretical and empirical literature on the subject. In South Asia, the lobbying power of some labour and industrial groups can lead to an inefficient investment allocation in democratic regimes promot- 
ing rent-seeking behaviours and, consequently, economic inefficiencies at the aggregate level. Against this background, authoritarian political elites can have the autonomy needed to promote economic growth without being restrained by rent-seekers' pressures (Krieckhaus, 2006).

Conversely, democracy enhances growth opportunities in Africa, where clientelism has historically been regarded as the region's main political economy feature (Wantchekon, 2003; Vicente \& Wantchekon, 2009) and the first cause behind the continent economic fragilities (Sandbrook \& Barker, 1985). Indeed, authoritarian regimes, which protect clientelistic interests and are less exposed to whistle-blowers arising from the civil society, are more likely to allow for corrupted politicians to plunder economic gains (Krieckhaus, 2006).

Finally, we find that including East Asian countries in the sample is not likely to affect the estimated relationship between democracy and growth. This is partially in contrast with the literature focusing on the positive impact of autocratic institutions on economic growth in East Asia (Krieckhaus, 2006). Accordingly to such literature, political elites, without the restraints imposed by democratic institutions, can commit to promoting rapid industrialisation over all other social objectives, hence fostering GDP growth (Cumings, 1984).

Overall, our results indicate that the strength of the nexus between democracy and growth is not ubiquitous. The impact of democratic institutions on economic growth is largely driven by regional-specific aspects, suggesting that, while democratic institutions are, on average, beneficial for economic growth, the effect depends on the countries considered in the analysis.

Time periods. The last set of rows reports a further important result of our analysis: not only space but also time matters. The coefficients of the dichotomous variables in- 
cluded in the bottom panel of Table 5 highlight that the period covered by the studies does matter for the sign of the relationship between democracy and growth. In particular, including the 1960s, 1970s or 2000s highly increases the probability of observing a negative relationship. This result is consistent with the fact that during the 1960s and part of the 1970s a relevant subset of democratising countries was experiencing the decolonisation phase. Thus, despite a formal increase in their democracy levels, they were also experiencing economic turmoils, hence low (or even negative) growth rates. The 2000s crises, as well the economic booming of autocratic China, drive instead the negative and significant coefficient of this dummy. Conversely, including the 1980s largely increases the probability of obtaining a positive relationship. The gradual stabilisation of the decolonisation processes, and the begin of the downturn of the Soviet block, could be interpreted as a golden age of the democracy and growth relationship.

Overall, the finding that the effect of democracy on growth is largely dependent on space and time characteristics of the underlying sample is consistent with the evidence on control variables: while convergence and population growth proxy the socio-economic development of a country, state capacity can be considered a measure of its overall political development. To better gauge the growth effect of democracy, time and space are essential components of the puzzle.

\subsubsection{Predicted values}

Based on our main model, reported in column (1) of Table 5, we provide some insights on the predicted effect of democracy on growth for a set of preferred study's characteristics. Predictions are based on our main model by setting equal to 1 only the value of the covariates we consider within our preferred set of study features. 
Our preferred specifications include panels averaged over sub-periods (panel avg) estimated through dynamic panel data techniques (DPD). We base our predictions on the most common measure of democracy within our sample (Polity) and include as control variables Convergence, Population, State capacity and Human capital. We separately consider each world region in alternative time spans: all available decades, all complete decades (1950-2009) and a set of time intervals that exclude earlier decades. The resulting predictions are shown in Table 6.

Table 6: Democracy and growth, predicted values for selected regions and periods

\begin{tabular}{lrrrrrrrr}
\hline & All regions & \multicolumn{1}{c}{ Africa } & East Asia & East Europe & Latin America & Middle East & South Asia & High-income \\
\hline All periods & $0.1212^{*}$ & $0.2039^{* * *}$ & -0.0007 & 0.0430 & 0.0162 & 0.0592 & -0.0835 & 0.0523 \\
& $(0.0558)$ & $(0.0582)$ & $(0.0719)$ & $(0.0626)$ & $(0.0607)$ & $(0.0606)$ & $(0.0721)$ & $(0.0583)$ \\
$1950-2009$ & 0.0660 & $0.1487^{* * *}$ & -0.0559 & -0.0122 & -0.0390 & 0.0040 & $-0.1387^{*}$ & -0.0029 \\
& $(0.0403)$ & $(0.0440)$ & $(0.0591)$ & $(0.0492)$ & $(0.0470)$ & $(0.0478)$ & $(0.0629)$ & $(0.0439)$ \\
$1960-2009$ & 0.0710 & $0.1537^{* * *}$ & -0.0509 & -0.0072 & -0.0340 & 0.0090 & $-0.1337^{*}$ & 0.0021 \\
& $(0.0367)$ & $(0.0407)$ & $(0.0577)$ & $(0.0466)$ & $(0.0440)$ & $(0.0449)$ & $(0.0599)$ & $(0.0409)$ \\
$1970-2009$ & $0.1315^{* * *}$ & $0.2143^{* * *}$ & 0.0096 & 0.0533 & 0.0265 & 0.0695 & -0.0732 & 0.0626 \\
& $(0.0377)$ & $(0.0415)$ & $(-0.0583)$ & $(0.0474)$ & $(0.0448)$ & $(0.0457)$ & $(0.0605)$ & $(0.0417)$ \\
$1980-2009$ & $0.1739^{* * *}$ & $0.2566^{* * *}$ & 0.0520 & 0.0957 & 0.0689 & $0.1119^{*}$ & -0.0308 & 0.1050 \\
& 0.0354 & 0.0394 & $(0.0567)$ & $(0.0454)$ & $(0.0428)$ & $(0.0436)$ & $(0.0590)$ & $(0.0395)$ \\
\hline
\end{tabular}

Notes: Predicted values based on column (1) Tab. 5. The following variables are set equal to 1: Panel (avg), DPD, Polity, Convergence, Population, State capacity, Human capital. Standard errors in parentheses.

Significance levels $* * * 0.001 * * 0.01 * 0.05$

This analysis confirms that the effect of democracy on growth is positive and statistically significant. Yet, the economic significance of such effect is rather small (see the guidelines for interpreting meta-analytical coefficients proposed by Doucouliagos, 2011, p. 11). The predicted effect is larger when the 1950s and 1960s are excluded from the sample. The effect of democracy and growth is not homogeneous across regions nor periods. For analyses including Africa, the strength of the association between democracy and growth is positive and moderate in size. A positive effect is also found for the Middle East, albeit only in the most recent time interval (19802009) and smaller in magnitude. Conversely, for analyses including South Asia, the effect is negative and small when the 1950s and 1960s are also investigated. In the remaining regions, no coefficient is statistically significant at 5\% level. Overall, Table 
6 confirms a very large variability in the predicted values across regions and decades. Therefore, the overall small effect might be driven by region-specific and time-specific effects working in opposing directions.

\subsection{Publication Bias}

Since the seminal contribution of De Long \& Lang (1992), publication bias has been recognised as another threat to empirical economics (Stanley, 2005). When articles failing to report statistically significant results are kept in the file drawer (Rosenthal, 1979) or routinely rejected by editors and referees, the distribution of effect sizes available on a given relationship would be distorted. As a result, metaanalytical estimates might over- or under-estimate the true effect, which might result in reporting a statistically significant relationship when there is none.

To address this issue, researchers have developed statistical techniques to identify and, if necessary, correct, for publication bias (see Rothstein et al., 2006; Stanley, 2008). Among these, the most common tool is the visual inspection of funnel plots, which show the effect size estimates from individual studies against an inverted measure of study size or precision (standard errors in Figure 3). In the absence of publication bias, the graph should resemble an inverted funnel; low-sample studies would scatter more widely at the bottom, while large-sample studies would converge towards the true effect.

Yet, the visual investigation of the funnel plot might be subjective (Terrin et al., 2005) and, as in Figure 3, complex to interpret when the meta-analytical sample is large. Therefore, to formally investigate funnel plots asymmetry, researchers usually test $H_{0}: \beta_{1}=0$ in a regression of the effect size on a constant term and the standard error of the effect size (i.e. $y_{i}=\beta_{0}+\beta_{1} S E_{i}$ ) where the error structure might be either additive or multiplicative (Sterne \& Egger, 2006). If there is a relationship between 
Figure 3: Democracy and growth: funnel plot

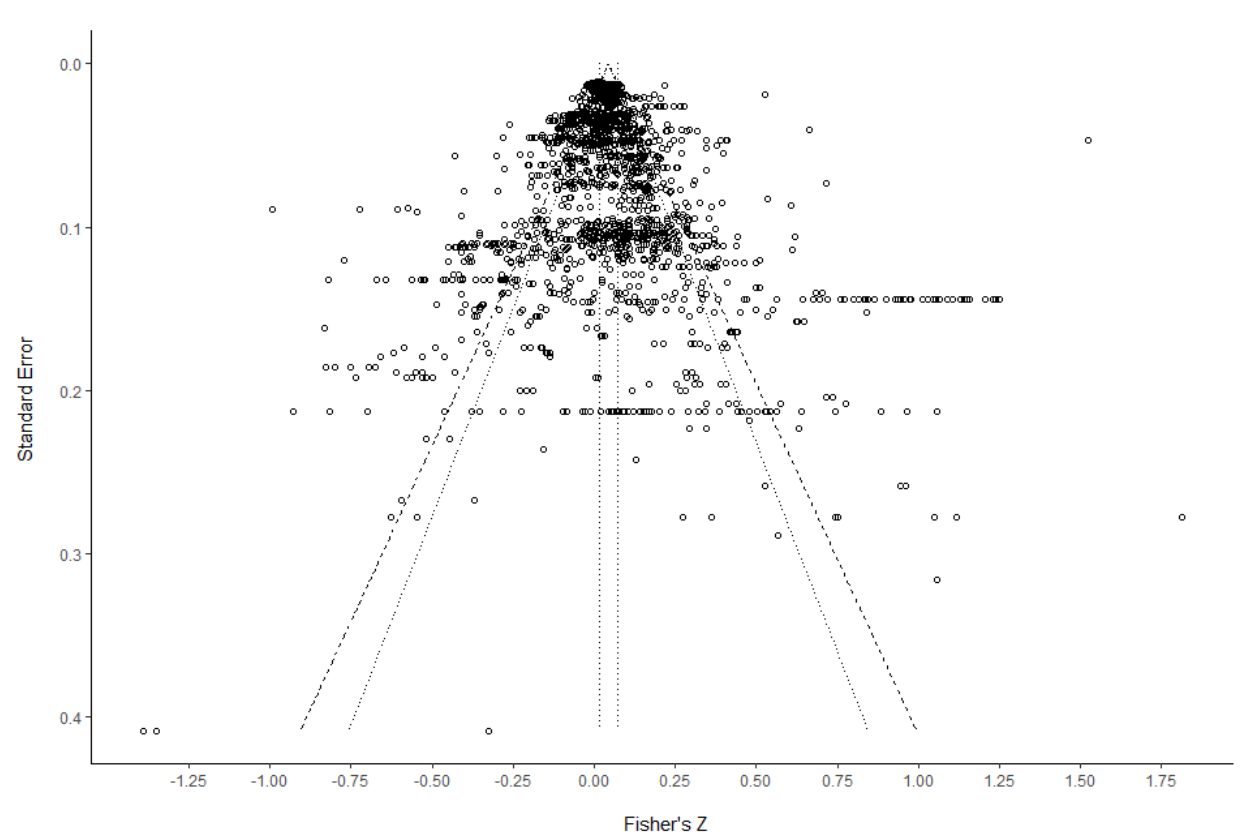

The outer dashed (dotted) diagonal lines represent the 99\% (95\%) confidence interval region. The inner vertical lines represents the $95 \%$ confidence interval region of the RE ML estimate of the effect of democracy on growth (Table 2).

the observed outcomes and the chosen measure of study size or precision, this might imply asymmetry in the funnel plot. Therefore, when the null hypothesis of the funnel asymmetry test (FAT) is rejected, the estimates might suffer from publication bias (Egger et al., 1997; Stanley, 2005). This does not appear to be the case in the democracy and growth literature. Panel A of Table 7 shows that the null hypothesis of no publication bias $\left(\hat{\beta}_{1}=0\right)$ is not rejected in all three FAT tests.

Stanley (2008) shows that testing $H_{0}: \beta_{0}=0$ can provide information on whether there exists a genuine empirical effect beyond the reach of selective reporting bias (Precision Effect Test, PET). Intuitively, the intercept of a regression of the effect sizes on their standard errors should provide the effect size of a perfect study (with standard errors equal zero) once the potential publication bias is accounted for. However, Stanley \& Doucouliagos (2014) show that $\hat{\beta}_{0}$, as estimated by the PET test, 
Table 7: Publication bias: tests

(a) Panel A: FAT tests, no additional covariates

\begin{tabular}{cccc}
\hline & $\begin{array}{c}\text { RE ML } \\
(\text { s.e. })\end{array}$ & $\begin{array}{c}\text { RE } \\
\text { (clustered s.e.) }\end{array}$ & $\begin{array}{c}\text { UWLS } \\
\text { (clustered s.e.) }\end{array}$ \\
\hline & FAT-PET & FAT-PET & FAT-PET \\
\hline$\beta_{0}$ & $0.0278^{+}$ & 0.0230 & $0.0273^{* * *}$ \\
& $(0.0174)$ & $(0.0177)$ & $(0.0061)$ \\
$\beta_{1}$ & 0.1851 & 0.3823 & 0.3140 \\
& $(0.1282)$ & $(0.4617)$ & $(0.3062)$ \\
\hline
\end{tabular}

(b) Panel B: PEESE tests

\begin{tabular}{cccc}
\hline & $\begin{array}{c}\text { RE ML } \\
\text { (s.e.) }\end{array}$ & $\begin{array}{c}\text { RE } \\
\text { (clustered s.e.) }\end{array}$ & $\begin{array}{c}\text { UWLS } \\
\text { (clustered s.e.) }\end{array}$ \\
\hline & PEESE & PEESE & PEESE \\
\hline$\beta_{0}$ & $0.0394^{* *}$ & - & $0.0321^{* * *}$ \\
& $(0.0149)$ & - & $(0.0041)$ \\
$\beta_{1}$ & 0.4825 & - & 2.2063 \\
& $(0.5762)$ & - & $(2.328)$ \\
\hline
\end{tabular}

(c) Panel C: FAT tests, additional covariates (not reported) as in Table 5

\begin{tabular}{cccc}
\hline & $\begin{array}{c}\text { RE ML } \\
\text { (s.e.) }\end{array}$ & $\begin{array}{c}\text { RE } \\
\text { (clustered s.e.) }\end{array}$ & $\begin{array}{c}\text { UWLS } \\
\text { (clustered s.e.) }\end{array}$ \\
\hline \multirow{2}{*}{$\beta_{0}$} & FAT & FAT & FAT \\
& $-0.1067^{*}$ & -0.0724 & -0.0661 \\
$\beta_{1}$ & $(0.0427)$ & $(0.0964)$ & $(0.0600)$ \\
& $\left(0.4077^{+}\right.$ & -0.0273 & 0.3980 \\
& $(0.2265)$ & $(0.6475)$ & $(0.4129)$ \\
\hline
\end{tabular}

Notes: Standard errors in parentheses, as indicated in columns' headers. The sample is composed by 2047 observations (188 studies). The first column reports the estimate of the Random Effects (Multi-Level) estimation (RE ML); the second column of the Random Effect model (RE); and the third column of the UWLS estimates.

Significance levels $* * * 0.001 * * 0.01 * 0.05+0.10$. The latter is reported as recommended by Stanley (2017). 
tends to under-estimate the true effect. Replacing the effect size's standard error with its variance $\left(v_{i}^{2}\right)$ reduces the bias in the intercept, a test known as Precision Effect Estimate with Standard Error (PEESE). Therefore, when there is evidence of a genuine effect, PEESE should be used; otherwise, the corrected effect is best estimated by FAT tests. To choose whether employing the FAT or the PEESE test, Stanley (2017) recommends testing for $H_{0}: \beta_{0} \leq 0$ at the $10 \%$ significance level.

The results of the PEESE estimates are reported in Panel B of Table 7. Overall, except for the random effect model, the three-steps FAT-PET-PEESE procedure, which has become the cornerstone of publication bias analysis in economics (see Alinaghi \& Reed, 2018, for a list of references), shows that there exist a relationship between democracy and growth over and beyond publication bias. Importantly, the PEESE estimates are not statistically different from any of the estimates of our metaanalysis (Table 2).

Finally, Panel C of Table 7 shows that there is no strong evidence of differential publication bias associated with other moderator variables (our covariates). It replicates the FAT procedure (Table 7, Panel A) with the addition of the same covariates (not reported) included in the meta-regression analysis (Table 5). Such a model addresses "possible interaction of funnel plot asymmetry and moderator variables by simultaneously fitting a meta-regression and a publication bias model" (Stanley \& Doucouliagos, 2014, p. 75) and confirms that there is no prejudice against the null hypothesis in the democracy and growth literature. ${ }^{26}$

\footnotetext{
${ }^{26}$ When additional covariates are included, the intercept no longer provides information on whether there exists an effect beyond publication bias. Therefore, the PET-PEESE procedure is not estimated when additional covariates are included.
} 


\section{Conclusion}

The relationship between democracy and economic growth has long been investigated in the political science and the economic literature both from a theoretical and empirical perspective. Starting in the early 1990s, regression analysis has been increasingly applied to the empirical investigations of institutional determinants of economic growth. The findings of this early literature have been, at best, mixed. Further attempts moved their focus mostly on identification strategies, proposing alternative solutions to the embedded endogeneity of institutions (e.g. Acemoglu et al., 2001). This led to a further diversification of model specifications, estimation techniques and measures of democracy. Overall, such process led to increasing evidence of a positive effect of democracy on growth at least among economists, but a definitive consensus was far from being reached.

By adopting a meta-analytical framework, we try to shed lights on this relationship. Based on a hierarchical sample of 188 studies containing 2047 observations (the largest sample of effect sizes dealing with such an issue), our analysis suggests that democracy positively correlates to economic growth over and beyond publication bias. We then compare the magnitude with the observed correlation between human capital and growth in the appropriate sub-sample of studies. Our analysis suggests the growth effect of democracy is about one-third of the comparable effect of human capital.

Further, our results also suggest that findings from more recent papers, not surveyed in Doucouliagos \& Ulubaşoğlu (2008), uncover a stronger democracy-growth nexus.

Our meta-analyses also document a high degree of between-studies heterogeneity - in line with analogous applications in the economic literature (see Ioannidis et al., 
2017 ) - that we investigated by adopting meta-regression techniques. Effect sizes are mostly driven by spatial and time differences in the sample, indicating that the democracy and growth nexus is largely dependent on the world's regions and periods considered.

We find that the adoption of alternative measures of democracy does not substantially affect the outcome of the analysis. Further, most of the control variables included in the papers to account for potential confounding effects, do not impact the reported point estimates, except for Population, Convergence and State Capacity. The use of averages in a panel data setting positively impacts the uncovered growth effect of democracy, while the inclusion of non-linear terms negatively affects it. Overall, estimation techniques other than OLS do not systematically affect the outcome of the uncovered relation between democracy and growth.

Finally, predicted values from our preferred specification support our findings: the effect of democracy on growth, which is small in the full sample, varies across world regions and time intervals, being larger once periods beyond 1970s are included. In particular, the predicted effect size is positive and moderate for Africa; negative and small for South Asia.

Overall, after digging into more than 2000 regressions within almost 200 papers, we show that democracy does affect growth, even if the effect is small and not ubiquitous across space and time, thus confirming, at least from an economic perspective, the famous quote by Winston Churchill, "[m]any forms of Government have been tried and will be tried in this world of sin and woe. No one pretends that democracy is perfect or all-wise. Indeed, it has been said that democracy is the worst form of government except for all those other forms that have been tried from time to time" ${ }^{27}$

\footnotetext{
${ }^{27}$ W. Churchill, Speech in the House of Commons (11 November 1947), published in The Official Report, House of Commons (5th Series), 11 November 1947, vol. 444.
} 


\section{Acknowledgements}

Acknowledgements temporarily removed for peer-review. 


\section{References}

\section{References}

Acemoglu, D., Johnson, S., \& Robinson, J. A. (2001). The colonial origins of comparative development: An empirical investigation. American Economic Review, 91, 1369-1401.

Acemoglu, D., Johnson, S., Robinson, J. A., \& Yared, P. (2008). Income and democracy. American Economic Review, 98, 808-842.

Acemoglu, D., Naidu, S., Restrepo, P., \& Robinson, J. A. (2019). Democracy does cause growth. Journal of Political Economy, 127, 47-100.

Alesina, A., Cohen, G. D., \& Roubini, N. (1992). Macroeconomic policy and elections in oecd democracies. Economics \& Politics, 4, 1-30.

Alesina, A., \& Perotti, R. (1994). The political economy of growth: a critical survey of the recent literature. The World Bank Economic Review, 8, 351-371.

Alinaghi, N., \& Reed, W. R. (2018). Meta-analysis and publication bias: How well does the fat-pet-peese procedure work? Research synthesis methods, 9, 285-311.

Barro, R. J. (1991). Economic growth in a cross section of countries. The quarterly journal of economics, 106, 407-443.

Barro, R. J. (1996). Democracy and growth. Journal of economic growth, 1, 1-27.

Barro, R. J. (1999). Determinants of democracy. Journal of Political economy, 107, S158-S183.

Barro, R. J. (2001). Human capital and growth. American economic review, 91, $12-17$. 
Barro, R. J. (2003). Determinants of economic growth in a panel of countries. Annals of economics and finance, 4, 231-274.

Barro, R. J., \& Sala-i-Martin, X. (1992). Convergence. Journal of political Economy, $100,223-251$.

Baum, M. A., \& Lake, D. A. (2003). The political economy of growth: Democracy and human capital. American Journal of Political Science, 47, 333-347.

Benos, N., \& Zotou, S. (2014). Education and economic growth: A meta-regression analysis. World Development, 64, 669-689.

Bollen, K. A. (1998). Cross-national indicators of liberal democracy, 1950-1990. Inter-university Consortium for Political and Social Research.

Borenstein, M., Hedges, L. V., Higgins, J., \& Rothstein, H. R. (2010). A basic introduction to fixed-effect and random-effects models for meta-analysis. Research Synthesis Methods, 1, 97-111.

Brunetti, A. (1997). Political variables in cross-country growth analysis. Journal of Economic Surveys, 11, 163-190.

Ciccone, A., \& Papaioannou, E. (2009). Human capital, the structure of production, and growth. The Review of Economics and Statistics, 91, 66-82.

Cohen, D., \& Soto, M. (2007). Growth and human capital: good data, good results. Journal of economic growth, 12, 51-76.

Cumings, B. (1984). The origins and development of the northeast asian political economy: industrial sectors, product cycles, and political consequences. International Organization, 38, 1-40. 
Dahlum, S., \& Knutsen, C. H. (2017). Do democracies provide better education? revisiting the democracy-human capital link. World Development, 94, 186-199.

Dauvin, M., \& Guerreiro, D. (2017). The paradox of plenty: A meta-analysis. World Development, 94, 212-231.

De Long, J. B., \& Lang, K. (1992). Are all economic hypotheses false? Journal of Political Economy, 100, 1257-1272.

Doucouliagos, H., \& Ulubaşoğlu, M. A. (2008). Democracy and economic growth: a meta-analysis. American Journal of Political Science, 52, 61-83.

Doucouliagos, H. C. (2011). How large is large? Preliminary and relative guidelines for interpreting partial correlations in economics. Technical Report Deakin University, School of Accounting, Economics and Finance. URL: https://www.deakin. edu.au/__data/assets/pdf_file/0003/408576/2011_5.pdf.

Egger, M., Smith, G. D., Schneider, M., \& Minder, C. (1997). Bias in meta-analysis detected by a simple, graphical test. $B m j, 315,629-634$.

Gerring, J., Bond, P., Barndt, W. T., \& Moreno, C. (2005). Democracy and economic growth: A historical perspective. World Politics, 57, 03.

Gründler, K., \& Krieger, T. (2016). Democracy and growth: Evidence from a machine learning indicator. European Journal of Political Economy, 45, 85-107.

Gründler, K., \& Krieger, T. (2018). Machine Learning Indices, Political Institutions, and Economic Development. Technical Report CESifo Group Munich. URL: https: //www . econstor.eu/bitstream/10419/176949/1/cesifo1_wp6930.pdf.

Gunby, P., Jin, Y., \& Reed, W. R. (2017). Did fdi really cause chinese economic growth? a meta-analysis. World Development, 90, 242-255. 
Gundlach, E., \& Paldam, M. (2009). A farewell to critical junctures: Sorting out longrun causality of income and democracy. European Journal of Political Economy, $25,340-354$.

Hazama, Y. (2008). The Political Economy of Growth: A Review. Technical Report Institute of Developing Economies, Japan External Trade Organization (JETRO). URL: https://www .ide.go.jp/English/Publish/Download/Dp/141.html.

Hedges, L. V., \& Vevea, J. L. (1998). Fixed-and random-effects models in metaanalysis. Psychological methods, 3, 486.

Helliwell, J. F. (1994). Empirical linkages between democracy and economic growth. British Journal of Political Science, 24, 02.

Heo, U., \& Tan, A. C. (2001). Democracy and economic growth: A causal analysis. Comparative Politics, (pp. 463-473).

Higgins, J., Thompson, S. G., Deeks, J. J., Altman, D. G. et al. (2003). Measuring inconsistency in meta-analyses. British medical journal, 327, 557-560.

Hodgson, G. M. (2006). What are institutions? Journal of Economic Issues, 40, $1-24$.

Hopewell, S., Clarke, M., \& Mallett, S. (2005). Grey literature and systematic reviews. Publication bias in meta-analysis: Prevention, assessment and adjustments, (pp. $48-72)$.

Huntington, S. P. (1968). Political order in changing societies. Yale University Press.

Huntington, S. P., \& Dominguez, J. I. (1975). Political development. Handbook of political science, 3, 1-114. 
Ioannidis, J. P., Stanley, T. D., \& Doucouliagos, H. (2017). The power of bias in economics research. The Economic Journal, 127, F236-F265.

Iwasaki, I., \& Tokunaga, M. (2014). Macroeconomic impacts of fdi in transition economies: a meta-analysis. World Development, 61, 53-69.

Jiang, W. (2017). Have instrumental variables brought us closer to the truth. The Review of Corporate Finance Studies, 6, 127-140.

Klomp, J., \& de Haan, J. (2009). Political institutions and economic volatility. European Journal of Political Economy, 25, 311-326.

Knutsen, C. H. (2011). Democracy, dictatorship and protection of property rights. The Journal of Development Studies, 47, 164-182.

Knutsen, C. H. (2012). Democracy and economic growth: A survey of arguments and results. International Area Studies Review, 15, 393-415.

Kong, T. (2007). A selective review of recent developments in the economic growth literature. Asian-Pacific Economic Literature, 21, 1-33.

Konstantopoulos, S. (2011). Fixed effects and variance components estimation in three-level meta-analysis. Research Synthesis Methods, 2, 61-76.

Krieckhaus, J. (2006). Democracy and economic growth: how regional context influences regime effects. British Journal of Political Science, 36, 317-340.

Lipset, S. M. (1959). Some social requisites of democracy: Economic development and political legitimacy. American political science review, 53, 69-105.

Madsen, J. B., Raschky, P. A., \& Skali, A. (2015). Does democracy drive income in the world, 1500 2000? European Economic Review, 78, 175-195. 
Marshall, M. G., \& Jaggers, K. (2002). Polity IV project: Political regime characteristics and transitions, 1800-2002. Center for Systemic Peace.

Minier, J. A. (1998). Democracy and growth: Alternative approaches. Journal of economic growth, 3, 241-266.

Murtin, F., \& Wacziarg, R. (2014). The democratic transition. Journal of Economic Growth, 19, 141-181.

North, D. C. (1990). Institutions, institutional change and economic performance. Cambridge university press.

North, D. C. (1994). Institutions matter. Technical Report University Library of Munich, Germany. URL: https://econwpa.ub.uni-muenchen.de/econ-wp/eh/ papers/9411/9411004.pdf.

Olson, M. (1982). The rise and decline of nations: Economic growth, stagflation, and economic rigidities. New Haven and London: Yale University Press.

Olson, M. (1993). Dictatorship, democracy, and development. American Political Science Review, 87, 567-576.

Pemstein, D., Meserve, S. A., \& Melton, J. (2010). Democratic compromise: A latent variable analysis of ten measures of regime type. Political Analysis, 18, 426-449. doi:10.1093/pan/mpq020.

Persson, T., \& Tabellini, G. (2003). Do Electoral Cycles Differ Across Political Systems?. Technical Report IGIER (Innocenzo Gasparini Institute for Economic Research), Bocconi University. URL: http://www.igier.unibocconi.it/folder. php?vedi=1175\&tbn=albero\&id_folder $=4878$. 
Przeworski, A. (2000). Democracy and development: Political institutions and wellbeing in the world, 1950-1990 volume 3. Cambridge University Press.

Przeworski, A., \& Limongi, F. (1993). Political regimes and economic growth. The journal of economic perspectives, 7, 51-69.

Rivera-Batiz, F. L. (2002). Democracy, governance, and economic growth: theory and evidence. Review of Development Economics, 6, 225-247.

Rodrik, D., \& Wacziarg, R. (2005). Do democratic transitions produce bad economic outcomes? The American economic review, 95, 50-55.

Rosenthal, R. (1979). The file drawer problem and tolerance for null results. Psychological bulletin, 86, 638 .

Rothstein, H. R., Sutton, A. J., \& Borenstein, M. (2006). Publication bias in metaanalysis: Prevention, assessment and adjustments. John Wiley \& Sons.

Saint-Paul, G., \& Verdier, T. (1993). Education, democracy and growth. Journal of development Economics, 42, 399-407.

Sala-i-Martin, X. (1997). I just ran two million regressions. The American Economic Review, 87, 178-183.

Sandbrook, R., \& Barker, J. (1985). The politics of Africa's economic stagnation. Cambridge University Press.

Sirowy, L., \& Inkeles, A. (1990). The effects of democracy on economic growth and inequality: A review. Studies in Comparative International Development, 25, 126157. 
Stanley, T. D. (2001). Wheat from chaff: Meta-analysis as quantitative literature review. The Journal of Economic Perspectives, 15, 131-150.

Stanley, T. D. (2005). Beyond publication bias. Journal of Economic Surveys, 19, $309-345$.

Stanley, T. D. (2008). Meta-regression methods for detecting and estimating empirical effects in the presence of publication selection*. Oxford Bulletin of Economics and statistics, 70, 103-127.

Stanley, T. D. (2017). Limitations of pet-peese and other meta-analysis methods. Social Psychological and Personality Science, 8, 581-591.

Stanley, T. D., \& Doucouliagos, H. (2014). Meta-regression approximations to reduce publication selection bias. Research Synthesis Methods, 5, 60-78.

Stanley, T. D., \& Doucouliagos, H. (2015). Neither fixed nor random: weighted least squares meta-analysis. Statistics in medicine, 34, 2116-2127.

Stanley, T. D., \& Doucouliagos, H. (2017). Neither fixed nor random: Weighted least squares meta-regression. Research synthesis methods, 8, 19-42.

Stanley, T. D., \& Jarrell, S. B. (1989). Meta-regression analysis: A quantitative method of literature surveys. Journal of economic surveys, 3, 161-170.

Sterne, J. A., \& Egger, M. (2006). Regression methods to detect publication and other bias in meta-analysis. In Publication Bias in Meta-Analysis chapter 6. (pp. 99-110). John Wiley \& Sons, Ltd.

Stevens, J. R., \& Taylor, A. M. (2009). Hierarchical dependence in meta-analysis. Journal of Educational and Behavioral Statistics, 34, 46-73. 
Tavares, J., \& Wacziarg, R. (2001). How democracy affects growth. European economic review, 45, 1341-1378.

Terrin, N., Schmid, C. H., \& Lau, J. (2005). In an empirical evaluation of the funnel plot, researchers could not visually identify publication bias. Journal of clinical epidemiology, 58, 894-901.

Thompson, S. G., \& Sharp, S. J. (1999). Explaining heterogeneity in meta-analysis: a comparison of methods. Statistics in medicine, 18, 2693-2708.

Vanhanen, T. (2000). A new dataset for measuring democracy, 1810-1998. Journal of Peace Research, 37, 251-265.

Vicente, P. C., \& Wantchekon, L. (2009). Clientelism and vote buying: lessons from field experiments in african elections. Oxford Review of Economic Policy, 25, 292305.

Viechtbauer, W. (2005). Bias and efficiency of meta-analytic variance estimators in the random-effects model. Journal of Educational and Behavioral Statistics, 30, 261-293.

Viechtbauer, W. (2010). Conducting meta-analyses in $\mathrm{r}$ with the metafor package. $J$ Stat Softw, 36, 1-48.

Wantchekon, L. (2003). Clientelism and voting behavior: Evidence from a field experiment in benin. World politics, 55, 399-422.

Weede, E. (1983). The impact of democracy on economic growth: some evidence from cross-national analysis. Kyklos, 36, 21-39. 


\section{Appendix A. The meta-sample}

Table A.1: The meta-analytical sample: additional information

\begin{tabular}{|c|c|c|c|c|c|c|c|}
\hline Study & Coefficients & Mean Z & $\mathrm{SD} \mathrm{Z}$ & Period & Countries & Includes HC & Publication type \\
\hline Abdelkader (2015) & 3 & 0.3830 & 0.0306 & $1972-2013$ & 1 & Yes & working paper \\
\hline Abida et al. (2015) & 3 & -0.1096 & 0.0000 & $1980-2012$ & 3 & No & journal article \\
\hline Acemoglu et al. (2008) & 2 & 0.0885 & 0.0123 & $1960-2000$ & 134 & No & journal article \\
\hline Acemoglu et al. (2019) & 90 & 0.0329 & 0.0173 & $1960-2010$ & 175 & No & journal article \\
\hline Adams \& Klobodu (2016) & 3 & 0.0108 & 0.0928 & $1970-2011$ & 33 & Yes & journal article \\
\hline Adom (2016) & 44 & 0.8592 & 0.2684 & $1962-2012$ & 1 & No & working paper \\
\hline Aghion et al. (2007) & 9 & 0.0806 & 0.0688 & $1980-2000$ & 148 & No & working paper \\
\hline Ahmad \& Hall (2017) & 8 & 0.0237 & 0.0301 & 1984-2007 & 58 & Yes & journal article \\
\hline Aisen \& Veiga (2013) & 4 & -0.0476 & 0.0526 & 1960-2004 & 113 & Yes & journal article \\
\hline Albornoz-Crespo \& Dutta (2007) & 8 & -0.0637 & 0.4098 & $1960-2000$ & 18 & Yes & working paper \\
\hline Alesina \& Rodrik (1994) & 2 & -0.0085 & 0.0239 & 1970-1985 & 41 & Yes & journal article \\
\hline Alesina et al. (1996) & 1 & 0.0424 & NA & 1960-1985 & 98 & Yes & working paper \\
\hline Ali \& Crain (2001a) & 8 & 0.0088 & 0.1158 & 1975-1994 & 91 & Yes & unpubllished \\
\hline Ali \& Crain (2001b) & 2 & -0.0007 & 0.0202 & 1975-1989 & 91 & Yes & journal article \\
\hline Ali (1997) & 2 & 0.0007 & 0.0202 & $1975-1990$ & 91 & Yes & journal article \\
\hline Ali (2003) & 16 & -0.0344 & 0.2358 & 1975-1994 & 91 & Yes & journal article \\
\hline Almeida \& Ferreira (2002) & 3 & -0.0141 & 0.0537 & 1970-1990 & 138 & Yes & journal article \\
\hline Alpalhão (2019) & 72 & 0.0350 & 0.0145 & $1961-2016$ & 148 & No & unpubllished \\
\hline Amir-ud Din \& Khan (2017) & 10 & 0.0582 & 0.3556 & $1963-2016$ & 1 & No & journal article \\
\hline Antič (2004) & 2 & -0.0197 & 0.0251 & $1951-1990$ & 141 & Yes & journal article \\
\hline Arfaoui et al. (2016) & 2 & -0.2305 & 0.1324 & $1980-2014$ & 1 & No & journal article \\
\hline Assane \& Pourgerami (1994) & 8 & 0.0489 & 0.0349 & 1980-1989 & 33 & No & journal article \\
\hline Assiotis \& Sylwester (2014) & 29 & 0.0808 & 0.0888 & 1984-2007 & 155 & No & journal article \\
\hline Assiotis \& Sylwe & 37 & 0.1643 & 0.1105 & $1986-2010$ & 118 & Yes & journal article \\
\hline Aziz \& Ahmad (2018) & 12 & -0.1941 & 0.2080 & 2000-2009 & 126 & Yes & working paper \\
\hline Baklouti \& Boujelbene (2015) & 1 & -0.2966 & NA & 1998-2011 & 12 & Yes & l article \\
\hline Baklouti \& Boujelbene (2018) & 1 & -0.4036 & NA & 1998-2011 & 12 & Yes & journal article \\
\hline Barro \& Lee (1993) & 2 & 0.0048 & 0.2858 & $1965-1985$ & 89 & Yes & working paper \\
\hline Barro (1996) & 9 & 0.2149 & 0.0755 & $1965-1990$ & 90 & Yes & working paper \\
\hline Barro (1996b) & 3 & -0.0068 & 0.1166 & 1960-1990 & 84 & Yes & journal article \\
\hline Barro (2000) & 2 & 0.1127 & 0.0078 & 1965-1995 & 97 & Yes & journal article \\
\hline Bataka (2019) & 12 & 0.2068 & 0.0390 & $1980-2015$ & 40 & Yes & journal article \\
\hline Baum \& Lake (2003) & 2 & -0.0073 & 0.0150 & 1967-1997 & 128 & Yes & journal article \\
\hline Bhalla (1997) & 17 & 0.2971 & 0.0556 & 1973-1990 & 86 & Yes & book \\
\hline Bleaney \& Nishiyama (2002) & 4 & 0.4405 & 0.0545 & $1965-1990$ & 70 & Yes & journal article \\
\hline Bluedorn (2001) & 4 & -0.1210 & 0.0448 & 1960-1990 & 78 & Yes & journal article \\
\hline Boko (2002) & 2 & 0.2418 & 0.0135 & 1971-1999 & 20 & No & journal article \\
\hline Bornscheir \& Sc & 5 & 0.1430 & 0.1369 & 1968-1991 & 102 & Yes & unpubllished \\
\hline Bougharriou et al. (2019) & 2 & 0.1224 & 0.0636 & $2002-2013$ & 16 & No & journal article \\
\hline Brueckner et al. (2018) & 11 & -0.0225 & 0.0602 & $1970-2010$ & 126 & Yes & working paper \\
\hline Butkiewicz \& Yanikkaya (2006) & 52 & 0.0891 & 0.0830 & 1970-1999 & 114 & Yes & journal article \\
\hline Butkiewicz \& Yanikkaya (2007) & 7 & -0.0626 & 0.0432 & 1970-1999 & 106 & Yes & journal article \\
\hline Cavallo \& Cavallo (2010) & 32 & -0.0111 & 0.0435 & 1970-2004 & 78 & Yes & journal article \\
\hline Chan et al. (2017) & 1 & -0.0292 & NA & 1984-2014 & 113 & No & journal article \\
\hline Chatterji (1998) & 5 & 0.2159 & 0.0326 & $1960-1985$ & 81 & Yes & journal article \\
\hline Chen (2003) & 4 & 0.5358 & 0.1926 & 1970-1992 & 54 & Yes & journal article \\
\hline Chen et al. (2019) & 6 & 0.0472 & 0.0045 & 1987-2009 & 147 & No & unpubllished \\
\hline Chousa et al. (2006) & 1 & 0.1700 & NA & 1994-2002 & 55 & No & working paper \\
\hline Collier (1999) & 1 & 0.1834 & NA & $1960-1990$ & 94 & No & unpubllished \\
\hline Collier (2000) & 13 & 0.0950 & 0.0737 & $1960-1990$ & 94 & Yes & journal article \\
\hline Combes et al. (2019) & 15 & 0.1086 & 0.0274 & 1980-2012 & 70 & Yes & journal article \\
\hline Comeau (2003) & 11 & -0.3143 & 0.1980 & 1972-1989 & 82 & Yes & journal article \\
\hline Corujo \& Simões (2012) & 1 & -0.8299 & NA & $1960-2001$ & 1 & Yes & journal article \\
\hline Dasgupta et al. (2013) & 2 & 0.0075 & 0.0077 & $1980-2010$ & 1 & Yes & working paper \\
\hline Dawson (1998) & 2 & 0.0944 & 0.0141 & $1975-1990$ & 85 & Yes & journal article \\
\hline
\end{tabular}




\begin{tabular}{|c|c|c|c|c|c|c|c|}
\hline Study & Coefficients & Mean Z & $\mathrm{SD} \mathrm{Z}$ & Period & Countries & Includes $\mathrm{HC}$ & Publication type \\
\hline De Haan \& Siermann (1995) & 13 & 0.0667 & 0.1044 & $1973-1988$ & 96 & No & journal article \\
\hline De Haan \& Siermann (1996a) & 2 & 0.0351 & 0.0317 & 1961-1992 & 110 & No & journal article \\
\hline De Haan \& Siermann (1996b) & 10 & 0.1085 & 0.3463 & $1963-1988$ & 97 & No & journal article \\
\hline De la Croix \& Delavallade (2011) & 7 & -0.0536 & 0.0159 & $1994-2004$ & 62 & No & journal article \\
\hline De Luca et al. (2015) & 2 & 0.1012 & 0.0191 & $1960-2003$ & 129 & No & journal article \\
\hline Deana \& Gamba (2008) & 2 & -0.0163 & 0.0220 & $1955-2000$ & 183 & No & working paper \\
\hline Decker \& Lim (2008) & 52 & 0.0346 & 0.0681 & $1995-2002$ & 128 & No & journal article \\
\hline Dias \& Tebaldi (2012) & 11 & 0.0343 & 0.0175 & $1965-2005$ & 61 & Yes & journal article \\
\hline Diebolt et al. (2013) & 5 & -0.2835 & 0.0975 & $1990-2000$ & 85 & No & journal article \\
\hline Doucouliagos \& Ulubasoglu (2006) & 2 & 0.0039 & 0.0450 & $1970-1999$ & 82 & Yes & journal article \\
\hline Drury et al. (2006) & 3 & -0.0216 & 0.0293 & $1982-1997$ & 94 & No & journal article \\
\hline Durham (1999) & 18 & 0.0465 & 0.1087 & 1960-1989 & 105 & Yes & journal article \\
\hline Emara \& Jhonsa (2014) & 2 & 0.4648 & 0.3566 & 2009-2009 & 189 & No & working paper \\
\hline Fedderke \& Klitgaard (1998) & 7 & 0.0931 & 0.1817 & $1960-1985$ & 113 & Yes & journal article \\
\hline Feng (1995) & 12 & 0.0966 & 0.1713 & $1982-1988$ & 19 & No & journal article \\
\hline Feng (1996) & 6 & 0.3731 & 0.1375 & 1960-1992 & 40 & Yes & journal article \\
\hline Feng (1997) & 5 & -0.2225 & 0.0823 & $1960-1980$ & 96 & Yes & journal article \\
\hline Fidrmuc (2003) & 42 & 0.1045 & 0.3125 & $1996-2000$ & 25 & Yes & journal article \\
\hline Flachaire et al. (2014) & 4 & 0.0221 & 0.0756 & $1975-2005$ & 79 & Yes & journal article \\
\hline Fosu (2008) & 15 & -0.2428 & 0.1495 & $1975-2004$ & 30 & No & journal article \\
\hline Ganau (2017) & 7 & -0.0610 & 0.0258 & 1981-2001 & 50 & No & journal article \\
\hline Gasiorowski (2000) & 3 & -0.0768 & 0.0241 & $1968-1991$ & 49 & Yes & journal article \\
\hline Gerring et al. (2005) & 25 & 0.0738 & 0.0629 & $1965-2000$ & 187 & Yes & journal article \\
\hline Gerring et al. (2013) & 32 & 0.0120 & 0.0165 & $1965-2005$ & 198 & No & unpubllished \\
\hline Ghosh et al. (2013) & 12 & -0.0009 & 0.1103 & $1960-2009$ & 15 & Yes & working paper \\
\hline Glaeser et al. (2004) & 12 & 0.1140 & 0.1356 & $1990-2000$ & 102 & Yes & journal article \\
\hline Goldsmith (1995) & 2 & 0.3493 & 0.0863 & 1988-1993 & 59 & No & journal article \\
\hline Gounder (2002) & 5 & 0.3085 & 0.0981 & 1968-1996 & 1 & No & journal article \\
\hline Green (2018) & 6 & 0.1230 & 0.0502 & $1961-2014$ & 45 & No & journal article \\
\hline Grier \& Tullock (1989) & 6 & 0.1503 & 0.1199 & 1961-1980 & 43 & No & journal article \\
\hline Gründler \& Krieger (2016) & 38 & 0.0877 & 0.1094 & 1981-2011 & 164 & Yes & journal article \\
\hline Gründler \& Krieger (2018) & 57 & 0.0287 & 0.0107 & $1960-2014$ & 170 & Yes & working paper \\
\hline Gupta (1988) & 2 & 0.1996 & 0.1172 & $1950-1977$ & 28 & No & journal article \\
\hline Gupta et al. (1998) & 1 & 0.0590 & NA & $1965-1986$ & 120 & Yes & journal article \\
\hline Gwartney et al. (1999) & 3 & -0.1870 & 0.1706 & 1980-1995 & 82 & Yes & journal article \\
\hline Haggard \& Tiede (2011) & 11 & -0.0083 & 0.0446 & $1985-2004$ & 98 & Yes & journal article \\
\hline Heckelman \& Wilson (2019) & 4 & 0.0844 & 0.0642 & $1975-2014$ & 132 & Yes & journal article \\
\hline Heckelman (2010) & 6 & 0.6557 & 0.5178 & $2000-2004$ & 25 & No & journal article \\
\hline Helliwell (1994a) & 3 & -1.0227 & 0.6046 & $1960-1985$ & 9 & No & working paper \\
\hline Helliwell (1994b) & 3 & -0.0446 & 0.0960 & $1960-1985$ & 90 & Yes & journal article \\
\hline Henisz (2000) & 7 & 0.1760 & 0.0869 & $1965-1990$ & 84 & Yes & journal article \\
\hline Heshmati \& Kim (2017) & 6 & 0.0518 & 0.0155 & $1980-2014$ & 144 & No & working paper \\
\hline Iqbal et al. (2012) & 4 & 0.3334 & 0.0483 & $1972-2010$ & 1 & Yes & journal article \\
\hline Jacob \& Osang (2018) & 71 & -0.0205 & 0.0466 & $1961-2010$ & 169 & No & journal article \\
\hline Jalles (2010) & 12 & 0.1103 & 0.0671 & $1975-2005$ & 86 & Yes & journal article \\
\hline Jamali et al. (2007) & 2 & 0.1192 & 0.0568 & 1990-1999 & 92 & Yes & journal article \\
\hline Jaunky (2013) & 1 & 0.0214 & NA & $1980-2005$ & 28 & No & journal article \\
\hline Jetter (2014) & 11 & 0.0219 & 0.0375 & $1961-2010$ & 90 & No & journal article \\
\hline Kagochi et al. (2007) & 3 & 0.3005 & 0.0139 & $1970-2000$ & 1 & No & journal article \\
\hline Kang et al. (2013) & 3 & -0.1737 & 0.0695 & $1996-2010$ & 27 & No & unpubllished \\
\hline Ken Farr et al. (1998) & 2 & 0.0339 & 0.2132 & $1976-1990$ & 78 & No & journal article \\
\hline Khanna (2017) & 6 & 0.0591 & 0.0287 & $1984-2005$ & 19 & Yes & journal article \\
\hline Kim \& Lee (2016) & 20 & 0.0284 & 0.0864 & $1976-2001$ & 154 & Yes & journal article \\
\hline Knack \& Keefer (1995) & 4 & 0.0515 & 0.0582 & 1974-1989 & 97 & No & journal article \\
\hline Knutsen (2013) & 45 & 0.1138 & 0.0708 & $1990-2004$ & 153 & No & journal article \\
\hline Knutsen et al. (2016) & 6 & 0.0337 & 0.0168 & $1960-2014$ & 149 & No & unpubllished \\
\hline Korhonen (2004) & 15 & 0.1303 & 0.1502 & $1970-2001$ & 106 & Yes & working paper \\
\hline Kormendi \& Meguire (1985) & 2 & 0.1669 & 0.1443 & $1950-1977$ & 47 & No & journal article \\
\hline Krieckhaus (2004) & 57 & -0.0407 & 0.2323 & 1990-1999 & 112 & Yes & journal article \\
\hline Krieckhaus (2006) & 55 & 0.0160 & 0.6179 & $1980-2000$ & 85 & Yes & journal article \\
\hline Kurzman et al. (2002) & 4 & -0.0700 & 0.0267 & $1951-1980$ & 107 & Yes & journal article \\
\hline Landau (1986) & 20 & -0.1244 & 0.0556 & $1960-1980$ & 65 & Yes & journal article \\
\hline
\end{tabular}




\begin{tabular}{|c|c|c|c|c|c|c|c|}
\hline Study & Coefficients & Mean Z & SD Z & Period & Countries & Includes HC & Publication type \\
\hline Leblang (1996) & 3 & 0.1169 & 0.0287 & $1960-1990$ & 50 & Yes & journal article \\
\hline Leblang (1997) & 9 & 0.1694 & 0.0443 & 1970-1989 & 92 & Yes & journal article \\
\hline Leschke (2000) & 2 & 0.2610 & 0.4955 & 1997-1997 & 80 & No & journal article \\
\hline Levine \& Renelt (1992) & 3 & 0.0282 & 0.1863 & $1960-1989$ & 86 & Yes & journal article \\
\hline Li \& Zou (1998) & 10 & -0.1310 & 0.2092 & 1960-1994 & 46 & Yes & journal article \\
\hline Lopes \& de Jesus (2015) & 6 & 0.1297 & 0.1679 & $1990-2010$ & 77 & Yes & journal article \\
\hline Lundberg \& Squire (2003) & 1 & -0.4103 & NA & 1960-1992 & 38 & Yes & journal article \\
\hline Ma \& Ouyang (2016) & 3 & 0.0323 & 0.0865 & $1960-2010$ & 48 & Yes & journal article \\
\hline Madsen et al. (2015) & 1 & 0.0942 & NA & $1950-2000$ & 141 & No & journal article \\
\hline Malikane \& Chitambara (2017) & 4 & 0.4049 & 0.1177 & 1989-2014 & 8 & Yes & journal article \\
\hline Marsh (1988) & 6 & 0.0000 & 0.1631 & 1970-1984 & 47 & No & journal article \\
\hline Masaki \& Van de Walle (2014) & 10 & 0.0546 & 0.0233 & $1982-2012$ & 43 & No & working paper \\
\hline Mazurek (2017) & 1 & -0.7993 & NA & 2005-2015 & 32 & Yes & journal article \\
\hline Mbaku \& Kimenyi (1997) & 10 & 0.4915 & 0.2005 & 1950-1985 & 46 & No & journal article \\
\hline Mbaku (1994) & 12 & 0.0597 & 0.1862 & 1970-1991 & 117 & No & journal article \\
\hline Mehanna (2006) & 2 & 0.1412 & 0.0067 & 1982-1999 & 80 & Yes & journal article \\
\hline Miguel et al. (2004) & 1 & 0.0054 & NA & 1981-1999 & 41 & No & journal article \\
\hline Minier (1998) & 4 & 0.1661 & 0.1248 & 1970-1989 & 96 & Yes & journal article \\
\hline Minier (2003) & 4 & 0.1731 & 0.1497 & 1970-1990 & 73 & Yes & journal article \\
\hline Mira \& Hammadache (2017) & 12 & 0.0104 & 0.1136 & $1996-2001$ & 45 & No & working paper \\
\hline Mo (2000) & 16 & -0.2319 & 0.0900 & $1970-1985$ & 83 & Yes & journal article \\
\hline Mo (2001) & 9 & -0.2773 & 0.0969 & 1970-1985 & 46 & Yes & journal article \\
\hline Mo (2015) & 14 & -0.0271 & 0.1812 & 1970-1985 & 105 & Yes & journal article \\
\hline Mobarak (2005) & 13 & -0.0199 & 0.0933 & $1960-1990$ & 77 & Yes & journal article \\
\hline Murtin \& Wacziarg (2014) & 3 & -0.0043 & 0.1142 & $1960-2000$ & 69 & No & journal article \\
\hline Nelson \& Singh (1998) & 6 & 0.1529 & 0.0128 & 1970-1989 & 67 & No & journal article \\
\hline Oliva \& Rivera Batiz (2002) & 11 & 0.1851 & 0.0587 & 1970-1994 & 120 & Yes & journal article \\
\hline Parada \& Garçia (2008) & 10 & 0.1065 & 0.1507 & 1984-1999 & 17 & Yes & working paper \\
\hline Perotti (1996) & 2 & -0.1070 & 0.0299 & 1960-1985 & 67 & Yes & journal article \\
\hline Persson \& Tabellini (1992) & 3 & -0.1105 & 0.2709 & 1960-1985 & 50 & Yes & journal article \\
\hline Persson \& Tabellini (1994) & 1 & -0.3991 & NA & 1960-1985 & 49 & Yes & journal article \\
\hline Pettersson (2004) & 44 & -0.0681 & 0.0415 & $1982-2000$ & 129 & Yes & working paper \\
\hline Piatek (2016) & 1 & -0.9284 & NA & $2007-2010$ & 25 & No & journal article \\
\hline Pinho \& Madaleno (2009) & 15 & 0.0403 & 0.0263 & $1960-2000$ & 170 & Yes & unpubllished \\
\hline Pitlik (2002) & 4 & 0.1144 & 0.0287 & 1975-1995 & 73 & Yes & journal article \\
\hline Plümper \& Martin (2003) & 9 & 0.3313 & 0.1323 & 1975-1997 & 83 & Yes & journal article \\
\hline Polterovich \& Popov (2007) & 2 & -0.0336 & 0.1914 & 1975-1999 & 45 & No & working paper \\
\hline Pourgerami \& Assane (1992) & 8 & 0.4017 & 0.2595 & 1950-1977 & 47 & No & journal article \\
\hline Pourgerami (1988) & 3 & 0.4055 & 0.2351 & 1965-1984 & 92 & No & journal article \\
\hline Pourgerami (1992) & 7 & 0.0861 & 0.0872 & 1958-1986 & 104 & Yes & journal article \\
\hline Quinn \& Woolley (2001) & 2 & 0.0736 & 0.1092 & 1974-1989 & 92 & Yes & journal article \\
\hline Qureshi \& Ahmed (2012) & 5 & 0.0338 & 0.1497 & $1987-2002$ & 73 & Yes & working paper \\
\hline Rivera-Batiz (2002) & 2 & 0.1794 & 0.2207 & 1960-1990 & 59 & Yes & journal article \\
\hline Rodrik (1997) & 1 & 0.0016 & NA & 1970-1989 & 90 & No & working paper \\
\hline Rodrik (1999) & 2 & 0.2225 & 0.0108 & 1960-1989 & 104 & No & journal article \\
\hline Rossignoli (2014) & 6 & 0.0113 & 0.0197 & 1961-2010 & 169 & No & book \\
\hline Sakyi \& Adams (2012) & 4 & -0.4147 & 0.0823 & $1960-2008$ & 1 & No & journal article \\
\hline Salahodjaev (2015) & 12 & 0.2389 & 0.0983 & 1990-2013 & 120 & Yes & journal article \\
\hline Sala-i-Martin (1997) & 2 & 0.2546 & 0.0000 & 1960-1992 & 133 & No & journal article \\
\hline Scully (1988) & 4 & 0.1222 & 0.2177 & $1960-1980$ & 115 & No & journal article \\
\hline Siermann (1998) & 42 & 0.0810 & 0.0864 & 1973-1992 & 110 & No & book \\
\hline Svensson (1999) & 16 & -0.0543 & 0.1492 & 1970-1989 & 68 & Yes & journal article \\
\hline Sylwester (2015) & 16 & 0.0260 & 0.0077 & 1950-2007 & 180 & Yes & journal article \\
\hline Tang \& Tang (2018) & 77 & 0.0446 & 0.0298 & $1970-2010$ & 112 & No & journal article \\
\hline Vorhies \& Glahe (1988) & 1 & 0.5340 & NA & 1986-1986 & 150 & No & journal article \\
\hline Weede (1983) & 10 & -0.3388 & 0.1943 & 1960-1979 & 94 & Yes & journal article \\
\hline Weede (1984) & 11 & -0.3527 & 0.1778 & $1960-1979$ & 75 & Yes & journal article \\
\hline Weede (1993) & 6 & 0.0329 & 0.0737 & 1987-1987 & 96 & Yes & journal article \\
\hline Weede (1996) & 5 & -0.0063 & 0.1594 & 1980-1987 & 93 & Yes & journal article \\
\hline Weede (1997) & 9 & -0.1860 & 0.0677 & $1960-1985$ & 48 & Yes & journal article \\
\hline Williams (2017) & 29 & 0.1014 & 0.0780 & $1982-2011$ & 78 & No & journal article \\
\hline Williams (2018) & 6 & 0.3292 & 0.6027 & $1970-2014$ & 81 & No & journal article \\
\hline
\end{tabular}




\begin{tabular}{|c|c|c|c|c|c|c|c|}
\hline Study & Coefficients & Mean Z & $\mathrm{SD} \mathrm{Z}$ & Period & Countries & Includes HC & Publication type \\
\hline Wu \& Davis (1999) & 6 & 0.0093 & 0.0141 & $1975-1990$ & 92 & No & journal article \\
\hline Wu (2012) & 18 & 0.0315 & 0.0539 & $1960-2001$ & 111 & No & journal article \\
\hline Xi (2017) & 2 & 0.0111 & 0.0059 & $1950-2010$ & 167 & No & journal article \\
\hline Yanıkkaya \& Turan (2019) & 9 & -0.1052 & 0.0566 & 1960-2009 & 122 & Yes & journal article \\
\hline Yanovskiy \& Ginker (2017) & 5 & 0.0365 & 0.0067 & 1970-2012 & 124 & Yes & journal article \\
\hline Zakaria \& Fida (2009) & 22 & -0.4268 & 0.1558 & $1947-2006$ & 1 & Yes & journal article \\
\hline Zallé (2018) & 2 & 0.0326 & 0.2471 & $2000-2015$ & 29 & Yes & journal article \\
\hline Zaouali (2014) & 4 & 0.1217 & 0.1066 & $2000-2011$ & 40 & Yes & working paper \\
\hline Zouhaier \& Karim (2012) & 2 & -0.1647 & 0.0861 & 2000-2009 & 11 & No & journal article \\
\hline
\end{tabular}

Notes: Coefficients indicates the number of effect sizes included in the manuscript. Mean $Z$ and $S D Z$ are, respectively, the mean value of the Fisher's $Z$ and its standard deviation. $S D Z$ is equal to NA if only one coefficient is available in the manuscript. Period describes the longest time-span investigated in the manuscript and Countries the largest sample of countries analyzed. Includes $H C$ indicates whether in at least one of the specifications collected from the manuscript there is a proxy of human capital. Publication type is: "journal article" if the manuscript venue is among those included in the IDEAS/RePEc H-Index journals list; "working paper" if the manuscript venue is among those included in the IDEAS/RePEc H-Index working papers list; "book" if the manuscript is a book or a contribution in a book; "unpublished" if neither "journal article" nor "working paper" nor "book" apply. 
Appendix A.1. The meta-sample: references

Meta-sample

Abdelkader, H. E. (2015). Political instability, uncertainty, democracy, and economic growth in egypt. In Economic Research Forum Working Papers 953.

Abida, Z., Sghaier, I. M., \& Zghidi, N. (2015). Financial development and economic growth: Evidence from north african countries. Economic Alternatives, 7, 17-33.

Acemoglu, D., Johnson, S., Robinson, J. A., \& Yared, P. (2008). Income and democracy. American Economic Review, 98, 808-842.

Acemoglu, D., Naidu, S., Restrepo, P., \& Robinson, J. A. (2019). Democracy does cause growth. Journal of Political Economy, 127, 47-100.

Adams, S., \& Klobodu, E. K. (2016). Remittances, regime durability and economic growth in sub-saharan africa (ssa). Economic Analysis and Policy, 50, 1-8.

Adom, P. K. (2016). The DDT Effect: The case of Economic Growth. 75022.

Aghion, P., Alesina, A. F., \& Trebbi, F. (2007). Democracy, technology, and growth. NBER Working Paper, 1318.

Ahmad, M., \& Hall, S. G. (2017). Economic growth and convergence: Do institutional proximity and spillovers matter? Journal of Policy Modeling, 39, 1065-1085.

Aisen, A., \& Veiga, F. J. (2013). How does political instability affect economic growth? European Journal of Political Economy, 29, 151-167.

Albornoz-Crespo, F., \& Dutta, J. (2007). Political regimes and economic growth in latin america. University of Birmingham, Department of Economics discussion paper, (pp. 07-06).

Alesina, A., Özler, S., Roubini, N., \& Swagel, P. (1996). Political instability and economic growth. Journal of Economic growth, 1, 189-211.

Alesina, A., \& Rodrik, D. (1994). Distributive politics and economic growth. The Quarterly Journal of Economics, 109, 465-490.

Ali, A. M. (1997). Economic freedom, democracy and growth. Journal of Private Enterprise, 13, 1-20.

Ali, A. M. (2003). Institutional differences as sources of growth differences. Atlantic Economic Journal, 31, 348-362.

Ali, A. M., \& Crain, W. M. (2001a). Institutional distortions, economics freedom, and growth. Cato Journal, 21, 415. 
Ali, A. M., \& Crain, W. M. (2001b). Political regimes, economic freedom, institutions and growth. Journal of Public Finance and Public Choice, 19, 3-22.

Almeida, H., \& Ferreira, D. (2002). Democracy and the variability of economic performance. Economics \& Politics, 14, 225-257.

Alpalhão, H. (2019). Democracy as a curve.

Antič, M. (2004). Democracy versus dictatorship: The influence of political regime on gdp per capita growth. Ekonomski pregled, 55, 773-803.

Arfaoui, L., Ziadi, A., \& Manai, S. (2016). The relationship between democracy and economic growth in tunisia: An application of autoregressive distributed lag model. International Journal of Social Science Research, 4, 137-150.

Assane, D., \& Pourgerami, A. (1994). Monetary cooperation and economic growth in africa: Comparative evidence from the cfazone countries. The Journal of Development Studies, 30, 423-442.

Assiotis, A., \& Sylwester, K. (2014). Do the effects of corruption upon growth differ between democracies and autocracies? Review of Development Economics, 18, $581-594$.

Assiotis, A., \& Sylwester, K. (2015). Does law and order attenuate the benefits of democracy on economic growth? Economica, 82, 644-670.

Aziz, N., \& Ahmad, A. H. (2018). Institutions and Economic Growth: Does Income Level Matter?. Technical Report University Library of Munich, Germany.

Baklouti, N., \& Boujelbene, Y. (2015). Exploring the relationship between democracy, corruption and economic growth in mena countries. Acta Universitatis Danubius. Rconomica, 11, 3 .

Baklouti, N., \& Boujelbene, Y. (2018). The nexus between democracy and economic growth: evidence from dynamic simultaneous-equations models. Journal of the Knowledge Economy, 9, 980-998.

Barro, R. J. (1996a). Democracy and growth. Journal of economic growth, 1, 1-27.

Barro, R. J. (1996b). Determinants of economic growth: A cross-country empirical study. National Bureau of Economic Research, w5698.

Barro, R. J. (2000). Inequality and growth in a panel of countries. Journal of economic growth, 5, 5-32.

Barro, R. J., \& Lee, J. W. (1993). Losers and winners in economic growth. National Bureau of Economic Research, w4341. 
Bataka, H. (2019). De jure, de facto globalization and economic growth in sub-saharan africa. Journal of Economic Integration, 34, 133-158.

Baum, M. A., \& Lake, D. A. (2003). The political economy of growth: Democracy and human capital. American Journal of Political Science, 47, 333-347.

Bhalla, S. S. (1997). Freedom and economic growth: a virtuous cycle? In Democracy's Victory and Crisis (pp. 93-195).

Bleaney, M., \& Nishiyama, A. (2002). Explaining growth: a contest between models. Journal of Economic Growth, 7, 43-56.

Bluedorn, J. C. (2001). Can democracy help? growth and ethnic divisions. Economics Letters, 70, 121-126.

Boko, S. H. (2002). Economic reform, democracy, and economic growth in africa: An institutional approach. International Advances in Economic Research, 8, 264-264.

Bornscheir, V., \& Scholtz, H. (2002). Democracy Economic Growth and Technoeconomic Change-Empirical Evidence for Neglected Indirect Effects.

Bougharriou, N., Benayed, W., \& Gabsi, F. B. (2019). The democracy and economic growth nexus: do fdi and government spending matter? evidence from the arab world. Economics: The Open-Access, Open-Assessment E-Journal, 13, 1-29.

Brueckner, M., Hansl, B. et al. (2018). Drivers of Growth in the Philippines. Technical Report Centre for Economic Policy Research, Research School of Economics.

Butkiewicz, J. L., \& Yanikkaya, H. (2006). Institutional quality and economic growth: Maintenance of the rule of law or democratic institutions, or both? Economic Modelling, 23, 648-661.

Butkiewicz, J. L., \& Yanikkaya, H. (2007). Time-consistent polities and growth in developing countries: An empirical analysis. Review of World Economics, 143, 306-323.

Cavallo, A. F., \& Cavallo, E. A. (2010). Are crises good for long-term growth? the role of political institutions. Journal of Macroeconomics, 32, 838-857.

Chan, S.-G., Ramly, Z., \& Karim, M. Z. A. (2017). Government spending efficiency on economic growth: Roles of value-added tax. Global Economic Review, 46, 162-188.

Chatterji, M. (1998). Tertiary education and economic growth. Regional Studies, 32, 349-354.

Chen, B. L. (2003). An inverted-u relationship between inequality and long-run growth. Economics Letters, 78, 205-212. 
Chen, S., Chernozhukov, V., \& Fernández-Val, I. (2019). Mastering panel'metrics: Causal impact of democracy on growth. arXiv preprint arXiv:1901.03821, .

Chousa, J. P., Khan, H. A., Melikyan, D. N., \& Tamazian, A. (2006). Democracy, finance and development. CIRJE-FCIRJE, Faculty of Economics, University of Tokyo, 458 .

Collier, P. (1999). The political economy of ethnicity. In B. Pleskovic, \& J. E. Stiglitz (Eds.), Annual Bank Conference on Development Economics.

Collier, P. (2000). Ethnicity, politics and economic performance. Economics 85 Politics, 12, 225-245.

Combes, J.-L., Kinda, T., Ouedraogo, R., \& Plane, P. (2019). Financial flows and economic growth in developing countries. Economic Modelling, Forthcoming.

Comeau, L. (2003). Democracy and growth: A relationship revisited. Eastern Economic Journal, 29, 1-21.

Corujo, S. A., \& Simões, M. C. (2012). Democracy and growth: Evidence for portugal (1960 2001). Transition Studies Review, 18, 512-528.

De la Croix, D., \& Delavallade, C. (2011). Democracy, rule of law, corruption incentives, and growth. Journal of Public Economic Theory, 13, 155-187.

Dasgupta, S., Bhattacharya, D., \& Neethi, D. J. (2013). Does democracy impact economic growth? exploring the case of bangladesh - a cointegrated var approach. MPRA Paper, University Library of Munich, Germany, 56621.

Dawson, J. W. (1998). Institutions, investment, and growth: New crosscountry and panel data evidence. Economic inquiry, 36, 603-619.

De Haan, J., \& Siermann, C. L. (1995). A sensitivity analysis of the impact of democracy on economic growth. Empirical Economics, 20, 197-215.

De Haan, J., \& Siermann, C. L. (1996a). New evidence on the relationship between democracy and economic growth. Public Choice, 86, 175-198.

De Haan, J., \& Siermann, C. L. (1996b). Political instability, freedom, and economic growth: Some further evidence. Economic Development and Cultural Change, (pp. 339-350).

De Luca, G., Litina, A., \& Sekeris, P. G. (2015). Growth-friendly dictatorships. Journal of Comparative Economics, 43, 98-111.

Deana, G., \& Gamba, A. (2008). Democracy, openness and jumps in growth. KITeS, Centre for Knowledge, Internationalization and Technology Studies, Università Bocconi, Milano, Italy, 221. 
Decker, J. H., \& Lim, J. J. (2008). What fundamentally drives growth? revisiting the institutions and economic performance debate. Journal of International Development, 20, 698.

Dias, J., \& Tebaldi, E. (2012). Institutions, human capital, and growth: The institutional mechanism. Structural Change and Economic Dynamics, 23, 300-312.

Diebolt, C., Mishra, T., Ouattara, B., \& Parhi, M. (2013). Democracy and economic growth in an interdependent world. Review of International Economics, 21, 733749 .

Amir-ud Din, R., \& Khan, R. E. A. (2017). Democracy, income inequality and economic growth nexus: The case of pakistan. Pakistan Journal of Commerce and Social Sciences (PJCSS), 11, 206-221.

Doucouliagos, C., \& Ulubasoglu, M. A. (2006). Economic freedom and economic growth: Does specification make a difference? European Journal of Political Economy, 22, 60-81.

Drury, A. C., Krieckhaus, J., \& Lusztig, M. (2006). Corruption, democracy, and economic growth. International Political Science Review, 27, 121-136.

Durham, J. B. (1999). Economic growth and political regimes. Journal of Economic Growth, 4, 81-111.

Emara, N., \& Jhonsa, E. (2014). Governance and economic growth: The case of middle eastern and north african countries. MPRA Paper, University Library of Munich, Germany, 68683.

Fedderke, J., \& Klitgaard, R. (1998). Economic growth and social indicators: an exploratory analysis. Economic development and cultural change, 46, 455-489.

Feng, Y. (1995). Regime, polity, and economic growth: the latin American experience. Growth and Change, 26, 77-104.

Feng, Y. (1996). Democracy and growth: The sub-saharan african case, 19601992. The Review of Black Political Economy, 25, 95-126.

Feng, Y. (1997). Democracy, political stability and economic growth. British Journal of Political Science, 27, 03.

Fidrmuc, J. (2003). Economic reform, democracy and growth during post-communist transition. European journal of political economy, 19, 583-604.

Flachaire, E., Garcia-Peñalosa, C., \& Konte, M. (2014). Political versus economic institutions in the growth process. Journal of Comparative Economics, 42, 212229 . 
Fosu, A. K. (2008). Democracy and growth in africa: Implications of increasing electoral competitiveness. Economics Letters, 100, 442-444.

Ganau, R. (2017). Institutions and economic growth in africa: a spatial econometric approach. Economia Politica, 34, 425-444.

Gasiorowski, M. J. (2000). Democracy and macroeconomic performance in underdeveloped countries an empirical analysis. Comparative Political Studies, 33, 319-349.

Gerring, J., Bond, P., Barndt, W. T., \& Moreno, C. (2005). Democracy and economic growth: A historical perspective. World Politics, 5\%, 03.

Gerring, J., Skaaning, S. E., Maguire, M., \& Tzelgov, E. (2013). Democracy and growth: A lexical approach.

Ghosh, S., Gregoriou, A., \& Mitra, A. (2013). On the role of democracy in the ethnicity-growth relationship: Theory and evidence (no. 13-02). Centre for Economic Development and Institutions (CEDI), Brunel University, .

Glaeser, E. L., La Porta, R., Lopez-de SIlanes, F., F., S., \& Shleifer, A. (2004). Do institutions cause growth? Journal of economic Growth, 9, 271-303.

Goldsmith, A. A. (1995). Democracy, property rights and economic growth. The Journal of Development Studies, 32, 157-174.

Gounder, R. (2002). Political and economic freedom, fiscal policy, and growth nexus: some empirical results for fiji. Contemporary Economic Policy, 20, 234-245.

Green, A. (2018). Democracy and institutions in postcolonial africa. Journal of Institutional Economics, 14, 207-231.

Grier, K. B., \& Tullock, G. (1989). An empirical analysis of cross-national economic growth, 19511980. Journal of Monetary Economics, 24, 259-276.

Gründler, K., \& Krieger, T. (2016). Democracy and growth: Evidence from a machine learning indicator. European Journal of Political Economy, 45, 85-107.

Gründler, K., \& Krieger, T. (2018). Machine Learning Indices, Political Institutions, and Economic Development. Technical Report CESifo Group Munich. URL: https://www . econstor.eu/bitstream/10419/176949/1/cesifo1_wp6930.pdf.

Gupta, D. K., Madhavan, M. C., \& Blee, A. (1998). Democracy, economic growth and political instability: an integrated perspective. The Journal of Socio-Economics, 27, 587-611.

Gupta, K. L. (1988). Macroeconomic determinants of growth: some implications of disaggregation. Applied Economics, 20, 843-852. 
Gwartney, J. D., Lawson, R. A., \& Holcombe, R. G. (1999). Economic freedom and the environment for economic growth. Journal of Institutional and Theoretical Economics (JITE)/Zeitschrift für die gesamte Staatswissenschaft, (pp. 643-663).

Haggard, S., \& Tiede, L. (2011). The rule of law and economic growth: where are we? World Development, 39, 673-685.

Heckelman, J. C. (2010). The connection between democratic freedoms and growth in transition economies. Applied Economics Quarterly (formerly: Konjunkturpolitik), $56,121-146$.

Heckelman, J. C., \& Wilson, B. (2019). The growth-maximizing level of regulation: Evidence from a panel of international data. European Journal of Political Economy, 59, 354-368.

Helliwell, J. F. (1994a). Empirical linkages between democracy and economic growth. British Journal of Political Science, 24, 02.

Helliwell, J. F. (1994b). International growth linkages: evidence from asia and the oecd. In Macroeconomic Linkage: Savings, Exchange Rates, and Capital Flows, NBER-EASE Volume 3 (pp. 7-29). University of Chicago Press.

Henisz, W. J. (2000). The institutional environment for economic growth. Economics \& Politics, 12, 1-31.

Heshmati, A., \& Kim, N. S. (2017). The relationship between economic growth and democracy: Alternative representations of technological change (no. 10880). Institute for the Study of Labor (IZA), 10880.

Iqbal, N., Din, M. U., \& Ghani, E. (2012). Fiscal decentralisation and economic growth: role of democratic institutions. The Pakistan Development Review, (pp. 173-195).

Jacob, J. A., \& Osang, T. (2018). Democracy and growth: A dynamic panel data study. The Singapore Economic Review, (pp. 1-40).

Jalles, J. T. (2010). Does democracy foster or hinder growth? extreme-type political regimes in a large panel. Economics Bulletin, 30, 1359-1372.

Jamali, K., Wandschneider, K., \& Wunnava, P. V. (2007). The effect of political regimes and technology on economic growth. Applied Economics, 39, 1425-1432.

Jaunky, V. C. (2013). Democracy and economic growth in sub-saharan africa: a panel data approach. Empirical Economics, 45, 987-1008.

Jetter, M. (2014). Volatility and growth: Governments are key. European Journal of Political Economy, 36, 71-88. 
Kagochi, J., Tackie, N. O., \& Thompson, H. (2007). An analysis of the impact of freedoms on economic growth. Journal of African Development, 9, 13-29.

Kang, B. K., Chu, G. Y., \& Lee, S. J. (2013). Democracy and economic growth in post-communist transition countries.

Ken Farr, W., Lord, R. A., \& Wolfenbarger, J. L. (1998). Economic freedom, political freedom, and economic well-being: A causality analysis. Cato Journal, 18, 247.

Khanna, A. A. (2017). Revisiting the oil curse: Does ownership matter? World Development, 99, 214-229.

Kim, J., \& Lee, N. Y. (2016). The effect of high-skilled emigration, foreign direct investment, and policy on the growth rate of source countries: A panel analysis. East Asian Economic Review, 20, 229-275.

Knack, S., \& Keefer, P. (1995). Institutions and economic performance: cross country tests using alternative institutional measures. Economics \& Politics, 7, 207-227.

Knutsen, C. H. (2013). Democracy, state capacity, and economic growth. World Development, 43, 1-18.

Knutsen, C. H., Gerring, J., \& Skaaning, S. (2016). Local democracy and economic growth. V-Dem Working Paper, 39.

Korhonen, I. (2004). Does democracy cure a resource curse? Bank of Finland, Institute for Economies in Transition, 18/2004.

Kormendi, R. C., \& Meguire, P. G. (1985). Macroeconomic determinants of growth: cross-country evidence. Journal of Monetary economics, 16, 141-163.

Krieckhaus, J. (2004). The regime debate revisted: A sensitivity analysis of democracy's economic effect. ritish Journal of Political Science, 34, 04.

Krieckhaus, J. (2006). Democracy and economic growth: how regional context influences regime effects. British Journal of Political Science, 36, 02.

Kurzman, C., Werum, R., \& Burkhart, R. E. (2002). Democracy s effect on economic growth: a pooled time-series analysis, 19511980. Studies in Comparative International Development, 37, 3-33.

Landau, D. (1986). Government and economic growth in the less developed countries: an empirical study for 1960-1980. Economic Development and Cultural Change, 35, $35-75$.

Leblang, D. A. (1996). Property rights, democracy and economic growth. Political Research Quarterly, 49, 5-26. 
Leblang, D. A. (1997). Political democracy and economic growth: pooled crosssectional and time-series evidence. British Journal of Political Science, 27, 03.

Leschke, M. (2000). Constitutional choice and prosperity: A factor analysis. Constitutional Political Economy, 11, 265-279.

Levine, R., \& Renelt, D. (1992). A sensitivity analysis of cross-country growth regressions. The American Economic Review, (pp. 942-963).

Li, H., \& Zou, H. F. (1998). Income inequality is not harmful for growth: theory and evidence. Review of Development Economics, 2, 318-334.

Lopes, T. H. C. R., \& de Jesus, C. S. (2015). Financial liberalization and economic growth: The (ir) relevance of the democracy context. Journal of Economic Studies, 42, 207-223.

Lundberg, M., \& Squire, L. (2003). The simultaneous evolution of growth and inequality. The Economic Journal, 113, 326-344.

Ma, T. C., \& Ouyang, L. (2016). Democracy and growth: A perspective from democratic experience. Economic Inquiry, 54, 1790-1804.

Madsen, J. B., Raschky, P. A., \& Skali, A. (2015). Does democracy drive income in the world, 1500 2000? European Economic Review, 78, 175-195.

Malikane, C., \& Chitambara, P. (2017). Foreign direct investment, democracy and economic growth in southern africa. African Development Review, 29, 92-102.

Marsh, R. M. (1988). Sociological explanations of economic growth. Studies in Comparative International Development, 23, 41-76.

Masaki, T., \& Van de Walle, N. (2014). The impact of democracy on economic growth in sub-saharan africa, 1982-2012. WIDER Working Paper, $5 \%$.

Mazurek, J. (2017). On determinants of the economic growth of european countries during 20052015. Comparative Economic Research, 20, 21-33.

Mbaku, J. M. (1994). The political economy of development: An empirical analysis of the effects of the institutional framework on economic development. Studies in Comparative International Development, 29, 3-21.

Mbaku, J. M., \& Kimenyi, M. S. (1997). Macroeconomic determinants of growth: Further evidence on the role of political freedom. Journal of Economic Development, 22, 119-132.

Mehanna, R. A. (2006). Does democracy really promote development? Global Business and Economics Review, 8, 328-337. 
Miguel, E., Satyanath, S., \& Sergenti, E. (2004). Economic shocks and civil conflict: An instrumental variables approach. Journal of Political Economy, 112, 725-753.

Minier, J. A. (1998). Democracy and growth: Alternative approaches. Journal of economic growth, 3, 241-266.

Minier, J. A. (2003). Democrats, dictators, and demonstrators. Economic Inquiry, 41, 224-233.

Mira, R., \& Hammadache, A. (2017). Relationship between good governance and economic growth - a contribution to the institutional debate about state failure in developing countries. Centre d'Economie de l'Universitè de Paris Nord, 12.

Mo, P. H. (2000). Income inequality and economic growth. Kyklos, 53, 293-315.

Mo, P. H. (2001). Corruption and economic growth. Journal of Comparative Economics, 29, 66-79.

Mo, P. H. (2015). Democracy and economic growth: Optimal level and transmission channels. Frontiers of Economics in China, 10, 85.

Mobarak, A. M. (2005). Democracy, volatility, and economic development. Review of Economics and Statistics, 87, 348-361.

Murtin, F., \& Wacziarg, R. (2014). The democratic transition. Journal of Economic Growth, 19, 141-181.

Nelson, M. A., \& Singh, R. D. (1998). Democracy, economic freedom, fiscal policy, and growth in ldcs: A fresh look. Economic Development and Cultural Change, 46, 677-696.

Oliva, M. A., \& Rivera Batiz, L. A. (2002). Political institutions, capital flows, and developing country growth: An empirical investigation. Review of Development Economics, 6, 248-262.

Parada, J., \& Garçia, A. (2008). Growth and institutions in latin america: A pooled and cross-time series analysis (1951-1999) - crecimiento e instituciones en america latina. Revista de Economia del Caribe, 1.

Perotti, R. (1996). Growth, income distribution, and democracy: What the data say. Journal of Economic Growth, 1, 149-187.

Persson, T., \& Tabellini, G. (1992). Growth, distribution and politics. European Economic Review, 36, 593-602.

Persson, T., \& Tabellini, G. (1994). Is inequality harmful for growth? The American Economic Review, (pp. 600-621). 
Pettersson, J. (2004). Stockholm University, Department of Economics volume 16.

Piatek, D. (2016). Institutions and economic growth in transition countries: new experiences and implications from financial crisis 20072010 (part 2). Ekonomia $i$ Prawo. Economics and Law, 15, 527-545.

Pinho, C., \& Madaleno, M. (2009). Political regimes and economic growth. Revista Enfoques: Ciencia Politica y Administracion Publica, 7, 11.

Pitlik, H. (2002). The path of liberalization and economic growth. Kyklos, 55, 57-80.

Plümper, T., \& Martin, C. W. (2003). Democracy, government spending, and economic growth: A political-economic explanation of the barro-effect. Public Choice, $117,27-50$.

Polterovich, V., \& Popov, V. (2007). Democratization, quality of institutions and economic growth. MPRA Paper, University Library of Munich, Germany, 19152.

Pourgerami, A. (1988). The political economy of development: A cross-national causality test of development-democracy-growth hypothesis. Public Choice, 58, $123-141$.

Pourgerami, A. (1992). Authoritarian versus nonauthoritarian approaches to economic development: Update and additional evidence. Public Choice, 74, 365-377.

Pourgerami, A., \& Assane, D. (1992). Macroeconomic determinants of growth: new measurement and evidence on the effect of political freedom. Applied Economics, 24, 129-136.

Quinn, D. P., \& Woolley, J. T. (2001). Democracy and national economic performance: the preference for stability. American Journal of Political Science, (pp. 634-657).

Qureshi, M. G., \& Ahmed, E. (2012). The inter-linkages between democracy and per capita gdp growth: A cross country analysis. Working Papers $\& 3$ Research Reports, 2012.

Rivera-Batiz, F. L. (2002). Democracy, governance, and economic growth: theory and evidence. Review of Development Economics, 6, 225-247.

Rodrik, D. (1997). Democracy and economic performance. Harvard University, December, 14, 707-38.

Rodrik, D. (1999). Where did all the growth go? external shocks, social conflict, and growth collapses. Journal of Economic Growth, 4, 385-412. 
Rossignoli, D. (2014). Institutions, democracy and economic growth. Facts, theories and beyond. Vita e Pensiero.

Sakyi, D., \& Adams, S. (2012). Democracy, government spending and economic growth: The case of ghana, 1960-2008. Margin: The Journal of Applied Economic Research, 6, 361-383.

Sala-i-Martin, X. (1997). I just ran two million regressions. The American Economic Review, 87, 178-183.

Salahodjaev, R. (2015). Democracy and economic growth: The role of intelligence in cross-country regressions. Intelligence, 50, 228-234.

Scully, G. W. (1988). The institutional framework and economic development. Journal of Political Economy, 96, 652-662.

Siermann, C. L. (1998). Politics, Institutions, and the Economic Performance of Nations. Cheltenham, UK: E. Elgar.

Svensson, J. (1999). Aid, growth and democracy. Economics \& Politics, 11, 275-297.

Sylwester, K. (2015). Does democracy increase growth more in new countries? Economics 8 Politics, 27, 266-289.

Tang, R., \& Tang, S. (2018). Democracy's unique advantage in promoting economic growth: Quantitative evidence for a new institutional theory. Kyklos, 71, 642-666.

Vorhies, F., \& Glahe, F. (1988). Political liberty and social development: An empirical investigation. Public Choice, 58, 45-71.

Weede, E. (1983). The impact of democracy on economic growth: Some evidence from cross-national analysis. Kyklos, 36, 21-39.

Weede, E. (1984). Political democracy, state strength and economic growth in ldcs: a cross-national analysis. Review of International Studies, 10, 297-312.

Weede, E. (1993). The impact of democracy or repressiveness on the quality of life, income distribution and economic growth rates. International Sociology, 8, 177195.

Weede, E. (1996). Political regime type and variation in economic growth rates. Constitutional Political Economy, 7, 167-176.

Weede, E. (1997). Income inequality, democracy and growth reconsidered. European Journal of Political Economy, 13, 751-764.

Williams, K. (2017). Does democracy dampen the effect of finance on economic growth? Empirical Economics, 52, 635-658. 
Williams, K. (2018). Do political institutions improve the diminishing effect of financial deepening on growth? evidence from developing countries. Journal of Economics and Business, 103, 13-24.

Wu, C. E. (2012). When is democracy better for economic performance and when is it not: The interaction between polity and structural factors. Studies in Comparative International Development, 47, 365-388.

Wu, W., \& Davis, O. A. (1999). The two freedoms in a growth model. Journal of Private Enterprise, 14, 115-143.

$\mathrm{Xi}, \mathrm{T}$. (2017). Inclusive institutions and economic growth: comparative perspective and policy implications for china. China Economic Journal, 10, 108-127.

Yanıkkaya, H., \& Turan, T. (2019). Polity stability, economic growth, and investment: A dynamic panel analysis. Peace Economics, Peace Science and Public Policy, 25.

Yanovskiy, M., \& Ginker, T. (2017). A proposal for a more objective measure of de facto constitutional constraints. Constitutional Political Economy, (pp. 1-10).

Zakaria, M., \& Fida, B. A. (2009). Democratic institutions and variability of economic growth in pakistan: some evidence from the time-series analysis. The Pakistan Development Review, (pp. 269-289).

Zallé, O. (2018). Natural resources and economic growth in africa: The role of institutional quality and human capital. Resources Policy, 62, 616-624.

Zaouali, A. (2014). Corruption's and democracy's effects on economic growth. MPRA Paper, University Library of Munich, Germany, 54535.

Zouhaier, H., \& Karim, K. M. (2012). Democracy, investment and economic growth. International Journal of Economics and Financial Issues, 2, 233. 


\section{Appendix B. Robustness checks}

Table B.1: Meta-analysis, linear specifications only

\begin{tabular}{|c|c|c|c|c|c|c|}
\hline & $\begin{array}{c}\text { RE ML } \\
\text { (s.e.) }\end{array}$ & $\begin{array}{c}\text { FE } \\
\text { (clustered s.e.) }\end{array}$ & $\begin{array}{c}\mathrm{RE} \\
\text { (clustered s.e.) }\end{array}$ & $\begin{array}{c}\text { Total Îे } \\
{[\text { Between Îे] }}\end{array}$ & ICC & $\begin{array}{c}\text { Studies } \\
{[\text { Effect sizes] }}\end{array}$ \\
\hline Democracy & $\begin{array}{r}0.0565^{* * *} \\
(0.0156)\end{array}$ & $\begin{array}{r}0.0317^{* * *} \\
(0.0049)\end{array}$ & $\begin{array}{r}0.0453^{* * *} \\
(0.0125)\end{array}$ & $\begin{array}{r}97.85 \% \\
{[95.15 \%]}\end{array}$ & 0.972 & $\begin{array}{r}151 \\
{[1364]}\end{array}$ \\
\hline Human capital & $\begin{array}{r}0.1480^{* * *} \\
(0.0173)\end{array}$ & $\begin{array}{r}0.0749^{* * * *} \\
(0.0165)\end{array}$ & $\begin{array}{r}0.1277^{* * *} \\
(0.0146)\end{array}$ & $\begin{array}{r}90.98 \% \\
{[78.82 \%]}\end{array}$ & 0.866 & $\begin{array}{r}96 \\
{[639]}\end{array}$ \\
\hline $\begin{array}{l}\text { Democracy } \\
\text { (Reduced sample) }\end{array}$ & $\begin{array}{r}0.0237 \\
(0.0179)\end{array}$ & $\begin{array}{r}0.0315 \\
(0.0196)\end{array}$ & $\begin{array}{r}0.0253 \\
(0.0201)\end{array}$ & $\begin{array}{r}93.12 \% \\
{[48.87 \%]}\end{array}$ & 0.525 & $\begin{array}{r}86 \\
{[516]}\end{array}$ \\
\hline $\begin{array}{l}\text { Democracy } \\
\text { (Main specifications) }\end{array}$ & $\begin{array}{r}0.0539^{* * *} \\
(0.0165)\end{array}$ & $\begin{array}{r}0.0344^{* * * *} \\
(0.0066)\end{array}$ & $\begin{array}{r}0.0556^{* * *} \\
(0.0138)\end{array}$ & $\begin{array}{r}96.76 \% \\
{[96.23 \%]}\end{array}$ & 0.995 & $\begin{array}{r}144 \\
{[895]}\end{array}$ \\
\hline
\end{tabular}

Notes: Standard errors in round parentheses, as indicated in columns' headers. Model specifications including quadratic or interacted terms of democracy are excluded from the sample.

Significance levels $* * * 0.001 * * 0.01 * 0.05$ 
Table B.2: Meta-analysis, excluding zero-order correlations

\begin{tabular}{|c|c|c|c|c|c|c|}
\hline & $\begin{array}{c}\text { RE ML } \\
\text { (s.e.) }\end{array}$ & $\begin{array}{c}\text { FE } \\
\text { (clustered s.e.) }\end{array}$ & $\begin{array}{c}\text { RE } \\
\text { (clustered s.e.) }\end{array}$ & $\begin{array}{c}\text { Total Î2 } \\
{[\text { Between Îे] }}\end{array}$ & ICC & $\begin{array}{c}\text { Studies } \\
\text { [Effect sizes] }\end{array}$ \\
\hline Democracy & $\begin{array}{r}0.0415^{* *} \\
(0.0133)\end{array}$ & $\begin{array}{r}0.0336^{* * * *} \\
(0.0041)\end{array}$ & $\begin{array}{r}0.0456 * * \\
(0.0151)\end{array}$ & $\begin{array}{r}97.77 \% \\
{[86.35 \%]}\end{array}$ & 0.883 & $\begin{array}{r}185 \\
{[2040]}\end{array}$ \\
\hline
\end{tabular}

Notes: Standard errors in round parentheses, as indicated in columns' headers. The sample excludes zero-order correlations. Significance levels $* * * 0.001 * * 0.01 * 0.05$ 


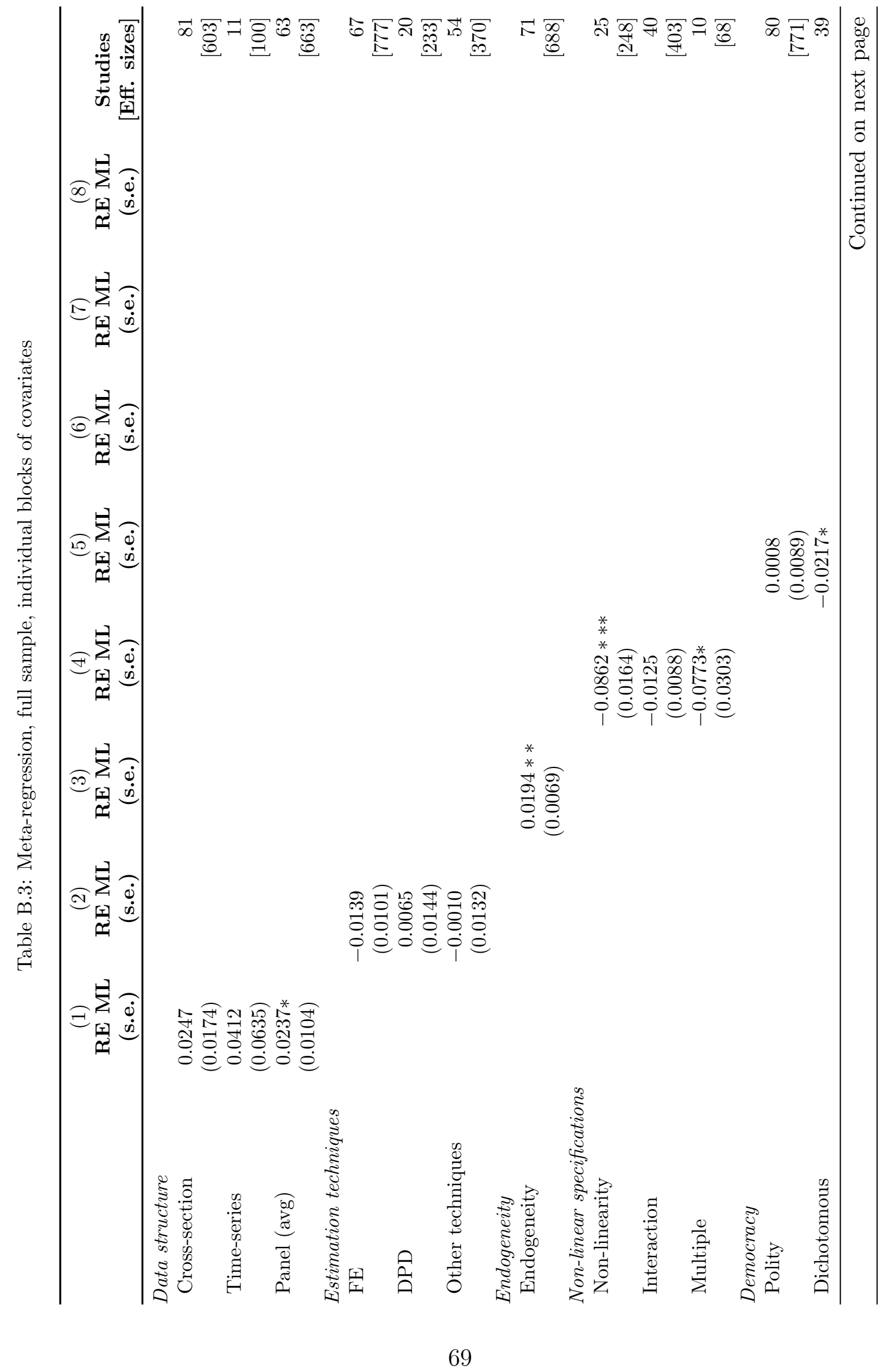




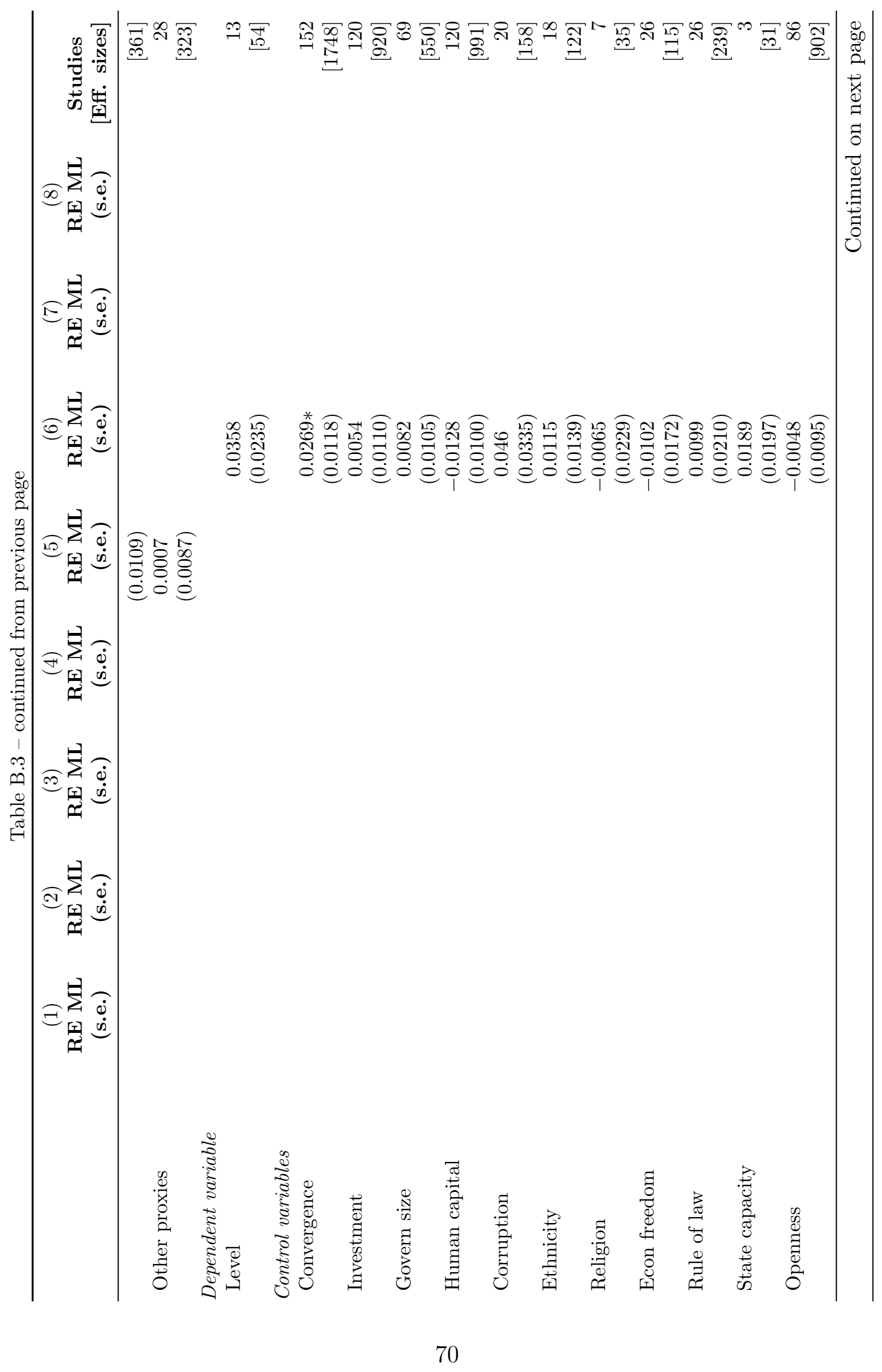




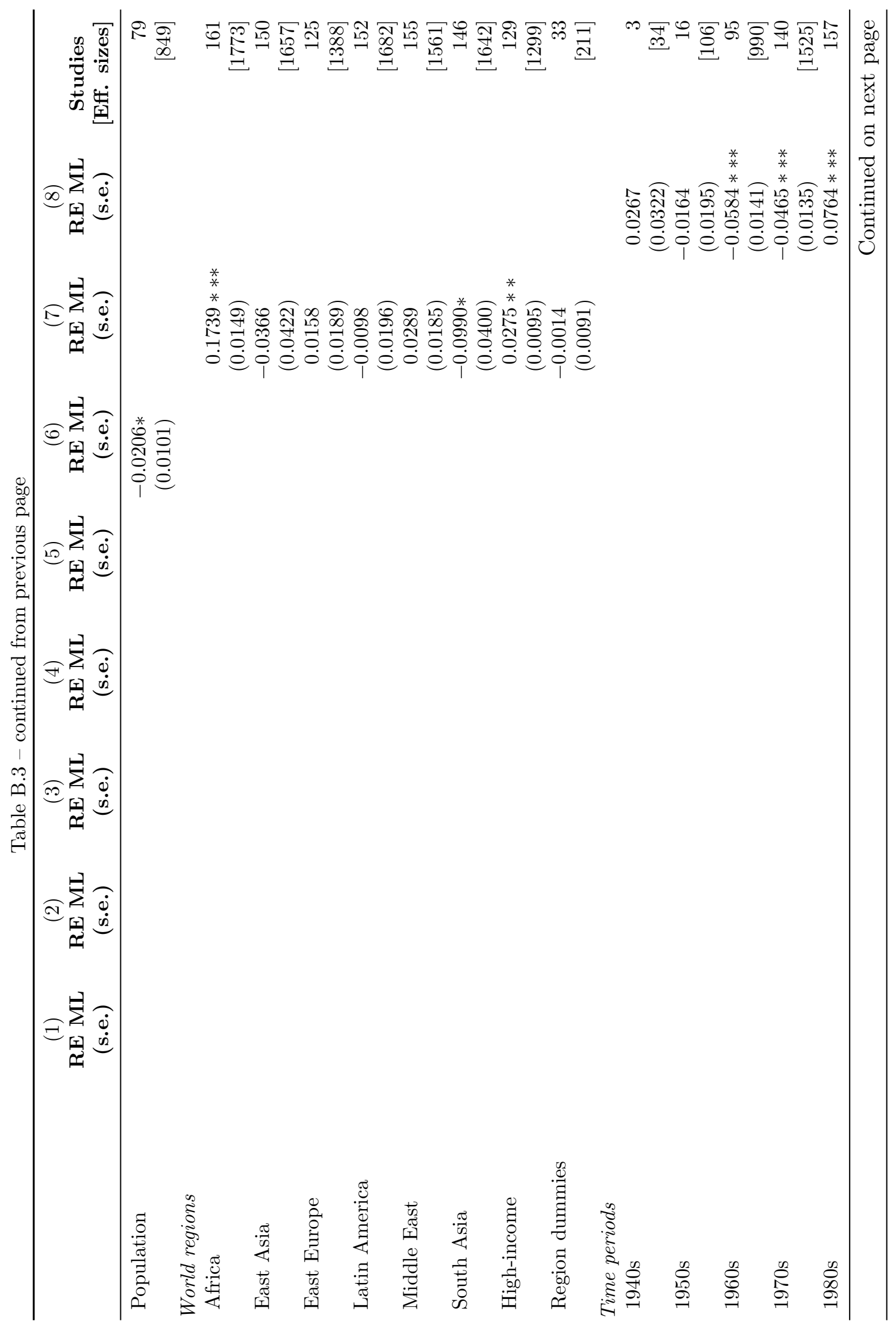




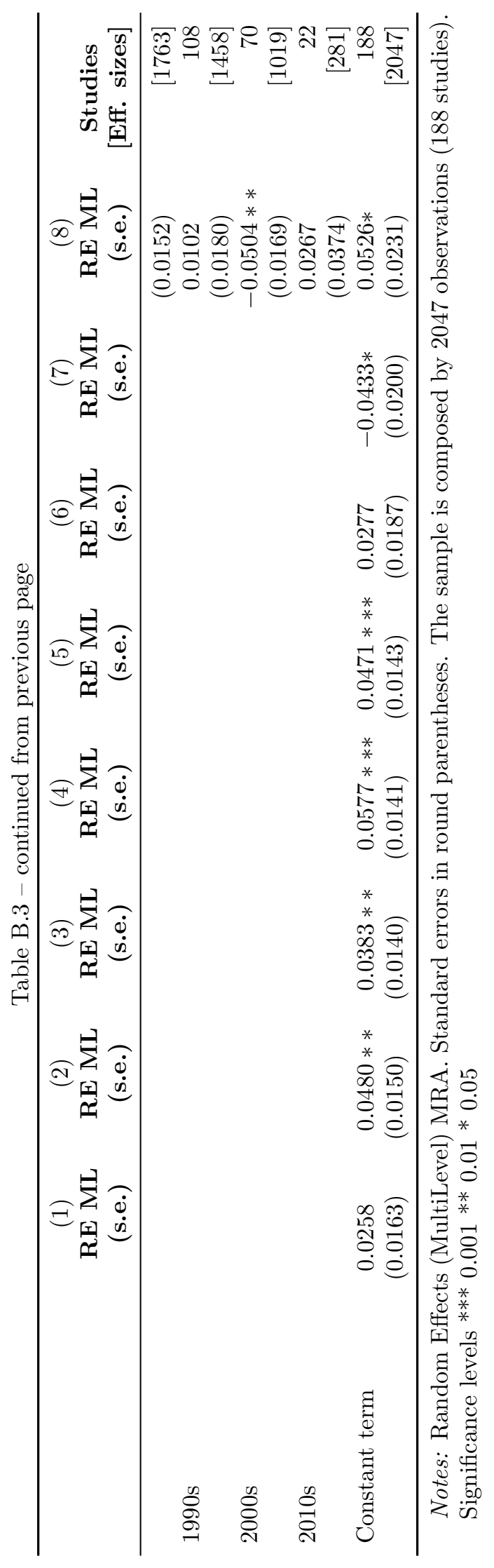


Table B.4: Meta-regression, full sample, uncorrected partial correlations

\begin{tabular}{|c|c|c|c|c|c|}
\hline & $\begin{array}{c}(1) \\
\text { RE ML } \\
\text { (s.e.) }\end{array}$ & $\begin{array}{c}(2) \\
\text { FE } \\
\text { (clus. s.e.) }\end{array}$ & $\begin{array}{c}(3) \\
\text { UWLS } \\
\text { (clus. s.e.) }\end{array}$ & $\begin{array}{c}(4) \\
\text { RE } \\
\text { (clus. s.e.) }\end{array}$ & $\begin{array}{c}\text { Studies } \\
\text { [Eff. sizes] }\end{array}$ \\
\hline \multicolumn{6}{|l|}{ Data structure } \\
\hline Cross-section & $\begin{array}{l}0.0708 * * * \\
(0.0213)\end{array}$ & $\begin{array}{c}0.0874 * \\
(0.0390)\end{array}$ & $\begin{array}{c}0.0874 * \\
(0.0348)\end{array}$ & $\begin{array}{c}0.0524 \\
(0.0314)\end{array}$ & $\begin{array}{r}81 \\
{[603]}\end{array}$ \\
\hline Time-series & $\begin{array}{c}0.1218 \\
(0.0717)\end{array}$ & $\begin{array}{l}0.4801 * * \\
(0.1729)\end{array}$ & $\begin{array}{l}0.4801 * * \\
(0.1543)\end{array}$ & $\begin{array}{c}0.394 * * \\
(0.1278)\end{array}$ & $\begin{array}{r}11 \\
{[100]}\end{array}$ \\
\hline Panel (avg) & $\begin{array}{r}0.0266 * \\
(0.0108)\end{array}$ & $\begin{array}{c}0.0350 \\
(0.0239)\end{array}$ & $\begin{array}{c}0.035 \\
(0.0213)\end{array}$ & $\begin{array}{c}0.0465 * \\
(0.0228)\end{array}$ & $\begin{array}{r}63 \\
{[663]}\end{array}$ \\
\hline \multicolumn{6}{|c|}{ Estimation techniques } \\
\hline $\mathrm{FE}$ & $\begin{array}{c}-0.0092 \\
(0.0138)\end{array}$ & $\begin{array}{c}-0.0019 \\
(0.0222)\end{array}$ & $\begin{array}{c}-0.0019 \\
(0.0198)\end{array}$ & $\begin{array}{c}-0.0493 \\
(0.0317)\end{array}$ & $\begin{array}{r}67 \\
{[777]}\end{array}$ \\
\hline DPD & $\begin{array}{c}0.0108 \\
(0.0178)\end{array}$ & $\begin{array}{c}-0.0232 \\
(0.0279)\end{array}$ & $\begin{array}{c}-0.0232 \\
(0.0249)\end{array}$ & $\begin{array}{r}-0.1058 * \\
(0.0439)\end{array}$ & $\begin{array}{r}20 \\
{[233]}\end{array}$ \\
\hline Other techniques & $\begin{array}{c}0.0034 \\
(0.0144)\end{array}$ & $\begin{array}{c}0.0194 \\
(0.0239)\end{array}$ & $\begin{array}{c}0.0194 \\
(0.0214)\end{array}$ & $\begin{array}{c}-0.0218 \\
(0.0312)\end{array}$ & $\begin{array}{r}54 \\
{[370]}\end{array}$ \\
\hline \multicolumn{6}{|c|}{ Non-linear specifications } \\
\hline Non-linearity & $\begin{array}{c}-0.0745 * * * \\
(0.0162)\end{array}$ & $\begin{array}{c}-0.0661 \\
(0.0391)\end{array}$ & $\begin{array}{r}-0.0661 . \\
(0.0349)\end{array}$ & $\begin{array}{c}-0.0957 * * \\
(0.0362)\end{array}$ & $\begin{array}{r}25 \\
{[248]}\end{array}$ \\
\hline Interaction & $\begin{array}{c}-0.0107 \\
(0.0089)\end{array}$ & $\begin{array}{c}0.0023 \\
(0.0121)\end{array}$ & $\begin{array}{c}0.0023 \\
(0.0108)\end{array}$ & $\begin{array}{c}-0.0084 \\
(0.0217)\end{array}$ & $\begin{array}{r}40 \\
{[403]}\end{array}$ \\
\hline Multiple & $\begin{array}{c}-0.1128 * * * \\
(0.0326)\end{array}$ & $\begin{array}{c}-0.0571 \\
(0.0346)\end{array}$ & $\begin{array}{r}-0.0571 . \\
(0.0309)\end{array}$ & $\begin{array}{c}-0.0391 \\
(0.0314)\end{array}$ & $\begin{array}{r}10 \\
{[68]}\end{array}$ \\
\hline \multicolumn{6}{|l|}{ Dependent variable } \\
\hline Level & $\begin{array}{c}0.0298 \\
(0.026)\end{array}$ & $\begin{array}{c}-0.0217 \\
(0.0295)\end{array}$ & $\begin{array}{c}-0.0217 \\
(0.0263)\end{array}$ & $\begin{array}{c}-0.0273 \\
(0.0835)\end{array}$ & $\begin{array}{r}13 \\
{[54]}\end{array}$ \\
\hline \multicolumn{6}{|l|}{ Democracy } \\
\hline Polity & $\begin{array}{c}-0.0003 \\
(0.0088)\end{array}$ & $\begin{array}{c}0.0024 \\
(0.0200)\end{array}$ & $\begin{array}{c}0.0024 \\
(0.0178)\end{array}$ & $\begin{array}{c}-0.0132 \\
(0.0178)\end{array}$ & $\begin{array}{r}80 \\
{[771]}\end{array}$ \\
\hline Dichotomous & $\begin{array}{c}-0.0169 \\
(0.0112)\end{array}$ & $\begin{array}{c}0.0119 \\
(0.0158)\end{array}$ & $\begin{array}{c}0.0119 \\
(0.0141)\end{array}$ & $\begin{array}{c}0.0228 \\
(0.0219)\end{array}$ & $\begin{array}{r}39 \\
{[361]}\end{array}$ \\
\hline Other proxies & $\begin{array}{c}0.0003 \\
(0.0086)\end{array}$ & $\begin{array}{c}-0.0125 \\
(0.0116)\end{array}$ & $\begin{array}{c}-0.0125 \\
(0.0104)\end{array}$ & $\begin{array}{c}0.0033 \\
(0.0233)\end{array}$ & $\begin{array}{r}28 \\
{[323]}\end{array}$ \\
\hline \multicolumn{6}{|l|}{ Control variables } \\
\hline Convergence & $\begin{array}{l}0.0341 * * \\
(0.0128)\end{array}$ & $\begin{array}{c}0.0198 \\
(0.0197)\end{array}$ & $\begin{array}{c}0.0198 \\
(0.0176)\end{array}$ & $\begin{array}{c}0.0288 \\
(0.0326)\end{array}$ & $\begin{array}{r}152 \\
{[1748]}\end{array}$ \\
\hline Investment & $\begin{array}{c}0.0018 \\
(0.0104)\end{array}$ & $\begin{array}{r}-0.0570 * \\
(0.0285)\end{array}$ & $\begin{array}{c}-0.057 * \\
(0.0255)\end{array}$ & $\begin{array}{c}-0.0577 * * \\
(0.0206)\end{array}$ & $\begin{array}{r}120 \\
{[920]}\end{array}$ \\
\hline Govern size & $\begin{array}{c}0.0185 \\
(0.0106)\end{array}$ & $\begin{array}{c}0.0165 \\
(0.0195)\end{array}$ & $\begin{array}{c}0.0165 \\
(0.0174)\end{array}$ & $\begin{array}{c}0.0243 \\
(0.0216)\end{array}$ & $\begin{array}{r}69 \\
{[550]}\end{array}$ \\
\hline Human capital & $\begin{array}{c}-0.0059 \\
(0.0102)\end{array}$ & $\begin{array}{c}-0.0015 \\
(0.0166)\end{array}$ & $\begin{array}{c}-0.0015 \\
(0.0148)\end{array}$ & $\begin{array}{c}-0.0218 \\
(0.0205)\end{array}$ & $\begin{array}{r}120 \\
{[991]}\end{array}$ \\
\hline Corruption & $\begin{array}{c}0.0133 \\
(0.0354)\end{array}$ & $\begin{array}{c}0.0307 \\
(0.0244)\end{array}$ & $\begin{array}{c}0.0307 \\
(0.0218)\end{array}$ & $\begin{array}{c}0.0341 \\
(0.0345)\end{array}$ & $\begin{array}{r}20 \\
{[158]}\end{array}$ \\
\hline Ethnicity & 0.004 & -0.0399 & -0.0399 & $-0.0544 *$ & 18 \\
\hline
\end{tabular}


Table B.4 - continued from previous page

\begin{tabular}{|c|c|c|c|c|c|}
\hline & $\begin{array}{c}(1) \\
\text { RE ML } \\
\text { (s.e.) }\end{array}$ & $\begin{array}{c}(2) \\
\text { FE } \\
\text { (clus. s.e.) }\end{array}$ & $\begin{array}{c}(3) \\
\text { UWLS } \\
\text { (clus. s.e.) }\end{array}$ & $\begin{array}{c}(4) \\
\mathbf{R E} \\
\text { (clus. s.e.) }\end{array}$ & $\begin{array}{l}\text { Studies } \\
\text { [Eff. sizes] }\end{array}$ \\
\hline & $(0.0165)$ & $(0.0236)$ & $(0.0211)$ & $(0.0256)$ & {$[122]$} \\
\hline Religion & $\begin{array}{r}-0.0137 \\
(0.0233)\end{array}$ & $\begin{array}{c}0.0311 \\
(0.0335)\end{array}$ & $\begin{array}{c}0.0311 \\
(0.0299)\end{array}$ & $\begin{array}{c}0.0776 \\
(0.0549)\end{array}$ & $\begin{array}{r}7 \\
{[35]}\end{array}$ \\
\hline Econ freedom & $\begin{array}{c}-0.0199 \\
(0.0177)\end{array}$ & $\begin{array}{c}-0.0352 * \\
(0.0170)\end{array}$ & $\begin{array}{c}-0.0352 * \\
(0.0152)\end{array}$ & $\begin{array}{c}-0.0264 \\
(0.0346)\end{array}$ & $\begin{array}{r}26 \\
{[115]}\end{array}$ \\
\hline Rule of law & $\begin{array}{c}-0.0118 \\
(0.0216)\end{array}$ & $\begin{array}{c}-0.0321 \\
(0.0290)\end{array}$ & $\begin{array}{c}-0.0321 \\
(0.0258)\end{array}$ & $\begin{array}{c}0.0153 \\
(0.0298)\end{array}$ & $\begin{array}{r}26 \\
{[239]}\end{array}$ \\
\hline State capacity & $\begin{array}{l}0.0637 * * \\
(0.0222)\end{array}$ & $\begin{array}{r}0.0395 * \\
(0.0167)\end{array}$ & $\begin{array}{l}0.0395 * * \\
(0.0149)\end{array}$ & $\begin{array}{c}0.047 \\
(0.0495)\end{array}$ & $\begin{array}{r}3 \\
{[31]}\end{array}$ \\
\hline Openness & $\begin{array}{c}-0.0043 \\
(0.0097)\end{array}$ & $\begin{array}{c}0.0112 \\
(0.0167)\end{array}$ & $\begin{array}{c}0.0112 \\
(0.0149)\end{array}$ & $\begin{array}{c}0.0282 \\
(0.0211)\end{array}$ & $\begin{array}{r}86 \\
{[902]}\end{array}$ \\
\hline Population & $\begin{array}{c}-0.0269 * \\
(0.0108)\end{array}$ & $\begin{array}{c}0.0046 \\
(0.0175)\end{array}$ & $\begin{array}{c}0.0046 \\
(0.0156)\end{array}$ & $\begin{array}{c}-0.0125 \\
(0.0203)\end{array}$ & $\begin{array}{r}79 \\
{[849]}\end{array}$ \\
\hline \multicolumn{6}{|l|}{ World regions } \\
\hline Africa & $\begin{array}{l}0.2155 * * * \\
(0.0148)\end{array}$ & $\begin{array}{c}0.1212 \\
(0.0634)\end{array}$ & $\begin{array}{r}0.1212 * \\
(0.0566)\end{array}$ & $\begin{array}{c}0.19 * \\
(0.0823)\end{array}$ & $\begin{array}{r}161 \\
{[1773]}\end{array}$ \\
\hline East Asia & $\begin{array}{c}-0.0582 \\
(0.0446)\end{array}$ & $\begin{array}{c}0.0752 \\
(0.1069)\end{array}$ & $\begin{array}{c}0.0752 \\
(0.0954)\end{array}$ & $\begin{array}{c}0.0435 \\
(0.1023)\end{array}$ & $\begin{array}{r}150 \\
{[1657]}\end{array}$ \\
\hline East Europe & $\begin{array}{c}0.0181 \\
(0.0191)\end{array}$ & $\begin{array}{c}-0.0499 \\
(0.0540)\end{array}$ & $\begin{array}{c}-0.0499 \\
(0.0482)\end{array}$ & $\begin{array}{c}0.0311 \\
(0.0364)\end{array}$ & $\begin{array}{r}125 \\
{[1388]}\end{array}$ \\
\hline Latin America & $\begin{array}{r}-0.0172 \\
(0.0199)\end{array}$ & $\begin{array}{c}0.0254 \\
(0.0366)\end{array}$ & $\begin{array}{c}0.0254 \\
(0.0327)\end{array}$ & $\begin{array}{c}0.0601 \\
(0.054)\end{array}$ & $\begin{array}{r}152 \\
{[1682]}\end{array}$ \\
\hline Middle East & $\begin{array}{r}0.0449 * \\
(0.0187)\end{array}$ & $\begin{array}{c}0.0807 \\
(0.0672)\end{array}$ & $\begin{array}{c}0.0807 \\
(0.06)\end{array}$ & $\begin{array}{c}0.0340 \\
(0.0515)\end{array}$ & $\begin{array}{r}155 \\
{[1561]}\end{array}$ \\
\hline South Asia & $\begin{array}{c}-0.1258 * * \\
(0.0427)\end{array}$ & $\begin{array}{c}-0.1503 \\
(0.1062)\end{array}$ & $\begin{array}{r}-0.1503 \\
(0.0948)\end{array}$ & $\begin{array}{c}-0.2527 * * \\
(0.0822)\end{array}$ & $\begin{array}{r}146 \\
{[1642]}\end{array}$ \\
\hline High-income & $\begin{array}{l}0.0309 * * \\
(0.0096)\end{array}$ & $\begin{array}{c}-0.0140 \\
(0.0154)\end{array}$ & $\begin{array}{c}-0.014 \\
(0.0138)\end{array}$ & $\begin{array}{c}0.0017 \\
(0.0226)\end{array}$ & $\begin{array}{r}129 \\
{[1299]}\end{array}$ \\
\hline Region dummies & $\begin{array}{c}-0.0056 \\
(0.0104)\end{array}$ & $\begin{array}{c}0.0065 \\
(0.0086)\end{array}$ & $\begin{array}{c}0.0065 \\
(0.0077)\end{array}$ & $\begin{array}{c}0.0189 \\
(0.0205)\end{array}$ & $\begin{array}{r}33 \\
{[211]}\end{array}$ \\
\hline Time periods & & & & & \\
\hline $1940 \mathrm{~s}$ & $\begin{array}{c}0.0434 \\
(0.0337)\end{array}$ & $\begin{array}{c}-0.0792 \\
(0.0439)\end{array}$ & $\begin{array}{r}-0.0792 * \\
(0.0392)\end{array}$ & $\begin{array}{r}-0.2258 \\
(0.1471)\end{array}$ & $\begin{array}{r}3 \\
{[34]}\end{array}$ \\
\hline $1950 \mathrm{~s}$ & $\begin{array}{c}-0.002 \\
(0.0211)\end{array}$ & $\begin{array}{c}0.0314 * \\
(0.0136)\end{array}$ & $\begin{array}{l}0.0314 * * \\
(0.0121)\end{array}$ & $\begin{array}{c}0.0609 \\
(0.0313)\end{array}$ & $\begin{array}{r}16 \\
{[106]}\end{array}$ \\
\hline $1960 \mathrm{~s}$ & $\begin{array}{c}-0.0751 * * * \\
(0.0148)\end{array}$ & $\begin{array}{c}-0.0337 \\
(0.0210)\end{array}$ & $\begin{array}{r}-0.0337 \\
(0.0188)\end{array}$ & $\begin{array}{c}-0.0430 \\
(0.0254)\end{array}$ & $\begin{array}{r}95 \\
{[990]}\end{array}$ \\
\hline $1970 \mathrm{~s}$ & $\begin{array}{c}-0.0494 * * * \\
(0.0146)\end{array}$ & $\begin{array}{c}-0.0223 \\
(0.0292)\end{array}$ & $\begin{array}{c}-0.0223 \\
(0.0261)\end{array}$ & $\begin{array}{c}-0.0176 \\
(0.0297)\end{array}$ & $\begin{array}{r}140 \\
{[1525]}\end{array}$ \\
\hline $1980 \mathrm{~s}$ & $\begin{array}{l}0.0904 * * * \\
(0.0164)\end{array}$ & $\begin{array}{r}0.0728 * \\
(0.0360)\end{array}$ & $\begin{array}{r}0.0728 * \\
(0.0321)\end{array}$ & $\begin{array}{c}0.0618 \\
(0.0382)\end{array}$ & $\begin{array}{r}157 \\
{[1763]}\end{array}$ \\
\hline 1990s & $\begin{array}{c}0.0148 \\
(0.0187)\end{array}$ & $\begin{array}{c}0.0254 \\
(0.0252)\end{array}$ & $\begin{array}{c}0.0254 \\
(0.0224)\end{array}$ & $\begin{array}{c}0.0184 \\
(0.0280)\end{array}$ & $\begin{array}{r}108 \\
{[1458]}\end{array}$ \\
\hline $2000 \mathrm{~s}$ & $-0.0386 *$ & -0.0098 & -0.0098 & -0.0225 & 70 \\
\hline
\end{tabular}


Table B.4 - continued from previous page

\begin{tabular}{|c|c|c|c|c|c|}
\hline & $\begin{array}{c}(1) \\
\text { RE ML } \\
\text { (s.e.) }\end{array}$ & $\begin{array}{c}(2) \\
\text { FE } \\
\text { (clus. s.e.) }\end{array}$ & $\begin{array}{c}(3) \\
\text { UWLS } \\
\text { (clus. s.e.) }\end{array}$ & $\begin{array}{c}(4) \\
\text { RE } \\
\text { (clus. s.e.) }\end{array}$ & $\begin{array}{c}\text { Studies } \\
\text { [Eff. sizes] }\end{array}$ \\
\hline & $(0.0189)$ & $(0.0189)$ & $(0.0169)$ & $(0.0300)$ & [1019] \\
\hline \multirow[t]{2}{*}{$2010 \mathrm{~s}$} & 0.0003 & $0.0756 *$ & $0.0756 *$ & $0.0994 *$ & 22 \\
\hline & $(0.0397)$ & $(0.0380)$ & $(0.0339)$ & $(0.0392)$ & [281] \\
\hline \multirow[t]{2}{*}{ Constant term } & $-0.0928 *$ & -0.1264 & -0.1264 & -0.0853 & 188 \\
\hline & $(0.0374)$ & $(0.0906)$ & $(0.0809)$ & $(0.0754)$ & {$[2047]$} \\
\hline
\end{tabular}

Notes: Standard errors in round parentheses as indicated in column headers. The sample is composed by 2047 observations (188 studies). The dependent variable is the raw partial correlation.

Significance levels $* * * 0.001 * * 0.01 * 0.05$ 
Table B.5: Meta-regression, main specifications only

\begin{tabular}{|c|c|c|c|c|c|}
\hline & $\begin{array}{c}(1) \\
\text { RE ML } \\
\text { (s.e.) }\end{array}$ & $\begin{array}{c}(2) \\
\text { FE } \\
\text { (clus. s.e.) }\end{array}$ & $\begin{array}{c}(3) \\
\text { UWLS } \\
\text { (clus. s.e.) }\end{array}$ & $\begin{array}{c}(4) \\
\text { RE } \\
\text { (clus. s.e.) }\end{array}$ & $\begin{array}{c}\text { Studies } \\
\text { [Eff. sizes] }\end{array}$ \\
\hline \multicolumn{6}{|l|}{ Data Structure } \\
\hline Cross-section & $\begin{array}{c}0.0755 * \\
(0.0320)\end{array}$ & $\begin{array}{c}0.0671 \\
(0.0342)\end{array}$ & $\begin{array}{c}0.0671 * \\
(0.0305)\end{array}$ & $\begin{array}{c}0.0718 * \\
(0.0355)\end{array}$ & $\begin{array}{r}77 \\
{[460]}\end{array}$ \\
\hline Time-series & $\begin{array}{c}0.1224 \\
(0.0762)\end{array}$ & $\begin{array}{c}0.1451 \\
(0.2234)\end{array}$ & $\begin{array}{c}0.1451 \\
(0.1995)\end{array}$ & $\begin{array}{c}0.2704 \\
(0.1679)\end{array}$ & $\begin{array}{r}11 \\
{[58]}\end{array}$ \\
\hline Panel (avg) & $\begin{array}{c}0.0465 \\
(0.0324)\end{array}$ & $\begin{array}{c}0.0324 \\
(0.0203)\end{array}$ & $\begin{array}{c}0.0324 \\
(0.0182)\end{array}$ & $\begin{array}{c}0.069 * \\
(0.0288)\end{array}$ & $\begin{array}{r}56 \\
{[396]}\end{array}$ \\
\hline \multicolumn{6}{|c|}{ Estimation techniques } \\
\hline $\mathrm{FE}$ & $\begin{array}{c}-0.0004 \\
(0.0213)\end{array}$ & $\begin{array}{c}-0.0146 \\
(0.02)\end{array}$ & $\begin{array}{c}-0.0146 \\
(0.0178)\end{array}$ & $\begin{array}{c}-0.0628 \\
(0.0353)\end{array}$ & $\begin{array}{r}61 \\
{[357]}\end{array}$ \\
\hline DPD & $\begin{array}{c}0.0549 \\
(0.0343)\end{array}$ & $\begin{array}{c}-0.0428 \\
(0.0341)\end{array}$ & $\begin{array}{c}-0.0428 \\
(0.0304)\end{array}$ & $\begin{array}{c}-0.0844 \\
(0.0558)\end{array}$ & $\begin{array}{r}16 \\
{[88]}\end{array}$ \\
\hline Other techniques & $\begin{array}{c}0.0086 \\
(0.0207)\end{array}$ & $\begin{array}{c}0.0309 \\
(0.0234)\end{array}$ & $\begin{array}{c}0.0309 \\
(0.0209)\end{array}$ & $\begin{array}{c}-0.0325 \\
(0.0347)\end{array}$ & $\begin{array}{r}47 \\
{[265]}\end{array}$ \\
\hline \multicolumn{6}{|c|}{ Non-linear specifications } \\
\hline Non-linearity & $\begin{array}{c}-0.0675 * * \\
(0.0223)\end{array}$ & $\begin{array}{c}-0.0288 \\
(0.0234)\end{array}$ & $\begin{array}{c}-0.0288 \\
(0.0209)\end{array}$ & $\begin{array}{c}-0.0926 * \\
(0.0421)\end{array}$ & $\begin{array}{r}24 \\
{[120]}\end{array}$ \\
\hline Interaction term & $\begin{array}{r}-0.0325 \\
(0.0180)\end{array}$ & $\begin{array}{r}-0.0013 \\
(0.0114)\end{array}$ & $\begin{array}{c}-0.0013 \\
(0.0102)\end{array}$ & $\begin{array}{c}-0.0305 \\
(0.0314)\end{array}$ & $\begin{array}{r}36 \\
{[173]}\end{array}$ \\
\hline Multiple Dem & $\begin{array}{c}-0.1293 * * \\
(0.0396)\end{array}$ & $\begin{array}{r}-0.0408 \\
(0.026)\end{array}$ & $\begin{array}{c}-0.0408 \\
(0.0232)\end{array}$ & $\begin{array}{c}-0.0651 \\
(0.0384)\end{array}$ & $\begin{array}{r}10 \\
{[68]}\end{array}$ \\
\hline \multicolumn{6}{|l|}{ Dependent variable } \\
\hline Democracu & $\begin{array}{c}0.0143 \\
(0.0394)\end{array}$ & $\begin{array}{c}-0.0173 \\
(0.0351)\end{array}$ & $\begin{array}{c}-0.0173 \\
(0.0314)\end{array}$ & $\begin{array}{c}-0.0482 \\
(0.0892)\end{array}$ & $\begin{array}{r}11 \\
{[37]}\end{array}$ \\
\hline \multicolumn{6}{|l|}{ Democracy } \\
\hline Polity & $\begin{array}{c}-0.008 \\
(0.0151)\end{array}$ & $\begin{array}{c}-0.007 \\
(0.0179)\end{array}$ & $\begin{array}{r}-0.007 \\
(0.016)\end{array}$ & $\begin{array}{c}-0.0213 \\
(0.0243)\end{array}$ & $\begin{array}{r}73 \\
{[446]}\end{array}$ \\
\hline Dichotomous & $\begin{array}{c}-0.0015 \\
(0.0216)\end{array}$ & $\begin{array}{c}0.0085 \\
(0.0177)\end{array}$ & $\begin{array}{c}0.0085 \\
(0.0158)\end{array}$ & $\begin{array}{c}0.0334 \\
(0.0272)\end{array}$ & $\begin{array}{r}33 \\
{[205]}\end{array}$ \\
\hline Other proxies & $\begin{array}{c}-0.0078 \\
(0.0223)\end{array}$ & $\begin{array}{c}-0.012 \\
(0.0152)\end{array}$ & $\begin{array}{c}-0.012 \\
(0.0136)\end{array}$ & $\begin{array}{c}0.0141 \\
(0.0327)\end{array}$ & $\begin{array}{r}22 \\
{[122]}\end{array}$ \\
\hline \multicolumn{6}{|l|}{ Control variables } \\
\hline Convergence & $\begin{array}{c}0.0181 \\
(0.0208)\end{array}$ & $\begin{array}{c}0.0001 \\
(0.0152)\end{array}$ & $\begin{array}{c}0.0001 \\
(0.0136)\end{array}$ & $\begin{array}{c}-0.001 \\
(0.031)\end{array}$ & $\begin{array}{r}146 \\
{[1025]}\end{array}$ \\
\hline Investment & $\begin{array}{c}-0.0142 \\
(0.0173)\end{array}$ & $\begin{array}{r}-0.0327 \\
(0.0195)\end{array}$ & $\begin{array}{c}-0.0327 \\
(0.0174)\end{array}$ & $\begin{array}{c}-0.0615 * \\
(0.0263)\end{array}$ & $\begin{array}{r}110 \\
{[636]}\end{array}$ \\
\hline Govern size & $\begin{array}{c}0.0098 \\
(0.0184)\end{array}$ & $\begin{array}{c}0.0009 \\
(0.0151)\end{array}$ & $\begin{array}{c}0.0009 \\
(0.0135)\end{array}$ & $\begin{array}{c}0.0264 \\
(0.023)\end{array}$ & $\begin{array}{r}63 \\
{[341]}\end{array}$ \\
\hline Human capital & $\begin{array}{c}-0.0087 \\
(0.0194)\end{array}$ & $\begin{array}{c}-0.0022 \\
(0.017)\end{array}$ & $\begin{array}{c}-0.0022 \\
(0.0152)\end{array}$ & $\begin{array}{c}-0.0243 \\
(0.0231)\end{array}$ & $\begin{array}{r}110 \\
{[722]}\end{array}$ \\
\hline Corruption & $\begin{array}{c}0.0360 \\
(0.0404)\end{array}$ & $\begin{array}{c}-0.0069 \\
(0.0292)\end{array}$ & $\begin{array}{c}-0.0069 \\
(0.0261)\end{array}$ & $\begin{array}{c}0.0274 \\
(0.0462)\end{array}$ & $\begin{array}{r}19 \\
{[102]}\end{array}$ \\
\hline Ethnicity & 0.0168 & -0.0297 & -0.0297 & -0.0379 & 16 \\
\hline
\end{tabular}


Table B.5 - continued from previous page

\begin{tabular}{|c|c|c|c|c|c|}
\hline & $\begin{array}{c}(1) \\
\text { RE ML } \\
\text { (s.e.) }\end{array}$ & $\begin{array}{c}(2) \\
\text { FE } \\
\text { (clus. s.e.) }\end{array}$ & $\begin{array}{c}(3) \\
\text { UWLS } \\
\text { (clus. s.e.) }\end{array}$ & $\begin{array}{c}(4) \\
\text { RE } \\
\text { (clus. s.e.) }\end{array}$ & $\begin{array}{c}\text { Studies } \\
\text { [Eff. sizes] }\end{array}$ \\
\hline & $(0.0254)$ & (0.0209) & $(0.0187)$ & $(0.031)$ & {$[65]$} \\
\hline \multirow[t]{2}{*}{ Religion } & 0.0010 & 0.0267 & 0.0267 & 0.1054 & 5 \\
\hline & $(0.0444)$ & $(0.0324)$ & $(0.0289)$ & $(0.0576)$ & [21] \\
\hline \multirow[t]{2}{*}{ Econ freedom } & 0.0299 & -0.0115 & -0.0115 & 0.0153 & 22 \\
\hline & $(0.0337)$ & $(0.0219)$ & $(0.0196)$ & $(0.0296)$ & [87] \\
\hline \multirow[t]{2}{*}{ Rule of law } & 0.0188 & -0.0076 & -0.0076 & 0.013 & 24 \\
\hline & $(0.0279)$ & $(0.0298)$ & $(0.0266)$ & $(0.0354)$ & [139] \\
\hline \multirow{2}{*}{ State capacity } & 0.0131 & 0.0399 & 0.0399 & 0.0316 & 3 \\
\hline & $(0.0418)$ & $(0.0247)$ & $(0.0221)$ & $(0.0852)$ & [16] \\
\hline \multirow[t]{2}{*}{ Openness } & 0.0143 & 0.0067 & 0.0067 & $0.0512 *$ & 76 \\
\hline & $(0.0196)$ & (0.0198) & $(0.0177)$ & $(0.0248)$ & [489] \\
\hline \multirow[t]{2}{*}{ Population } & -0.0271 & -0.0163 & -0.0163 & -0.0199 & 74 \\
\hline & $(0.0181)$ & $(0.0141)$ & $(0.0126)$ & $(0.0237)$ & [497] \\
\hline \multicolumn{6}{|l|}{ World regions } \\
\hline \multirow[t]{2}{*}{ Africa } & $0.1595 * * *$ & 0.0462 & 0.0462 & 0.1372 & 153 \\
\hline & $(0.0214)$ & $(0.0293)$ & $(0.0262)$ & $(0.0717)$ & [997] \\
\hline \multirow[t]{2}{*}{ East Asia } & 0.0093 & 0.0081 & 0.0081 & 0.0482 & 144 \\
\hline & $(0.0501)$ & $(0.0601)$ & $(0.0536)$ & $(0.0892)$ & {$[947]$} \\
\hline \multirow[t]{2}{*}{ East Europe } & 0.0255 & -0.0091 & -0.0091 & 0.0267 & 120 \\
\hline & $(0.0246)$ & $(0.0186)$ & $(0.0166)$ & $(0.0339)$ & [768] \\
\hline \multirow[t]{2}{*}{ Latin America } & 0.0167 & -0.0052 & -0.0052 & 0.0529 & 145 \\
\hline & $(0.027)$ & $(0.0254)$ & $(0.0227)$ & $(0.0511)$ & [962] \\
\hline \multirow[t]{2}{*}{ Middle East } & 0.0131 & 0.0226 & 0.0226 & 0.0217 & 148 \\
\hline & $(0.0251)$ & $(0.0199)$ & $(0.0178)$ & $(0.0527)$ & [907] \\
\hline \multirow{2}{*}{ South Asia } & $-0.1262 * *$ & -0.0332 & -0.0332 & $-0.2037 *$ & 141 \\
\hline & $(0.0461)$ & $(0.0616)$ & $(0.055)$ & $(0.0825)$ & [926] \\
\hline \multirow[t]{2}{*}{ High-income } & 0.0215 & -0.0122 & -0.0122 & 0.0023 & 124 \\
\hline & $(0.0161)$ & $(0.0153)$ & $(0.0137)$ & $(0.0256)$ & [710] \\
\hline \multirow[t]{2}{*}{ Region dummies } & -0.0225 & 0.0127 & 0.0127 & 0.0165 & 23 \\
\hline & $(0.027)$ & $(0.0162)$ & $(0.0145)$ & $(0.0261)$ & [143] \\
\hline \multicolumn{6}{|l|}{ Time periods } \\
\hline \multirow[t]{2}{*}{$1940 \mathrm{~s}$} & 0.1734 & -0.1681 & -0.1681 & -0.204 & 2 \\
\hline & $(0.0961)$ & $(0.1876)$ & $(0.1675)$ & $(0.1968)$ & [16] \\
\hline \multirow[t]{2}{*}{$1950 \mathrm{~s}$} & 0.0346 & 0.0143 & 0.0143 & $0.0766 *$ & 15 \\
\hline & $(0.0367)$ & $(0.0156)$ & $(0.014)$ & $(0.0359)$ & [78] \\
\hline \multirow[t]{2}{*}{$1960 \mathrm{~s}$} & $-0.0400 *$ & -0.0158 & -0.0158 & -0.0384 & 89 \\
\hline & $(0.0201)$ & $(0.0176)$ & $(0.0157)$ & $(0.0255)$ & [517] \\
\hline \multirow[t]{2}{*}{$1970 \mathrm{~s}$} & -0.0378 & -0.0289 & -0.0289 & -0.0224 & 134 \\
\hline & $(0.0232)$ & $(0.0215)$ & $(0.0192)$ & $(0.0313)$ & [906] \\
\hline \multirow[t]{2}{*}{$1980 \mathrm{~s}$} & $0.0852 * *$ & $0.0613 *$ & $0.0613 *$ & 0.051 & 149 \\
\hline & $(0.0268)$ & $(0.0291)$ & $(0.026)$ & $(0.0394)$ & [1012] \\
\hline \multirow[t]{2}{*}{$1990 \mathrm{~s}$} & 0.013 & 0.0149 & 0.0149 & 0.0204 & 101 \\
\hline & $(0.0229)$ & $(0.0227)$ & $(0.0202)$ & (0.028) & [756] \\
\hline $2000 \mathrm{~s}$ & -0.0606 & 0.0015 & 0.0015 & -0.0181 & 67 \\
\hline
\end{tabular}


Table B.5 - continued from previous page

\begin{tabular}{|c|c|c|c|c|c|}
\hline & $\begin{array}{c}(1) \\
\text { RE ML } \\
\text { (s.e.) }\end{array}$ & $\begin{array}{c}(2) \\
\mathbf{F E} \\
\text { (clus. s.e.) }\end{array}$ & $\begin{array}{c}(3) \\
\text { UWLS } \\
\text { (clus. s.e.) }\end{array}$ & $\begin{array}{c}(4) \\
\mathbf{R E} \\
\text { (clus. s.e.) }\end{array}$ & $\begin{array}{c}\text { Studies } \\
{[\text { Eff. sizes }]}\end{array}$ \\
\hline \multirow{3}{*}{$2010 \mathrm{~s}$} & $(0.0334)$ & $(0.0192)$ & $(0.0171)$ & $(0.0317)$ & {$[441]$} \\
\hline & 0.0742 & 0.0458 & $0.0458 *$ & $0.1101 *$ & 22 \\
\hline & $(0.0442)$ & $(0.0239)$ & $(0.0214)$ & $(0.0452)$ & [124] \\
\hline \multirow[t]{2}{*}{ Constant term } & $-0.1189 *$ & -0.0123 & -0.0123 & -0.0396 & 180 \\
\hline & $(0.0516)$ & $(0.0518)$ & $(0.0463)$ & $(0.0657)$ & {$[1227]$} \\
\hline
\end{tabular}

Notes: Standard errors in round parentheses as indicated in column headers. The sample is composed by 1227 observations (180 studies). All models relating to robustness checks, falsification tests, placebo or appendix have been omitted. Only the main specifications of the studies are included in the sample.

Significance levels $* * * 0.001 * * 0.01 * 0.05$ 
Table B.6: Meta-regression, publication related issues

\begin{tabular}{|c|c|c|c|c|c|c|}
\hline & \multicolumn{2}{|c|}{ H-Index } & \multicolumn{2}{|c|}{ Institutions } & \multicolumn{2}{|c|}{ Published only } \\
\hline & $\begin{array}{l}\text { RE ML } \\
\text { (s.e.) }\end{array}$ & $\begin{array}{c}\text { Studies } \\
\text { [Eff. sizes] }\end{array}$ & $\begin{array}{l}\text { RE ML } \\
\text { (s.e.) }\end{array}$ & $\begin{array}{c}\text { Studies } \\
\text { [Eff. sizes] }\end{array}$ & $\begin{array}{l}\text { RE ML } \\
\text { (s.e.) }\end{array}$ & $\begin{array}{c}\text { Studies } \\
\text { [Eff. sizes] }\end{array}$ \\
\hline \multicolumn{7}{|l|}{ Publication } \\
\hline \multirow[t]{2}{*}{ H-index } & 0.0001 & 176 & 0.0003 & 176 & & \\
\hline & $(0.0002)$ & {$[1834]$} & $(0.0003)$ & {$[1834]$} & & \\
\hline \multirow[t]{2}{*}{ US-UK institution } & & & $0.0711^{*}$ & 103 & & \\
\hline & & & $(0.0355)$ & [1121] & & \\
\hline \multirow[t]{2}{*}{ Feedback } & & & 0.0318 & 31 & & \\
\hline & & & $(0.0599)$ & {$[375]$} & & \\
\hline \multirow[t]{2}{*}{ US-UK inst. $\times$ H-Index } & & & -0.0007 & 103 & & \\
\hline & & & $(0.0005)$ & {$[1121]$} & & \\
\hline \multicolumn{7}{|l|}{ Data structure } \\
\hline \multirow[t]{2}{*}{ Cross-section } & 0.0230 & 76 & 0.0256 & 76 & 0.0423 & 70 \\
\hline & $(0.0250)$ & [533] & $(0.0249)$ & [533] & $(0.0266)$ & [563] \\
\hline \multirow[t]{2}{*}{ Time-series } & 0.1054 & 11 & 0.1351 & 11 & -0.098 & 8 \\
\hline & $(0.0757)$ & [100] & $(0.0762)$ & [100] & $(0.0863)$ & {$[51]$} \\
\hline \multirow[t]{2}{*}{ Panel (avg) } & $0.0308^{*}$ & 60 & $0.0303^{*}$ & 60 & $0.0338^{* *}$ & 53 \\
\hline & $(0.0124)$ & [640] & $(0.0124)$ & [640] & $(0.0128)$ & [554] \\
\hline \multicolumn{7}{|l|}{ Estimation techniques } \\
\hline \multirow[t]{2}{*}{$\mathrm{FE}$} & -0.0178 & 59 & -0.0183 & 59 & $-0.033^{*}$ & 47 \\
\hline & $(0.0156)$ & [640] & $(0.0156)$ & {$[640]$} & $(0.0166)$ & {$[472]$} \\
\hline \multirow[t]{2}{*}{ DPD } & 0.0063 & 20 & 0.0067 & 20 & 0.0124 & 18 \\
\hline & $(0.0200)$ & {$[233]$} & $(0.0200)$ & {$[233]$} & $(0.0206)$ & {$[226]$} \\
\hline \multirow[t]{2}{*}{ Other techniques } & -0.0024 & 50 & -0.0034 & 50 & -0.0085 & 42 \\
\hline & $(0.0163)$ & {$[351]$} & $(0.0163)$ & {$[351]$} & $(0.0168)$ & [293] \\
\hline \multicolumn{7}{|l|}{ Non-linear specifications } \\
\hline \multirow[t]{2}{*}{ Non-linearity } & $-0.0925^{* * *}$ & 23 & $-0.0926^{* * *}$ & 23 & $-0.1111^{* * *}$ & 18 \\
\hline & $(0.0182)$ & {$[172]$} & $(0.0182)$ & [172] & $(0.0217)$ & {$[110]$} \\
\hline \multirow[t]{2}{*}{ Interaction } & -0.0106 & 40 & -0.0101 & 40 & -0.0126 & 34 \\
\hline & $(0.0101)$ & {$[403]$} & $(0.0101)$ & [403] & $(0.0106)$ & {$[355]$} \\
\hline \multirow[t]{2}{*}{ Multiple } & $-0.1098^{* *}$ & 9 & $-0.1128^{* *}$ & 9 & $-0.1725^{* * *}$ & 7 \\
\hline & $(0.0348)$ & [60] & $(0.0348)$ & [60] & $(0.0403)$ & [54] \\
\hline \multicolumn{7}{|l|}{ Dependent variable } \\
\hline \multirow[t]{2}{*}{ Level } & 0.0356 & 12 & 0.0362 & 12 & $0.1018^{*}$ & 6 \\
\hline & $(0.0287)$ & {$[51]$} & $(0.0287)$ & {$[51]$} & $(0.0463)$ & {$[30]$} \\
\hline \multicolumn{7}{|l|}{ Democracy } \\
\hline Polity & 0.0035 & 75 & 0.0039 & 75 & 0.0037 & 63 \\
\hline & $(0.0105)$ & [717] & $(0.0105)$ & [717] & $(0.0108)$ & [594] \\
\hline Dichotomous & -0.0144 & 35 & -0.014 & 35 & -0.0227 & 32 \\
\hline & $(0.0136)$ & {$[307]$} & $(0.0136)$ & {$[307]$} & $(0.0134)$ & {$[325]$} \\
\hline Other proxies & 0.0014 & 24 & 0.0023 & 24 & -0.0038 & 19 \\
\hline & $(0.0123)$ & {$[268]$} & $(0.0123)$ & {$[268]$} & $(0.0123)$ & [168] \\
\hline Control variables & & & & & & \\
\hline Convergence & $0.0300^{*}$ & 141 & $0.0293^{*}$ & 141 & 0.0227 & 126 \\
\hline & $(0.0139)$ & [1538] & $(0.0139)$ & [1538] & $(0.0148)$ & [1406] \\
\hline
\end{tabular}


Table B. 6 - continued from previous page

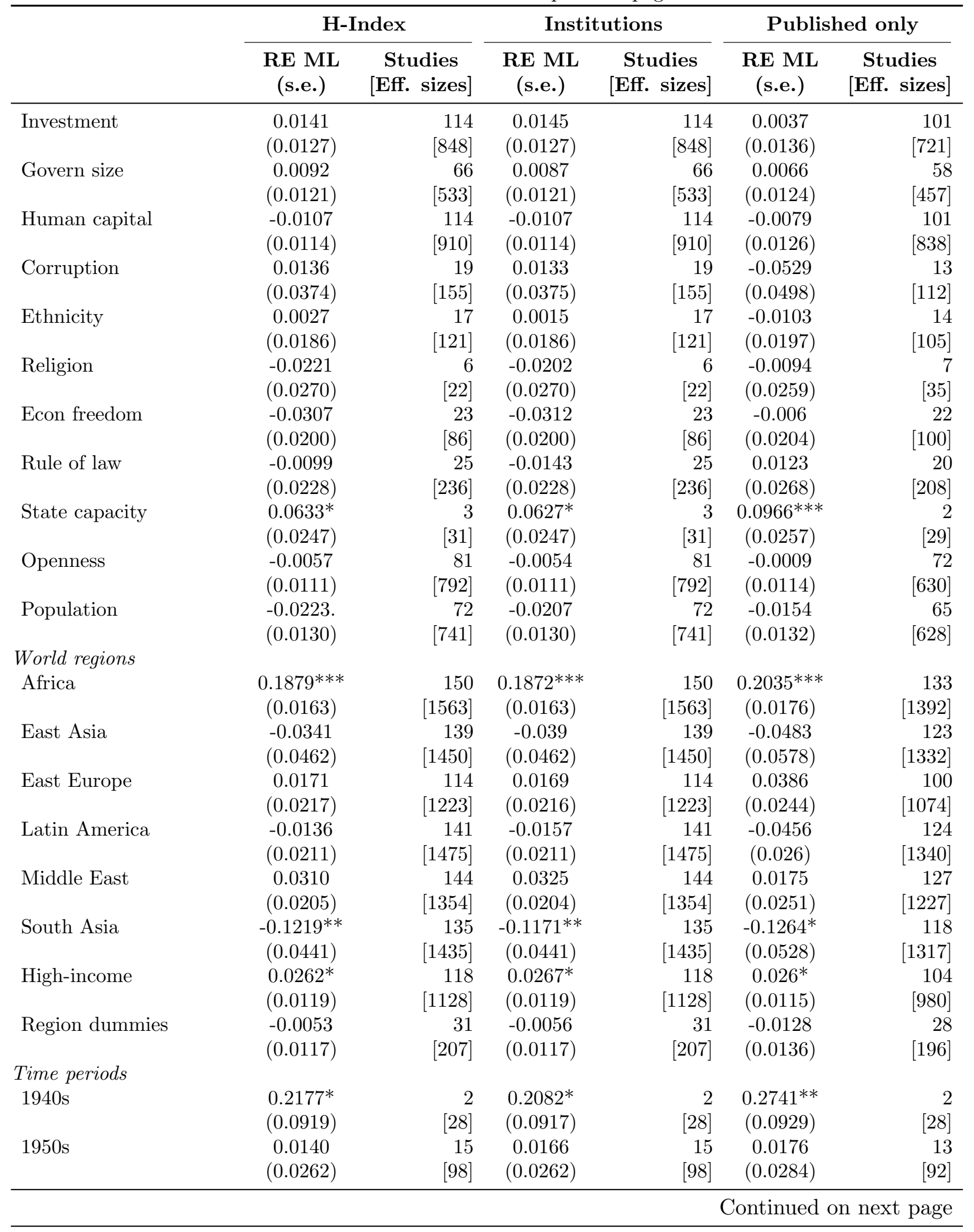


Table B. 6 - continued from previous page

\begin{tabular}{|c|c|c|c|c|c|c|}
\hline & \multicolumn{2}{|c|}{ H-Index } & \multicolumn{2}{|c|}{ Institutions } & \multicolumn{2}{|c|}{ Published only } \\
\hline & $\begin{array}{c}\text { RE ML } \\
\text { (s.e.) }\end{array}$ & $\begin{array}{l}\text { Studies } \\
\text { [Eff. sizes] }\end{array}$ & $\begin{array}{c}\text { RE ML } \\
\text { (s.e.) }\end{array}$ & $\begin{array}{c}\text { Studies } \\
\text { [Eff. sizes] }\end{array}$ & $\begin{array}{c}\text { RE ML } \\
\text { (s.e.) }\end{array}$ & $\begin{array}{c}\text { Studies } \\
\text { [Eff. sizes] }\end{array}$ \\
\hline \multirow[t]{2}{*}{$1960 \mathrm{~s}$} & $-0.0902^{* * *}$ & 86 & $-0.0929 * * *$ & 86 & $-0.08^{* * *}$ & 78 \\
\hline & $(0.018)$ & {$[831]$} & $(0.0180)$ & [831] & $(0.0177)$ & [680] \\
\hline \multirow{2}{*}{$1970 \mathrm{~s}$} & $-0.0374^{*}$ & 130 & $-0.0387^{*}$ & 130 & -0.0304 & 116 \\
\hline & $(0.0158)$ & [1321] & $(0.0158)$ & [1321] & $(0.0168)$ & [1162] \\
\hline \multirow[t]{2}{*}{$1980 \mathrm{~s}$} & $0.0891^{* * *}$ & 146 & $0.0866^{* * *}$ & 146 & $0.1122^{* * *}$ & 128 \\
\hline & $(0.0177)$ & [1553] & $(0.0177)$ & {$[1553]$} & $(0.0182)$ & [1362] \\
\hline \multirow{2}{*}{$1990 \mathrm{~s}$} & 0.0244 & 99 & 0.0307 & 99 & 0.0095 & 83 \\
\hline & $(0.0231)$ & [1305] & $(0.0232)$ & [1305] & $(0.0225)$ & [1069] \\
\hline \multirow[t]{2}{*}{$2000 \mathrm{~s}$} & $-0.0886^{* *}$ & 64 & $-0.0817^{* *}$ & 64 & -0.0627 & 52 \\
\hline & $(0.0309)$ & {$[904]$} & $(0.0312)$ & [904] & $(0.035)$ & [741] \\
\hline \multirow[t]{2}{*}{$2010 \mathrm{~s}$} & 0.0273 & 20 & 0.0376 & 20 & -0.0042 & 15 \\
\hline & $(0.0446)$ & [203] & $(0.0446)$ & [203] & $(0.0479)$ & [83] \\
\hline \multirow[t]{2}{*}{ Constant term } & -0.0570 & 176 & $-0.1092^{*}$ & 176 & -0.0435 & 153 \\
\hline & $(0.0443)$ & [1834] & $(0.0496)$ & [1834] & $(0.0440)$ & [1612] \\
\hline
\end{tabular}

Notes: Random Effects (MultiLevel) MRA. Standard errors in round parentheses. H-Index: RePEc H-Index (10 years) of the journal in which the study has been published; US-UK Institution: $=1$ if at least one of the author is affiliated to a US/UK/Canadian/Australia academic institution; Feedback: $=1$ if the authors acknowledged any feedback from other scholars that already published a study about democracy and growth. The last column refers to a subsample of studies that exclude unpublished works. Significance levels $* * * 0.001 * * 0.01 * 0.05$ 
Table B.7: Meta-regression, publication year

\begin{tabular}{|c|c|c|c|}
\hline & $\begin{array}{c}\text { Full model } \\
\text { RE ML } \\
\text { (s.e.) }\end{array}$ & $\begin{array}{c}\text { No periods } \\
\text { RE ML } \\
\text { (s.e.) }\end{array}$ & $\begin{array}{l}\text { Studies } \\
\text { [Eff. sizes] }\end{array}$ \\
\hline Publication year & $\begin{array}{c}-0.0028 \\
(0.0020)\end{array}$ & $\begin{array}{r}-0.0013 \\
(0.0017)\end{array}$ & $\begin{array}{r}188 \\
{[2047]}\end{array}$ \\
\hline \multicolumn{4}{|l|}{ Data structure } \\
\hline Cross-section & $\begin{array}{c}0.0365 \\
(0.022)\end{array}$ & $\begin{array}{r}0.0290 \\
(0.021)\end{array}$ & $\begin{array}{r}81 \\
{[603]}\end{array}$ \\
\hline Time-series & $\begin{array}{c}0.1205 \\
(0.0695)\end{array}$ & $\begin{array}{c}0.1320 \\
(0.0684)\end{array}$ & $\begin{array}{r}11 \\
{[100]}\end{array}$ \\
\hline Panel (avg) & $\begin{array}{l}0.0300 * * \\
(0.0106)\end{array}$ & $\begin{array}{l}0.0287 * * \\
(0.0106)\end{array}$ & $\begin{array}{r}63 \\
{[663]}\end{array}$ \\
\hline \multicolumn{4}{|c|}{ Estimation techniques } \\
\hline $\mathrm{FE}$ & $\begin{array}{c}-0.0154 \\
(0.0137)\end{array}$ & $\begin{array}{c}-0.0166 \\
(0.0138)\end{array}$ & $\begin{array}{r}67 \\
{[777]}\end{array}$ \\
\hline DPD & $\begin{array}{c}0.0055 \\
(0.0175)\end{array}$ & $\begin{array}{c}0.0082 \\
(0.0176)\end{array}$ & $\begin{array}{r}20 \\
{[233]}\end{array}$ \\
\hline Other techniques & $\begin{array}{c}-0.0010 \\
(0.0144)\end{array}$ & $\begin{array}{c}-0.0045 \\
(0.0143)\end{array}$ & $\begin{array}{r}54 \\
{[370]}\end{array}$ \\
\hline \multicolumn{4}{|c|}{ Non-linear specifications } \\
\hline Non-linearity & $\begin{array}{c}-0.0866 * * * \\
(0.0163)\end{array}$ & $\begin{array}{c}-0.0899 * * * \\
(0.0164)\end{array}$ & $\begin{array}{r}25 \\
{[248]}\end{array}$ \\
\hline Interaction & $\begin{array}{c}-0.0113 \\
(0.009)\end{array}$ & $\begin{array}{c}-0.0103 \\
(0.0091)\end{array}$ & $\begin{array}{r}40 \\
{[403]}\end{array}$ \\
\hline Multiple & $\begin{array}{c}-0.1048 * * * \\
(0.0313)\end{array}$ & $\begin{array}{c}-0.1024 * * \\
(0.0315)\end{array}$ & $\begin{array}{r}10 \\
{[68]}\end{array}$ \\
\hline \multicolumn{4}{|l|}{ Dependent variable } \\
\hline Level & $\begin{array}{c}0.0431 \\
(0.0258)\end{array}$ & $\begin{array}{c}0.0255 \\
(0.0253)\end{array}$ & $\begin{array}{r}13 \\
{[54]}\end{array}$ \\
\hline \multicolumn{4}{|l|}{ Democracy } \\
\hline Polity & $\begin{array}{c}0.0017 \\
(0.0086)\end{array}$ & $\begin{array}{c}-0.0004 \\
(0.0087)\end{array}$ & $\begin{array}{r}80 \\
{[771]}\end{array}$ \\
\hline Dichotomous & $\begin{array}{c}-0.0163 \\
(0.0109)\end{array}$ & $\begin{array}{r}-0.0182 \\
(0.0107)\end{array}$ & $\begin{array}{r}39 \\
{[361]}\end{array}$ \\
\hline Other proxies & $\begin{array}{c}0.0009 \\
(0.0085)\end{array}$ & $\begin{array}{c}-0.0007 \\
(0.0085)\end{array}$ & $\begin{array}{r}28 \\
{[323]}\end{array}$ \\
\hline \multicolumn{4}{|l|}{ Control variables } \\
\hline Convergence & $\begin{array}{c}0.0302 * \\
(0.0123)\end{array}$ & $\begin{array}{r}0.0283 * \\
(0.0124)\end{array}$ & $\begin{array}{r}152 \\
{[1748]}\end{array}$ \\
\hline Investment & $\begin{array}{c}0.0059 \\
(0.0109)\end{array}$ & $\begin{array}{c}0.0055 \\
(0.0108)\end{array}$ & $\begin{array}{r}120 \\
{[920]}\end{array}$ \\
\hline Govern size & $\begin{array}{c}0.0112 \\
(0.0104)\end{array}$ & $\begin{array}{c}0.0081 \\
(0.0105)\end{array}$ & $\begin{array}{r}69 \\
{[550]}\end{array}$ \\
\hline Human capital & $\begin{array}{c}-0.0089 \\
(0.01)\end{array}$ & $\begin{array}{l}-0.01 \\
(0.0101)\end{array}$ & $\begin{array}{r}120 \\
{[991]}\end{array}$ \\
\hline Corruption & 0.0182 & 0.0512 & 20 \\
\hline
\end{tabular}


Table B.7 - continued from previous page

\begin{tabular}{|c|c|c|c|}
\hline & $\begin{array}{c}\text { Full model } \\
\text { RE ML } \\
\text { (s.e.) }\end{array}$ & $\begin{array}{c}\text { No periods } \\
\text { RE ML } \\
\text { (s.e.) }\end{array}$ & $\begin{array}{l}\text { Studies } \\
\text { [Eff. sizes] }\end{array}$ \\
\hline & $(0.0344)$ & $(0.0332)$ & {$[158]$} \\
\hline Ethnicity & $\begin{array}{c}0.0012 \\
(0.0163)\end{array}$ & $\begin{array}{c}-0.0013 \\
(0.0164)\end{array}$ & $\begin{array}{r}18 \\
{[122]}\end{array}$ \\
\hline Religion & $\begin{array}{c}-0.0141 \\
(0.0229)\end{array}$ & $\begin{array}{c}-0.0131 \\
(0.0229)\end{array}$ & $\begin{array}{r}7 \\
{[35]}\end{array}$ \\
\hline Econ freedom & $\begin{array}{c}-0.0187 \\
(0.0172)\end{array}$ & $\begin{array}{c}-0.0044 \\
(0.0171)\end{array}$ & $\begin{array}{r}26 \\
{[115]}\end{array}$ \\
\hline Rule of law & $\begin{array}{c}-0.0072 \\
(0.021)\end{array}$ & $\begin{array}{c}0.0107 \\
(0.0208)\end{array}$ & $\begin{array}{r}26 \\
{[239]}\end{array}$ \\
\hline State capacity & $\begin{array}{l}0.0538 * \\
(0.022)\end{array}$ & $\begin{array}{l}0.0561 * * \\
(0.0205)\end{array}$ & $\begin{array}{r}3 \\
{[31]}\end{array}$ \\
\hline Openness & $\begin{array}{c}-0.0074 \\
(0.0096)\end{array}$ & $\begin{array}{c}-0.0074 \\
(0.0096)\end{array}$ & $\begin{array}{r}86 \\
{[902]}\end{array}$ \\
\hline Population & $\begin{array}{r}-0.0226 * \\
(0.0105)\end{array}$ & $\begin{array}{c}-0.0167 \\
(0.0104)\end{array}$ & $\begin{array}{r}79 \\
{[849]}\end{array}$ \\
\hline World regions & & & \\
\hline Africa & $\begin{array}{l}0.1758 * * * \\
(0.0148)\end{array}$ & $\begin{array}{l}0.1791 * * * \\
(0.0149)\end{array}$ & $\begin{array}{r}161 \\
{[1773]}\end{array}$ \\
\hline East Asia & $\begin{array}{c}-0.033 \\
(0.0432)\end{array}$ & $\begin{array}{c}-0.0370 \\
(0.0431)\end{array}$ & $\begin{array}{r}150 \\
{[1657]}\end{array}$ \\
\hline East Europe & $\begin{array}{c}0.0165 \\
(0.0187)\end{array}$ & $\begin{array}{c}0.0171 \\
(0.0188)\end{array}$ & $\begin{array}{r}125 \\
{[1388]}\end{array}$ \\
\hline Latin America & $\begin{array}{c}-0.0123 \\
(0.0194)\end{array}$ & $\begin{array}{c}-0.0093 \\
(0.0195)\end{array}$ & $\begin{array}{r}152 \\
{[1682]}\end{array}$ \\
\hline Middle East & $\begin{array}{c}0.0300 \\
(0.0182)\end{array}$ & $\begin{array}{c}0.0284 \\
(0.0183)\end{array}$ & $\begin{array}{r}155 \\
{[1561]}\end{array}$ \\
\hline South Asia & $\begin{array}{c}-0.1084 * * \\
(0.0412)\end{array}$ & $\begin{array}{r}-0.1059 * \\
(0.0411)\end{array}$ & $\begin{array}{r}146 \\
{[1642]}\end{array}$ \\
\hline High-income & $\begin{array}{c}0.0244 * * \\
(0.0094)\end{array}$ & $\begin{array}{c}0.0245 * * \\
(0.0095)\end{array}$ & $\begin{array}{r}129 \\
{[1299]}\end{array}$ \\
\hline Region dummies & $\begin{array}{c}-0.0057 \\
(0.0102)\end{array}$ & $\begin{array}{c}-0.0048 \\
(0.0103)\end{array}$ & $\begin{array}{r}33 \\
{[211]}\end{array}$ \\
\hline Time dummies & & & \\
\hline $1940 \mathrm{~s}$ & $\begin{array}{l}0.035 \\
(0.0331)\end{array}$ & -0.0013 & $\begin{array}{r}3 \\
{[34]}\end{array}$ \\
\hline $1950 \mathrm{~s}$ & $\begin{array}{c}-0.0023 \\
(0.0207)\end{array}$ & & $\begin{array}{r}16 \\
{[106]}\end{array}$ \\
\hline $1960 \mathrm{~s}$ & $\begin{array}{c}-0.0623 * * * \\
(0.0149)\end{array}$ & & $\begin{array}{r}95 \\
{[990]}\end{array}$ \\
\hline $1970 \mathrm{~s}$ & $\begin{array}{c}-0.0442 * * \\
(0.0145)\end{array}$ & & $\begin{array}{r}140 \\
{[1525]}\end{array}$ \\
\hline $1980 \mathrm{~s}$ & $\begin{array}{l}0.0843 * * * \\
(0.0164)\end{array}$ & & $\begin{array}{r}157 \\
{[1763]}\end{array}$ \\
\hline $1990 \mathrm{~s}$ & 0.0207 & & 108 \\
\hline \multicolumn{4}{|c|}{ Continued on next page } \\
\hline
\end{tabular}


Table B.7 - continued from previous page

\begin{tabular}{lccrr}
\hline & Full model & No periods & \\
\cline { 2 - 2 } & $\begin{array}{c}\text { RE ML } \\
\text { (s.e.) }\end{array}$ & & $\begin{array}{c}\text { RE ML } \\
\text { (s.e.) }\end{array}$ & $\begin{array}{c}\text { Studies } \\
\text { [Eff. sizes] }\end{array}$ \\
\hline \multirow{2}{*}{$2000 \mathrm{~s}$} & $(0.0194)$ & & {$[1458]$} \\
& -0.0323 & & 70 \\
& $(0.0196)$ & & {$[1019]$} \\
Constant term & 0.0322 & & 22 \\
& $(0.0397)$ & & {$[281]$} \\
& 5.5056 & 2.4532 & 188 \\
& $(4.0311)$ & $(3.3723)$ & {$[2047]$} \\
\hline
\end{tabular}

Notes: Random Effects (MultiLevel) MRA. Standard errors in round parentheses as indicated in column headers. The sample is composed by 2047 observations (188 studies). Both model specifications include the publication year of the study as a control variable.

Significance levels $* * * 0.001 * * 0.01 * 0.05$ 
Table B.8: Meta-regression, full sample, effect of controlling for endogeneity

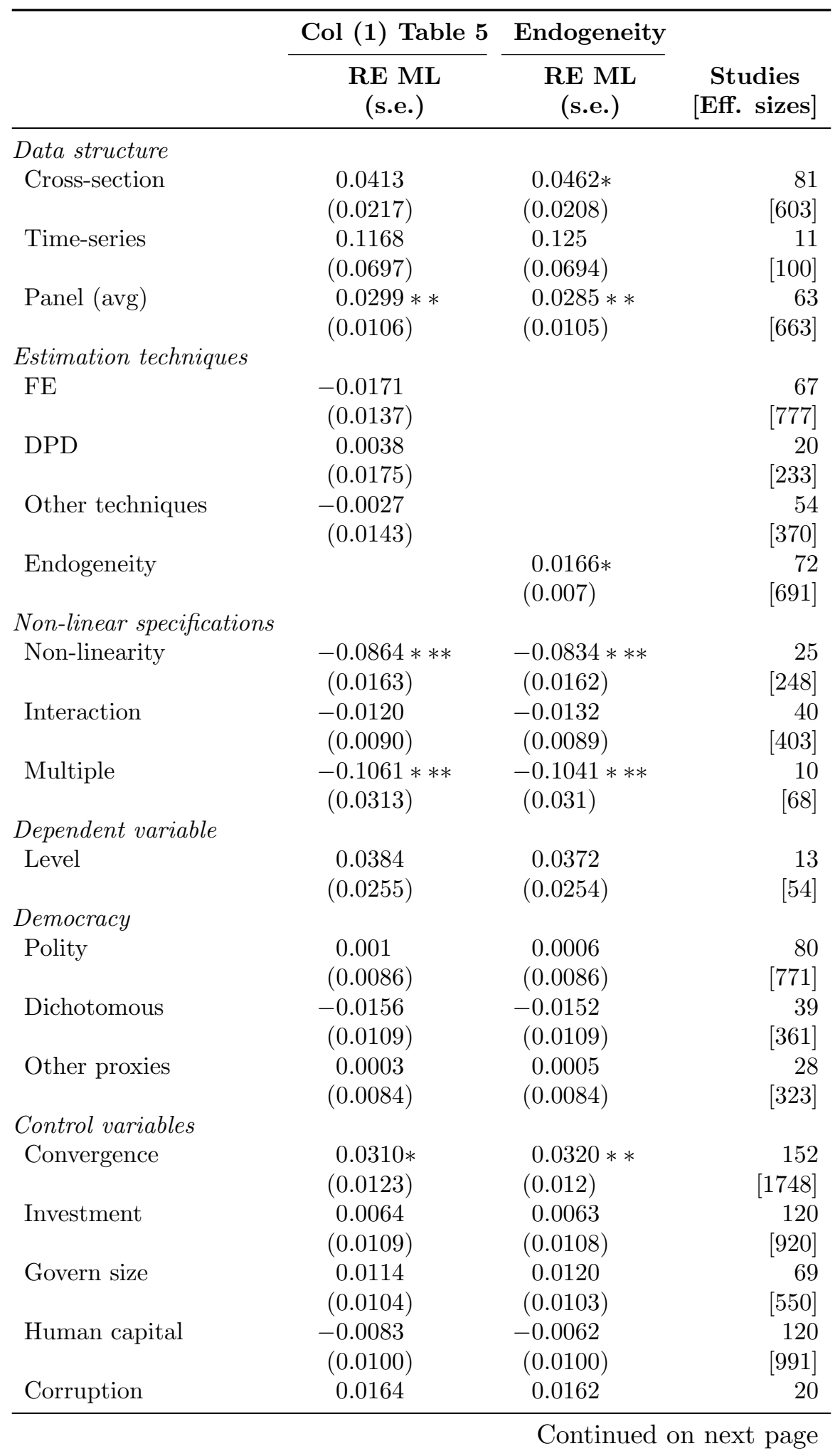


Table B. 8 - continued from previous page

\begin{tabular}{|c|c|c|c|}
\hline & Col (1) Table 5 & Endogeneity & \\
\hline & $\begin{array}{c}\text { RE ML } \\
\text { (s.e.) }\end{array}$ & $\begin{array}{c}\text { RE ML } \\
\text { (s.e.) }\end{array}$ & $\begin{array}{l}\text { Studies } \\
{[\text { Eff. sizes] }}\end{array}$ \\
\hline & $(0.0344)$ & $(0.0345)$ & [158] \\
\hline Ethnicity & 0.0006 & 0.0103 & 18 \\
\hline & $(0.0163)$ & $(0.0145)$ & [122] \\
\hline Religion & -0.0152 & -0.0081 & 7 \\
\hline & $(0.0229)$ & $(0.0228)$ & {$[35]$} \\
\hline Econ freedom & -0.0180 & -0.0201 & 26 \\
\hline & $(0.0172)$ & $(0.0170)$ & [115] \\
\hline Rule of law & -0.0066 & -0.0060 & 26 \\
\hline & $(0.021)$ & $(0.0209)$ & [239] \\
\hline State capacity & $0.0558 *$ & $0.0544 *$ & 3 \\
\hline & $(0.0220)$ & $(0.0219)$ & {$[31]$} \\
\hline Openness & -0.0079 & -0.0120 & 86 \\
\hline & $(0.0095)$ & $(0.0095)$ & [902] \\
\hline Population & $-0.0239 *$ & $-0.0248 *$ & 79 \\
\hline & $(0.0104)$ & $(0.0102)$ & [849] \\
\hline World regions & & & \\
\hline Africa & $0.1757 * * *$ & $0.1754 * * *$ & 161 \\
\hline & $(0.0148)$ & $(0.0148)$ & [1773] \\
\hline East Asia & -0.0289 & -0.0260 & 150 \\
\hline & $(0.0431)$ & $(0.0432)$ & [1657] \\
\hline East Europe & 0.0148 & 0.0152 & 125 \\
\hline & $(0.0187)$ & $(0.0187)$ & [1388] \\
\hline Latin America & -0.0120 & -0.0115 & 152 \\
\hline & $(0.0193)$ & $(0.0193)$ & [1682] \\
\hline Middle East & 0.0310 & 0.0308 & 155 \\
\hline & $(0.0182)$ & $(0.0182)$ & [1561] \\
\hline South Asia & $-0.1117 * *$ & $-0.1135 * *$ & 146 \\
\hline & $(0.0412)$ & $(0.0413)$ & [1642] \\
\hline High-income & $0.0241 *$ & $0.0248 * *$ & 129 \\
\hline & $(0.0094)$ & $(0.0094)$ & [1299] \\
\hline Region dummies & -0.0062 & -0.0028 & 33 \\
\hline & $(0.0102)$ & $(0.0099)$ & [211] \\
\hline Time periods & & & \\
\hline $1940 \mathrm{~s}$ & 0.0382 & 0.0386 & 3 \\
\hline & $(0.033)$ & $(0.0329)$ & [34] \\
\hline $1950 \mathrm{~s}$ & -0.0050 & -0.0073 & 16 \\
\hline & $(0.0206)$ & $(0.0206)$ & [106] \\
\hline $1960 \mathrm{~s}$ & $-0.0605 * * *$ & $-0.0612 * * *$ & 95 \\
\hline & $(0.0148)$ & $(0.0148)$ & [990] \\
\hline $1970 \mathrm{~s}$ & $-0.0424 * *$ & $-0.0430 * *$ & 140 \\
\hline & $(0.0144)$ & $(0.0144)$ & [1525] \\
\hline $1980 \mathrm{~s}$ & $0.0863 * * *$ & $0.0856 * * *$ & 157 \\
\hline & $(0.0164)$ & $(0.0163)$ & [1763] \\
\hline $1990 \mathrm{~s}$ & 0.0136 & 0.0124 & 108 \\
\hline
\end{tabular}


Table B.8 - continued from previous page

\begin{tabular}{lcccr}
\hline & Col (1) Table 5 & & Endogeneity & \\
\cline { 2 - 2 } & $\begin{array}{c}\text { RE ML } \\
\text { (s.e.) }\end{array}$ & & $\begin{array}{c}\text { RE ML } \\
\text { (s.e.) }\end{array}$ & $\begin{array}{c}\text { Studies } \\
\text { [Eff. sizes] }\end{array}$ \\
\hline \multirow{2}{*}{$2000 \mathrm{~s}$} & $(0.0187)$ & & $(0.0187)$ & {$[1458]$} \\
& $-0.0409 *$ & & $-0.0442 *$ & 70 \\
$2010 \mathrm{~s}$ & $(0.0185)$ & & $(0.0182)$ & {$[1019]$} \\
& 0.0170 & & 0.0146 & 22 \\
Constant term & $(0.0383)$ & & $(0.0384)$ & {$[281]$} \\
& -0.0674 & & $0.0786 *$ & 188 \\
& $(0.0366)$ & $(0.0353)$ & {$[2047]$} \\
\hline
\end{tabular}

Notes: Random Effects (MultiLevel) MRA. Standard errors in round parentheses. The sample is composed by 2047 observations (188 studies). Endogeneity $=1$ if the study account for potential endogeneity.

Significance levels $* * * 0.001 * * 0.01 * 0.05$ 


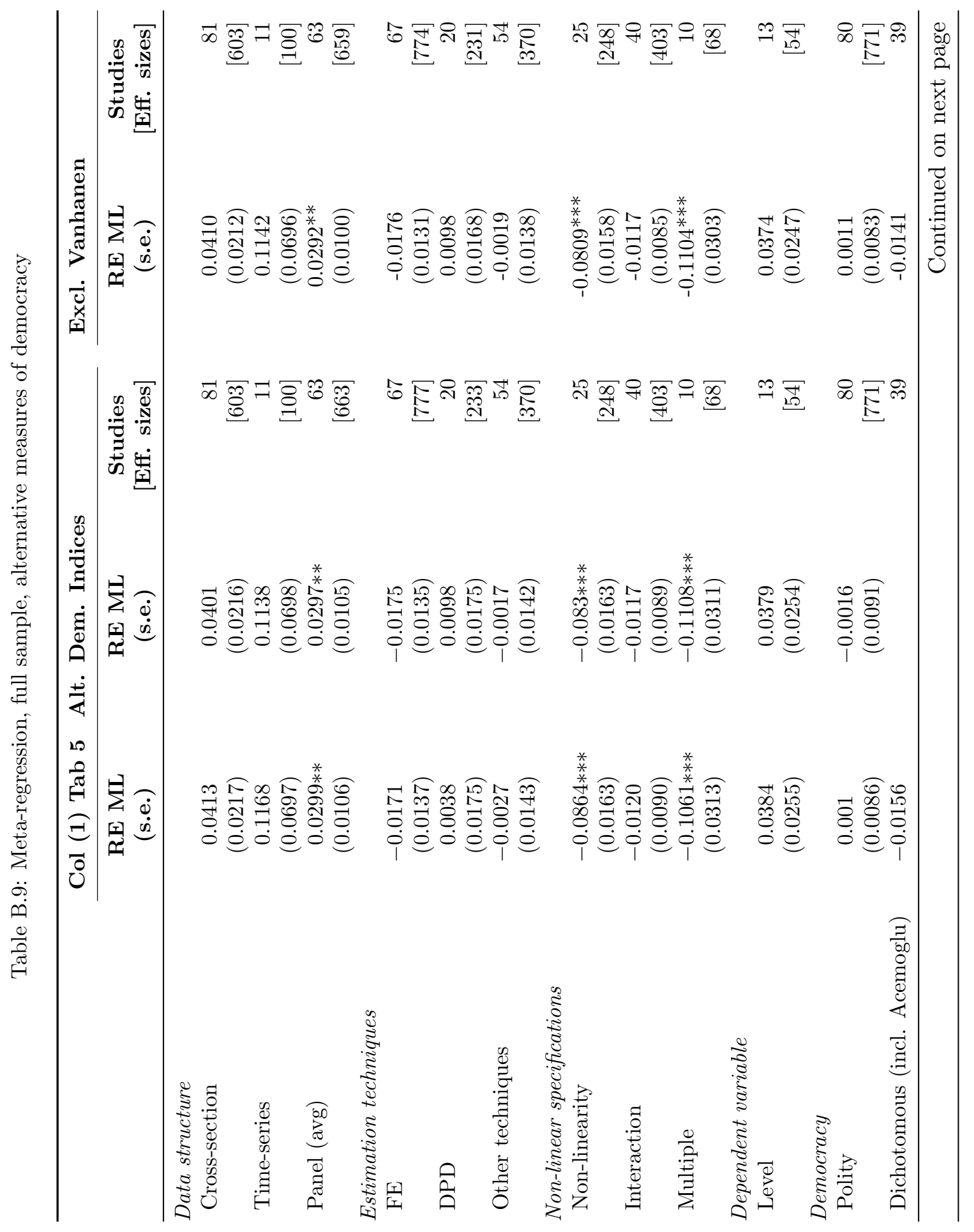




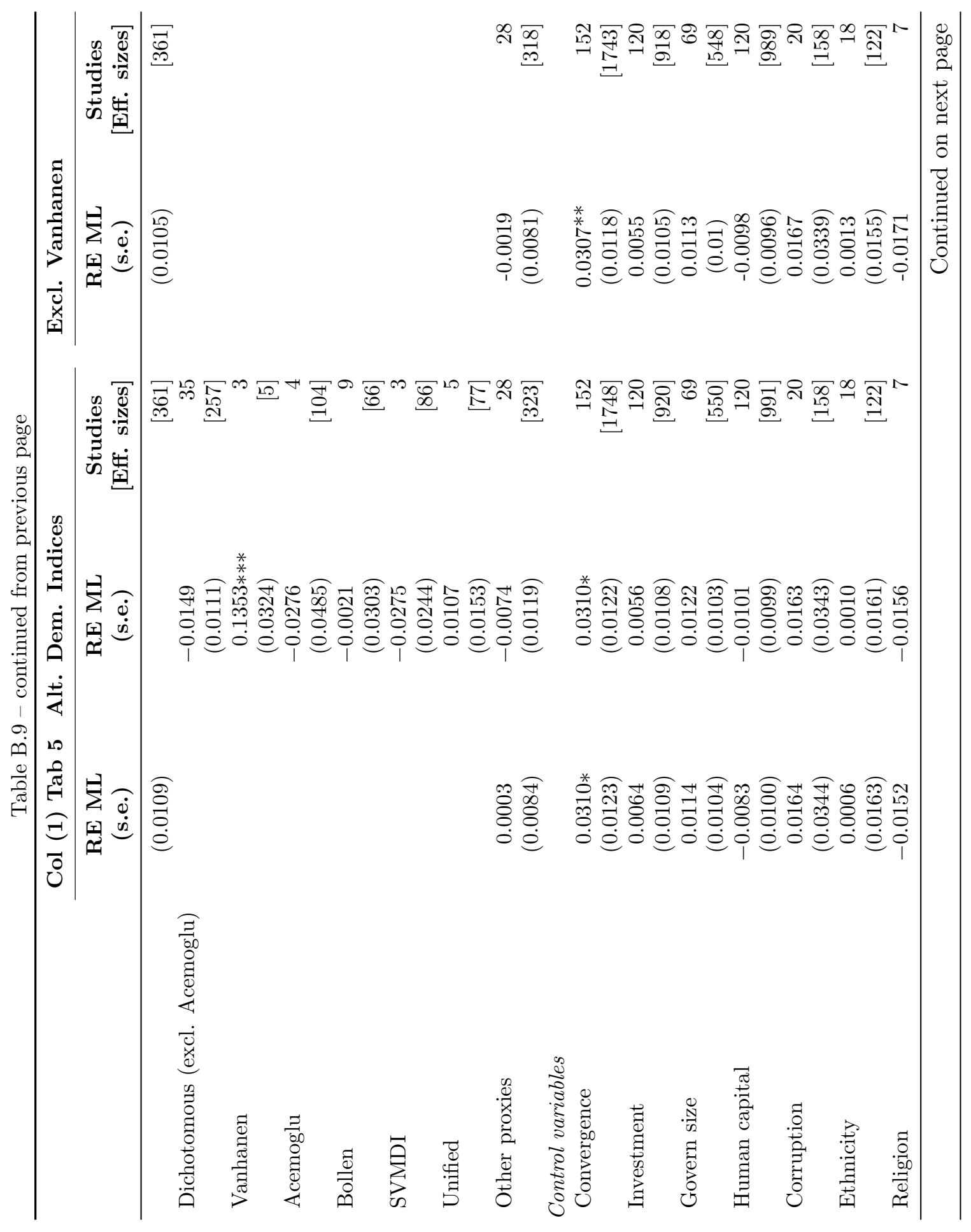




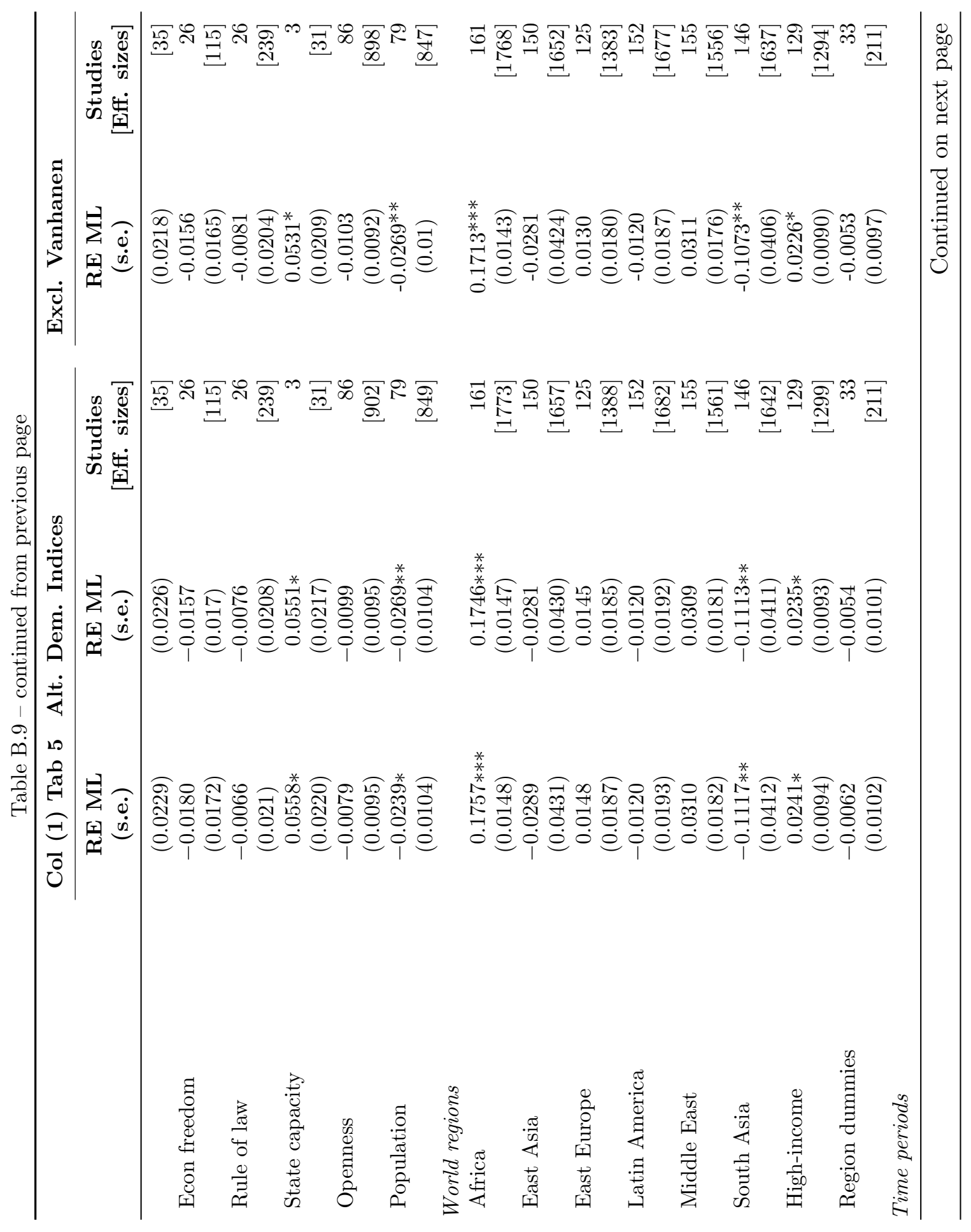




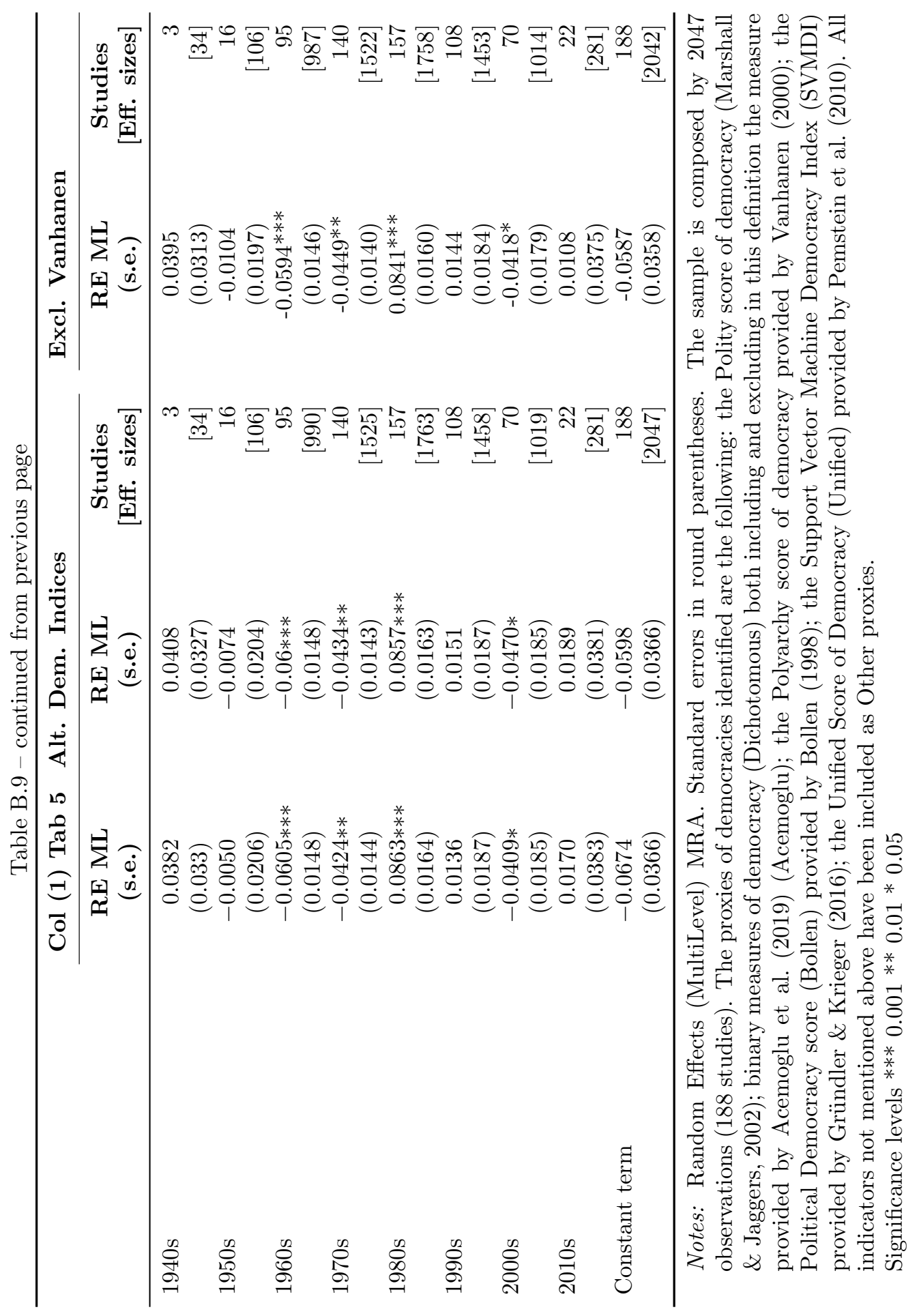


Table B.10: Meta-regression, excluding zero-order correlations

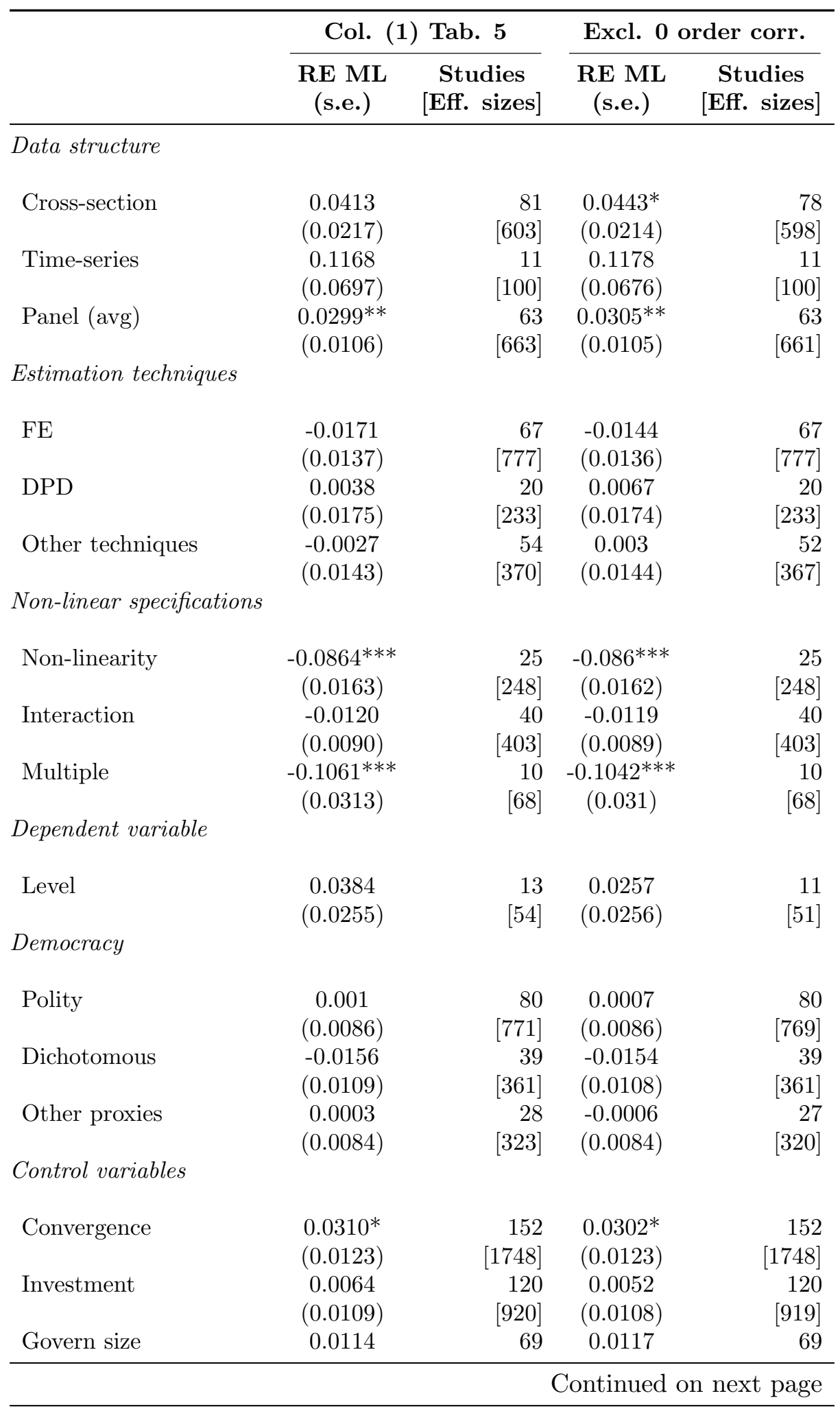


Table B.10 - continued from previous page

\begin{tabular}{|c|c|c|c|c|}
\hline & Col. (1 & Tab. 5 & Excl. 0 & rder corr. \\
\hline & $\begin{array}{c}\text { RE ML } \\
\text { (s.e.) }\end{array}$ & $\begin{array}{c}\text { Studies } \\
{[\text { Eff. sizes] }}\end{array}$ & $\begin{array}{c}\text { RE ML } \\
\text { (s.e.) }\end{array}$ & $\begin{array}{l}\text { Studies } \\
\text { [Eff. sizes] }\end{array}$ \\
\hline & $(0.0104)$ & {$[550]$} & $(0.0103)$ & {$[550]$} \\
\hline Human capital & -0.0083 & 120 & -0.0078 & 120 \\
\hline & $(0.0100)$ & [991] & $(0.0099)$ & [991] \\
\hline Corruption & 0.0164 & 20 & 0.018 & 20 \\
\hline & $(0.0344)$ & [158] & $(0.0339)$ & {$[158]$} \\
\hline Ethnicity & 0.0006 & 18 & 0.0019 & 18 \\
\hline & $(0.0163)$ & {$[122]$} & $(0.0162)$ & {$[122]$} \\
\hline Religion & -0.0152 & 7 & -0.0149 & 7 \\
\hline & $(0.0229)$ & {$[35]$} & $(0.0227)$ & [35] \\
\hline Econ freedom & -0.0180 & 26 & -0.0177 & 26 \\
\hline & $(0.0172)$ & [115] & $(0.017)$ & [115] \\
\hline Rule of law & -0.0066 & 26 & -0.005 & 26 \\
\hline & $(0.021)$ & [239] & $(0.0208)$ & [239] \\
\hline State capacity & $0.0558^{*}$ & 3 & $0.0562^{*}$ & 3 \\
\hline & $(0.0220)$ & [31] & $(0.0218)$ & [31] \\
\hline Openness & -0.0079 & 86 & -0.0078 & 86 \\
\hline & $(0.0095)$ & [902] & $(0.0095)$ & [902] \\
\hline Population & $-0.0239^{*}$ & 79 & $-0.0233^{*}$ & 79 \\
\hline & $(0.0104)$ & [849] & $(0.0103)$ & [849] \\
\hline World regions & & & & \\
\hline Africa & $0.1757^{* * *}$ & 161 & $0.1723^{* * *}$ & 159 \\
\hline & $(0.0148)$ & {$[1773]$} & $(0.0147)$ & [1767] \\
\hline East Asia & -0.0289 & 150 & -0.0247 & 148 \\
\hline & $(0.0431)$ & [1657] & $(0.0424)$ & [1653] \\
\hline East Europe & 0.0148 & 125 & 0.0189 & 122 \\
\hline & $(0.0187)$ & [1388] & $(0.0185)$ & [1384] \\
\hline Latin America & -0.0120 & 152 & -0.0123 & 150 \\
\hline & $(0.0193)$ & {$[1682]$} & $(0.0192)$ & [1678] \\
\hline Middle East & 0.0310 & 155 & 0.0282 & 153 \\
\hline & $(0.0182)$ & [1561] & $(0.0181)$ & [1557] \\
\hline South Asia & $-0.1117^{* *}$ & 146 & $-0.1164^{* *}$ & 144 \\
\hline & $(0.0412)$ & [1642] & $(0.0405)$ & [1638] \\
\hline High-income & $0.0241^{*}$ & 129 & $0.0227^{*}$ & 127 \\
\hline & $(0.0094)$ & [1299] & $(0.0094)$ & [1295] \\
\hline Region dummies & -0.0062 & 33 & -0.0059 & 33 \\
\hline & $(0.0102)$ & [211] & $(0.0101)$ & [211] \\
\hline Time periods & & & & \\
\hline $1940 \mathrm{~s}$ & 0.0382 & 3 & 0.0353 & 3 \\
\hline & $(0.033)$ & {$[34]$} & $(0.0327)$ & {$[34]$} \\
\hline $1950 \mathrm{~s}$ & -0.0050 & 16 & -0.004 & 16 \\
\hline & $(0.0206)$ & {$[106]$} & $(0.0204)$ & {$[106]$} \\
\hline $1960 \mathrm{~s}$ & $-0.0605^{* * *}$ & 95 & $-0.0592^{* * *}$ & 95 \\
\hline & & & ontinued & next page \\
\hline
\end{tabular}


Table B.10 - continued from previous page

\begin{tabular}{|c|c|c|c|c|}
\hline & \multicolumn{2}{|c|}{ Col. (1) Tab. 5} & \multicolumn{2}{|c|}{ Excl. 0 order corr. } \\
\hline & $\begin{array}{c}\text { RE ML } \\
\text { (s.e.) }\end{array}$ & $\begin{array}{c}\text { Studies } \\
\text { [Eff. sizes] }\end{array}$ & $\begin{array}{c}\text { RE ML } \\
\text { (s.e.) }\end{array}$ & $\begin{array}{l}\text { Studies } \\
\text { [Eff. sizes] }\end{array}$ \\
\hline \multirow{3}{*}{$1970 \mathrm{~s}$} & $(0.0148)$ & {$[990]$} & $(0.0147)$ & [987] \\
\hline & $-0.0424^{* *}$ & 140 & $-0.0409^{* *}$ & 140 \\
\hline & $(0.0144)$ & [1525] & $(0.0144)$ & [1522] \\
\hline \multirow[t]{2}{*}{ 1980s } & $0.0863^{* * *}$ & 157 & $0.0838^{* * *}$ & 156 \\
\hline & $(0.0164)$ & [1763] & $(0.0163)$ & [1759] \\
\hline \multirow[t]{2}{*}{$1990 \mathrm{~s}$} & 0.0136 & 108 & 0.0154 & 108 \\
\hline & $(0.0187)$ & [1458] & $(0.0185)$ & [1456] \\
\hline \multirow[t]{2}{*}{$2000 \mathrm{~s}$} & $-0.0409^{*}$ & 70 & $-0.0409^{*}$ & 68 \\
\hline & $(0.0185)$ & [1019] & $(0.0184)$ & [1014] \\
\hline \multirow[t]{2}{*}{$2010 \mathrm{~s}$} & 0.0170 & 22 & 0.0228 & 22 \\
\hline & $(0.0383)$ & [281] & $(0.0373)$ & [279] \\
\hline \multirow[t]{2}{*}{ Constant term } & -0.0674 & 188 & -0.0696 & 185 \\
\hline & $(0.0366)$ & [2047] & $(0.0363)$ & [2040] \\
\hline
\end{tabular}

Notes: Random Effects (MultiLevel) MRA. Standard errors in round parentheses. The analysis excludes all models based on zero-order correlations between democracy and growth. The sample is composed by 2040 observations (185 studies).

Significance levels $* * * 0.001 * * 0.01 * 0.05$ 
Table B.11: Meta-regression, excluding models with Level GDP as dependent variable

\begin{tabular}{|c|c|c|c|c|}
\hline & \multicolumn{2}{|c|}{ Col. (1) Tab. 5} & \multicolumn{2}{|c|}{ Excluding Level $==1$} \\
\hline & $\begin{array}{l}\text { RE ML } \\
\text { (s.e.) }\end{array}$ & $\begin{array}{c}\text { Studies } \\
\text { [Eff. sizes] }\end{array}$ & $\begin{array}{c}\text { RE ML } \\
\text { (s.e.) }\end{array}$ & $\begin{array}{l}\text { Studies } \\
\text { [Eff. sizes] }\end{array}$ \\
\hline \multicolumn{5}{|l|}{ Data structure } \\
\hline Cross-section & $\begin{array}{c}0.0413 \\
(0.0217)\end{array}$ & $\begin{array}{r}81 \\
{[603]}\end{array}$ & $\begin{array}{c}0.0426 \\
(0.0233)\end{array}$ & $\begin{array}{r}70 \\
{[603]}\end{array}$ \\
\hline Time-series & $\begin{array}{c}0.1168 \\
(0.0697)\end{array}$ & $\begin{array}{r}11 \\
{[100]}\end{array}$ & $\begin{array}{l}0.1800^{*} \\
(0.0710)\end{array}$ & $\begin{array}{r}8 \\
8 \\
{[100]}\end{array}$ \\
\hline Panel (avg) & $\begin{array}{c}0.0299^{* *} \\
(0.0106)\end{array}$ & $\begin{array}{r}63 \\
{[663]}\end{array}$ & $\begin{array}{c}0.0313^{* *} \\
(0.0106)\end{array}$ & $\begin{array}{r}53 \\
{[663]}\end{array}$ \\
\hline \multicolumn{5}{|c|}{ Estimation techniques } \\
\hline $\mathrm{FE}$ & $\begin{array}{l}-0.0171 \\
(0.0137)\end{array}$ & $\begin{array}{r}67 \\
{[777]}\end{array}$ & $\begin{array}{l}-0.0160 \\
(0.0138)\end{array}$ & $\begin{array}{r}47 \\
{[777]}\end{array}$ \\
\hline DPD & $\begin{array}{c}0.0038 \\
(0.0175)\end{array}$ & $\begin{array}{r}20 \\
{[233]}\end{array}$ & $\begin{array}{c}0.0104 \\
(0.0175)\end{array}$ & $\begin{array}{r}18 \\
{[233]}\end{array}$ \\
\hline Other est. tech. & $\begin{array}{l}-0.0027 \\
(0.0143)\end{array}$ & $\begin{array}{r}54 \\
{[370]}\end{array}$ & $\begin{array}{l}-0.0010 \\
(0.0147)\end{array}$ & $\begin{array}{r}42 \\
{[370]}\end{array}$ \\
\hline \multicolumn{5}{|c|}{ Non-linear specifications } \\
\hline Non-linearity & $\begin{array}{c}-0.0864^{* * *} \\
(0.0163)\end{array}$ & $\begin{array}{r}25 \\
{[248]}\end{array}$ & $\begin{array}{c}-0.0852^{* * *} \\
(0.0163)\end{array}$ & $\begin{array}{r}18 \\
{[248]}\end{array}$ \\
\hline Interaction & $\begin{array}{l}-0.0120 \\
(0.0090)\end{array}$ & $\begin{array}{r}40 \\
{[403]}\end{array}$ & $\begin{array}{l}-0.0112 \\
(0.0091)\end{array}$ & $\begin{array}{r}34 \\
{[403]}\end{array}$ \\
\hline Multiple & $\begin{array}{c}-0.1061^{* * *} \\
(0.0313)\end{array}$ & $\begin{array}{r}10 \\
{[68]}\end{array}$ & $\begin{array}{c}-0.1054^{* * *} \\
(0.0311)\end{array}$ & $\begin{array}{r}7 \\
{[68]}\end{array}$ \\
\hline \multicolumn{5}{|l|}{ Democracy } \\
\hline Polity & $\begin{array}{c}0.001 \\
(0.0086)\end{array}$ & $\begin{array}{r}80 \\
{[771]}\end{array}$ & $\begin{array}{c}0.0007 \\
(0.0086)\end{array}$ & $\begin{array}{r}63 \\
{[771]}\end{array}$ \\
\hline Dichotomous & $\begin{array}{l}-0.0156 \\
(0.0109)\end{array}$ & $\begin{array}{r}39 \\
{[361]}\end{array}$ & $\begin{array}{l}-0.0166 \\
(0.0109)\end{array}$ & $\begin{array}{r}32 \\
{[361]}\end{array}$ \\
\hline Other & $\begin{array}{c}0.0003 \\
(0.0084)\end{array}$ & $\begin{array}{r}28 \\
{[323]}\end{array}$ & $\begin{array}{l}-0.0004 \\
(0.0084)\end{array}$ & $\begin{array}{r}19 \\
{[323]}\end{array}$ \\
\hline \multicolumn{5}{|l|}{ Control variables } \\
\hline Convergence & $\begin{array}{l}0.0310^{*} \\
(0.0123)\end{array}$ & $\begin{array}{r}152 \\
{[1748]}\end{array}$ & $\begin{array}{l}0.0309^{*} \\
(0.0125)\end{array}$ & $\begin{array}{r}126 \\
{[1748]}\end{array}$ \\
\hline Investment & $\begin{array}{c}0.0064 \\
(0.0109)\end{array}$ & $\begin{array}{r}120 \\
{[920]}\end{array}$ & $\begin{array}{c}0.0061 \\
(0.0109)\end{array}$ & $\begin{array}{r}101 \\
{[920]}\end{array}$ \\
\hline Govern size & $\begin{array}{c}0.0114 \\
(0.0104)\end{array}$ & $\begin{array}{r}69 \\
{[550]}\end{array}$ & $\begin{array}{c}0.0123 \\
(0.0104)\end{array}$ & $\begin{array}{r}58 \\
{[550]}\end{array}$ \\
\hline Human capital & $\begin{array}{l}-0.0083 \\
(0.0100)\end{array}$ & $\begin{array}{r}120 \\
{[991]}\end{array}$ & $\begin{array}{l}-0.0077 \\
(0.0100)\end{array}$ & $\begin{array}{r}101 \\
{[991]}\end{array}$ \\
\hline Corruption & $\begin{array}{c}0.0164 \\
(0.0344)\end{array}$ & $\begin{array}{r}20 \\
{[158]}\end{array}$ & $\begin{array}{c}0.0352 \\
(0.0345)\end{array}$ & $\begin{array}{r}13 \\
{[158]}\end{array}$ \\
\hline Ethnicity & $\begin{array}{c}0.0006 \\
(0.0163)\end{array}$ & $\begin{array}{r}18 \\
{[122]}\end{array}$ & $\begin{array}{l}-0.0016 \\
(0.0163)\end{array}$ & $\begin{array}{r}14 \\
{[122]}\end{array}$ \\
\hline Religion & $\begin{array}{l}-0.0152 \\
(0.0229)\end{array}$ & $\begin{array}{r}7 \\
{[35]}\end{array}$ & $\begin{array}{l}-0.0132 \\
(0.0234)\end{array}$ & $\begin{array}{r}7 \\
{[35]}\end{array}$ \\
\hline
\end{tabular}


Table B.11 - continued from previous page

\begin{tabular}{|c|c|c|c|c|}
\hline & \multicolumn{2}{|c|}{ Col. (1) Tab. 5} & \multicolumn{2}{|c|}{ Excluding Level $==1$} \\
\hline & $\begin{array}{c}\text { RE ML } \\
\text { (s.e.) }\end{array}$ & $\begin{array}{c}\text { Studies } \\
\text { [Eff. sizes] }\end{array}$ & $\begin{array}{c}\text { RE ML } \\
\text { (s.e.) }\end{array}$ & $\begin{array}{c}\text { Studies } \\
\text { [Eff. sizes] }\end{array}$ \\
\hline \multirow{2}{*}{ Econ freedom } & -0.0180 & 26 & -0.0193 & 22 \\
\hline & $(0.0172)$ & [115] & $(0.0171)$ & [115] \\
\hline \multirow{2}{*}{ Rule of law } & -0.0066 & 26 & -0.0056 & 20 \\
\hline & $(0.021)$ & [239] & $(0.0209)$ & [239] \\
\hline \multirow[t]{2}{*}{ State capacity } & $0.0558^{*}$ & 3 & $0.0651^{* *}$ & 2 \\
\hline & $(0.0220)$ & [31] & $(0.0219)$ & [31] \\
\hline \multirow[t]{2}{*}{ Openness } & -0.0079 & 86 & -0.0090 & 72 \\
\hline & $(0.0095)$ & [902] & $(0.0096)$ & [902] \\
\hline \multirow[t]{2}{*}{ Population } & $-0.0239^{*}$ & 79 & $-0.0210^{*}$ & 65 \\
\hline & $(0.0104)$ & [849] & $(0.0104)$ & [849] \\
\hline \multicolumn{5}{|l|}{ World regions } \\
\hline \multirow[t]{2}{*}{ Africa } & $0.1757^{* * *}$ & 161 & $0.1753^{* * *}$ & 133 \\
\hline & $(0.0148)$ & [1773] & $(0.0149)$ & [1773] \\
\hline \multirow[t]{2}{*}{ East Asia } & -0.0289 & 150 & -0.0274 & 123 \\
\hline & $(0.0431)$ & [1657] & $(0.0427)$ & [1657] \\
\hline \multirow[t]{2}{*}{ East Europe } & 0.0148 & 125 & 0.0085 & 100 \\
\hline & $(0.0187)$ & [1388] & $(0.0188)$ & [1388] \\
\hline \multirow[t]{2}{*}{ Latin America } & -0.0120 & 152 & -0.0123 & 124 \\
\hline & $(0.0193)$ & [1682] & $(0.0199)$ & [1682] \\
\hline \multirow[t]{2}{*}{ Middle East } & 0.0310 & 155 & $0.046^{*}$ & 127 \\
\hline & $(0.0182)$ & [1561] & $(0.0187)$ & [1561] \\
\hline \multirow[t]{2}{*}{ South Asia } & $-0.1117^{* *}$ & 146 & $-0.1277^{* *}$ & 118 \\
\hline & $(0.0412)$ & [1642] & $(0.0406)$ & [1642] \\
\hline \multirow[t]{2}{*}{ High-income } & $0.0241^{*}$ & 129 & $0.0228^{*}$ & 104 \\
\hline & $(0.0094)$ & [1299] & $(0.0094)$ & [1299] \\
\hline \multirow[t]{2}{*}{ Region dummies } & -0.0062 & 33 & -0.0046 & 28 \\
\hline & $(0.0102)$ & [211] & $(0.0102)$ & [211] \\
\hline \multicolumn{5}{|l|}{ Time periods } \\
\hline \multirow[t]{2}{*}{$1940 \mathrm{~s}$} & 0.0382 & 3 & 0.0336 & 2 \\
\hline & $(0.033)$ & [34] & $(0.0328)$ & [34] \\
\hline \multirow[t]{2}{*}{$1950 \mathrm{~s}$} & -0.0050 & 16 & -0.0016 & 13 \\
\hline & $(0.0206)$ & [106] & $(0.0205)$ & {$[106]$} \\
\hline \multirow[t]{2}{*}{$1960 \mathrm{~s}$} & $-0.0605^{* * *}$ & 95 & $-0.0549 * * *$ & 78 \\
\hline & $(0.0148)$ & [990] & $(0.0147)$ & [990] \\
\hline \multirow[t]{2}{*}{$1970 \mathrm{~s}$} & $-0.0424^{* *}$ & 140 & $-0.0381^{* *}$ & 116 \\
\hline & $(0.0144)$ & [1525] & $(0.0144)$ & [1525] \\
\hline \multirow[t]{2}{*}{$1980 \mathrm{~s}$} & $0.0863^{* * *}$ & 157 & $0.1034^{* * *}$ & 128 \\
\hline & $(0.0164)$ & [1763] & $(0.0171)$ & [1763] \\
\hline \multirow[t]{2}{*}{$1990 \mathrm{~s}$} & 0.0136 & 108 & 0.0069 & 83 \\
\hline & $(0.0187)$ & [1458] & $(0.0189)$ & {$[1458]$} \\
\hline $2000 \mathrm{~s}$ & $-0.0409^{*}$ & 70 & -0.0200 & 52 \\
\hline & $(0.0185)$ & [1019] & $(0.0195)$ & [1019] \\
\hline $2010 \mathrm{~s}$ & 0.0170 & 22 & 0.0118 & 15 \\
\hline & $(0.0383)$ & [281] & $(0.0381)$ & [281] \\
\hline & & & Jontinued & next page \\
\hline
\end{tabular}


Table B.11 - continued from previous page

\begin{tabular}{lcrrrr}
\hline & \multicolumn{2}{c}{ Col. (1) Tab. 5} & & \multicolumn{2}{c}{ Excluding Level ==1 } \\
\cline { 2 - 3 } & $\begin{array}{c}\text { RE ML } \\
\text { (s.e.) }\end{array}$ & $\begin{array}{c}\text { Studies } \\
\text { [Eff. sizes] }\end{array}$ & & $\begin{array}{c}\text { RE ML } \\
\text { (s.e.) }\end{array}$ & $\begin{array}{c}\text { Studies } \\
\text { [Eff. sizes] }\end{array}$ \\
\hline Constant term & -0.0674 & 188 & & $-0.0949^{*}$ & 181 \\
& $(0.0366)$ & {$[2047]$} & & $(0.0369)$ & {$[1993]$} \\
\hline
\end{tabular}

Notes: Random Effects (MultiLevel) MRA. Standard errors in round parentheses. The sample is composed by 2047 observations (188 studies) for the main model; 1993 observations (181 studies) for the model excluding Level $==1$.

Significance levels $* * * 0.001 * * 0.01 * 0.05$ 
Appendix C. Further descriptives 
Table C.1: Democracy, human capital, and growth: t-statistics

\begin{tabular}{|c|c|c|c|c|}
\hline & Positive & Negative & Non-significant & Total \\
\hline \multicolumn{5}{|l|}{ Democracy } \\
\hline effect sizes & 669 & 232 & 1146 & 2047 \\
\hline & $32.68 \%$ & $11.33 \%$ & $55.98 \%$ & \\
\hline study & & 19 & 124 & 188 \\
\hline & $23.94 \%$ & $10.11 \%$ & $65.96 \%$ & \\
\hline \multicolumn{5}{|l|}{ Human Capital } \\
\hline effect sizes & 333 & 26 & 516 & 875 \\
\hline & $38.06 \%$ & $2.97 \%$ & $58.97 \%$ & \\
\hline study & & 2 & 71 & 111 \\
\hline & $34.23 \%$ & $1.80 \%$ & $63.96 \%$ & \\
\hline \multicolumn{5}{|l|}{ Democracy (Reduced) } \\
\hline effect sizes & 180 & 144 & 440 & 764 \\
\hline & $23.56 \%$ & $18.85 \%$ & $57.59 \%$ & \\
\hline study & & 13 & 79 & 111 \\
\hline & $17.12 \%$ & $11.71 \%$ & $71.17 \%$ & \\
\hline \multicolumn{5}{|l|}{ Democracy (Main specifications) } \\
\hline effect sizes & 367 & 150 & 710 & 1227 \\
\hline & $29.91 \%$ & $12.22 \%$ & $57.86 \%$ & \\
\hline study & 44 & 19 & 117 & 180 \\
\hline & $24.44 \%$ & $10.56 \%$ & $65.00 \%$ & \\
\hline \multicolumn{5}{|l|}{ Democracy (Pre-DU) } \\
\hline effect sizes & 172 & 111 & 458 & 741 \\
\hline & $23.21 \%$ & $14.98 \%$ & $61.81 \%$ & \\
\hline study & 21 & 8 & 65 & 94 \\
\hline & $22.34 \%$ & $8.51 \%$ & $69.15 \%$ & \\
\hline \multicolumn{5}{|l|}{ Democracy (Post-DU) } \\
\hline effect sizes & 497 & 121 & 688 & 1306 \\
\hline & $38.06 \%$ & $9.26 \%$ & $52.68 \%$ & \\
\hline study & 24 & 11 & 59 & 94 \\
\hline & $25.53 \%$ & $11.70 \%$ & $62.77 \%$ & \\
\hline
\end{tabular}

Notes: The significance level is $\mathrm{p}<0.05$. The Reduced sample contains only estimates of democracy collected from a specification in which a proxy of human capital was included. The pre- $D U$ sample contains only estimates collected from studies published before December 2005 - the date in which the search for studies by Doucouliagos \& Ulubaşoğlu (2008) ended. The post-DU sample contains instead only estimates collected from studies published after December 2005. The main specifications sample contains only estimates collected from specifications included in the body of the article (i.e. appendixes are excluded) and not labelled as robustness tests, sensitivity analyses or falsification and/or placebo strategies. 
Figure C.1: Democracy, human capital and economic growth: T-statistic distributions comparison

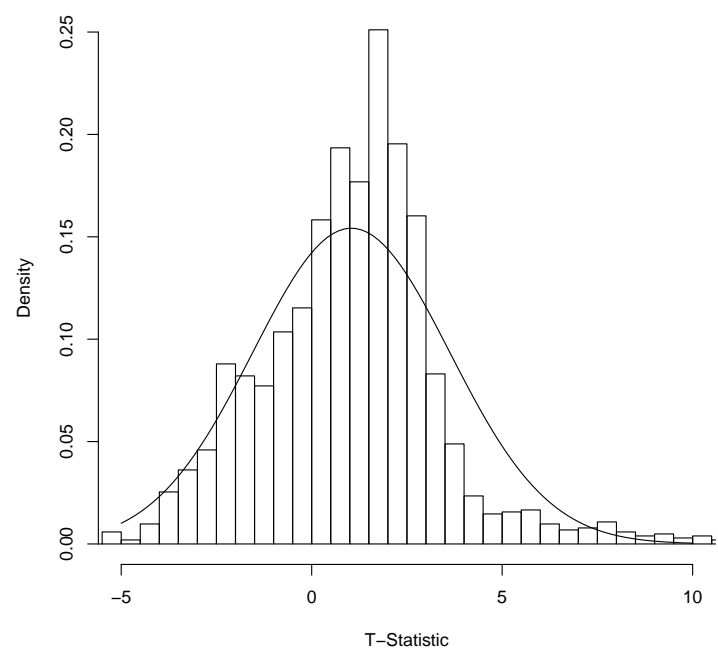

(a) Democracy and economic growth

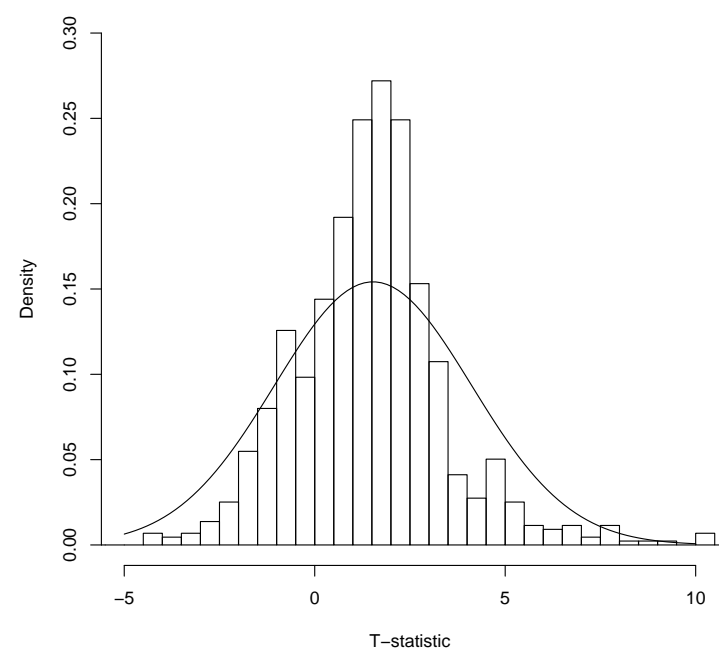

(b) Human capital and economic growth 
Figure C.2: Democracy and economic growth: raw partial correlation and Fisher z-transformation comparison

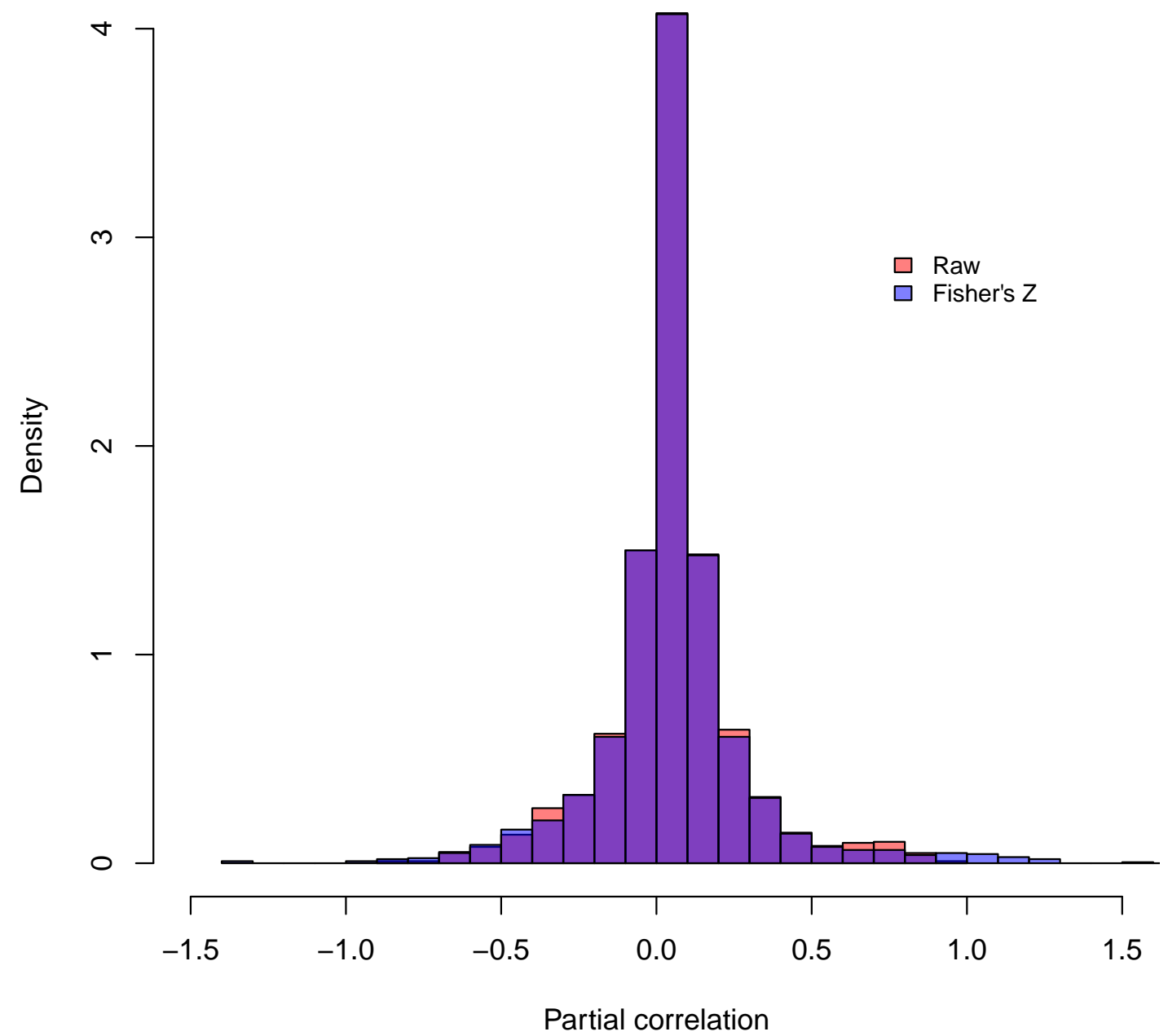

